UNIVERSIDAD NACIONAL DE LA PLATA

FACULTAD DE HUMANIDADES Y CIENCIAS DE LA EDUCACIÓN SECRETARÍA DE POSGRADO

\title{
LA LECTURA EN DOS CONTEXTOS DE ENSEÑANZA
}

Conocimiento sobre cuentos y enciclopedias en niños pequeños de escuelas públicas

\section{Cinthia Kuperman}

Tesis para optar por el grado de Magíster en Escritura y Alfabetización

Directora Ana María Kaufman

Universidad Nacional de La Plata

La Plata, Junio 2014 


\section{A Dany}

Por los guijarros que hemos dejado y recogido -codo a codo- para no perder-nos en el camino... 
A Ana María Kaufman, directora majestuosa, timonel indispensable para llegar a destino.

El honor de haber discutido cada idea y que esas ideas trajeran la historia contada en primera persona de los procesos, de la manera de pensar el aprendizaje y la enseñanza, es un condimento que no imaginé tener y agradezco haber vivido.

A las maestras y equipos directivos de las ocho escuelas que nos han abierto sus puertas para compartir su quehacer.

A todos los niños -más de 100- con los que hemos compartido largas jornadas de intercambio.

A Mirta Castedo quien creó y sostuvo (y lo sigue haciendo) esta Maestría donde el intercambio, la seriedad y el compromiso con la enseñanza dicen: PRESENTE.

También, agradezco su apoyo y generosidad intelectual.

A la maestra de maestras, Delia Lerner, quien desde el primer momento que la conocí abrió mis ojos y, desde ahí en más, enseñar tuvo otro sabor y color.

A María Elena Cuter y Mirta Torres por la complicidad, la confianza que han depositado en mí, por el acompañamiento, pero especialmente por dejar el fueguito sagrado siempre encendido en tantos y en mí, particularmente.

A Diana Grunfeld, compañera, amiga y compinche, sostén imprescindible en esta travesía.

A Ani Siro, oído poderoso y amiga entrañable.

A Jimena Dib y Romina Campopiano por la lectura atenta, generosa y compañera.

Y a todos aquellos que acompañaron este sinuoso e interesante proceso. 


\section{ÍNDICE}

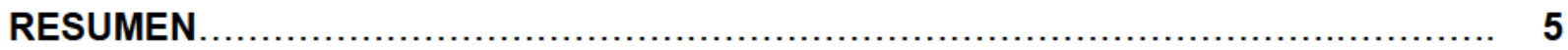

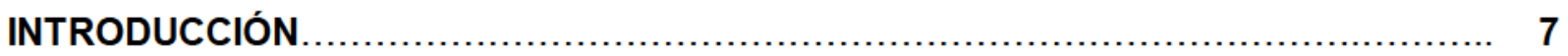

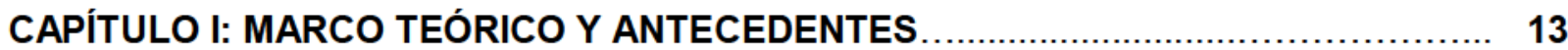

1.1. Algunos aspectos de la teoría de Jean Piaget........................................... 13

1.2. Teorías sobre la concepción de la lectura................................................ 15

1.3. Investigaciones psicogenéticas sobre la lectura.................................... 17

1.4. Conocimientos infantiles sobre el lenguaje escrito....................................... 19

1.5. Breve caracterización de diversos enfoques sobre la enseñanza de la lectura.... 20

1.6. Prácticas de enseñanza de la lectura orientadas por un marco constructivista... 24

1.7. Antecedentes relacionados con la búsqueda de información de libros.............. 28

CAPÍTULO II: OBJETIVOS Y PREGUNTAS DE INVESTIGACIÓN, HIPÓTESIS Y DISEÑO METODOLÓGICO 31

2.1. Objetivos y preguntas de investigación.......................................... 31

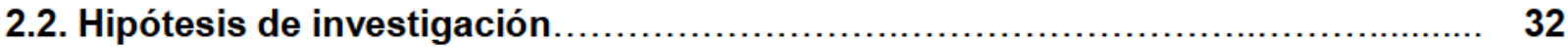

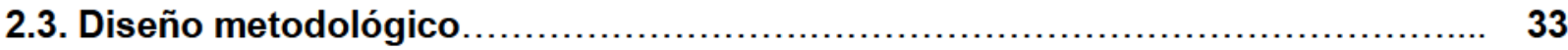

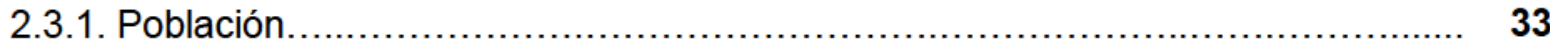

2.3.2. Caracterización de las propuestas didácticas de las Escuelas $X$ y Z $Z \ldots \ldots \ldots \ldots \ldots . . . . . .35$

2.3.2.1. Rasgos esenciales de las prácticas de enseñanza en los grupos X............. $\quad 36$

2.3.2.2. Rasgos esenciales de las prácticas de enseñanza en los grupos $Z$............. $\quad 37$

2.3.2.3. Cuadros comparativos .......................................................... 38

2.3.3. Situaciones experimentales de recolección de datos............................... 43

2.3.3.1. Descripción del material utilizado en las situaciones analizadas en la

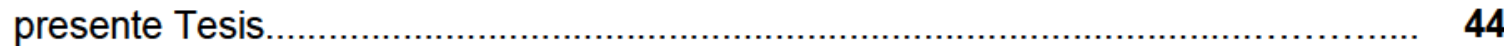

2.3.3.2. Situación 1: Identificar el libro "para saber más sobre las abejas" ............... $\quad 46$

2.3.3.3 Situación 2: Localizar información específica en una enciclopedia............... 47

CAPÍTULO III: IDENTIFICAR EL LIBRO “PARA SABER MÁS SOBRE LAS ABEJAS”.. 49

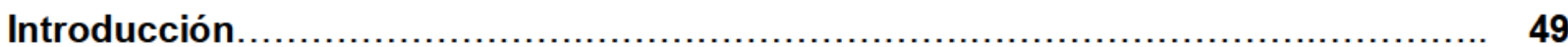

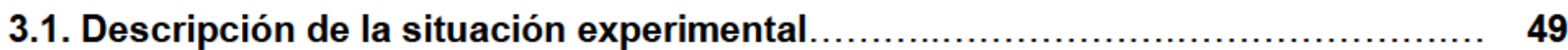

3.2. Descripción de los libros utilizados .................................................. 50

3.3. Elección del libro "para saber más sobre las abejas"............................ 51

3.3.1. Distribución de las respuestas en función de la elección del libro en el total de los niños estudiados

3.3.2. Distribución de las respuestas según nivel de escolaridad y tipo de escuelas a las que asisten $(\mathrm{X}$ y $\mathrm{Z})$ 
3.4. Justificaciones de la elección efectuada.

3.4.1. Selección de las respuestas para el análisis de las justificaciones.

3.4.2. Análisis de la distribución de los diferentes tipos de justificaciones de la elección efectuada.

56

3.4.2.1. Distribución en el total de los niños estudiados.

3.4.2.2. Distribución según nivel de escolaridad y de tipo de escuelas a las que asisten (X y Z).

3.4.3. Análisis de las verbalizaciones de los niños en cada una de las categorías descriptas

3.4.3.1. Justificaciones que sólo atienden a las ilustraciones.

3.4.3.2. Justificaciones que ponderan algunas características materiales de los libros.

3.4.3.3. Justificaciones que toman en cuenta ciertos rasgos específicos de los textos literarios y/o de los enciclopédicos

\section{CAPITULO IV: LOCALIZAR INFORMACIÓN ESPECÍFICA EN UNA}

ENCICLOPEDIA.

Introducción.

4.1. Descripción de la situación experimental.

4.2. Descripción del libro utilizado.

4.3. Análisis de las respuestas de los niños para localizar "dónde dice sobre las abejas

4.3.1. Comparación de las respuestas de los niños en la elección inicial y final.

4.4. Análisis de las respuestas de los niños a partir del contraejemplo del investigador.

4.4.1. Caracterización de las respuestas entre la localización inicial y la posterior al contraejemplo del investigador.

4.4.2. Distribución de los diferentes recorridos transitados por los niños.

4.4.3. Distribución de los recorridos según nivel de escolaridad

4.4.4. Distribución de los recorridos según el tipo de escuela a la que asisten.

4.4.5.1. Recorrido $A B+$ : niños que arriban a la página de las abejas y concluyen en ella a pesar del contraejemplo.

4.4.5.2. Recorrido AV+: niños que arriban a la página de las avispas y cambian de opinión culminando en la página de las abejas.

4. 4.5.3. Recorrido AB-: niños que arriban a la página de las abejas y cambian de opinión culminando en otra página. 
4.4.5.4. Recorrido AV-: niños que arriban a la página de las avispas y el contraejemplo no los hace cambiar de opinión............................................ 108

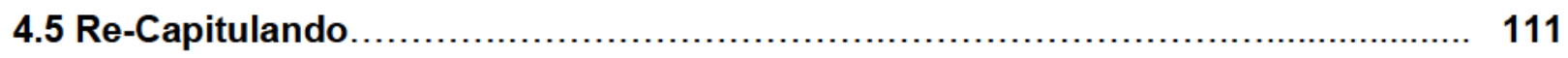

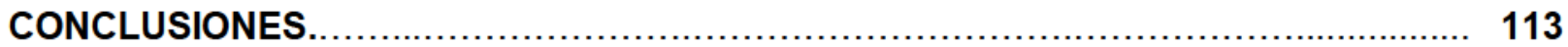

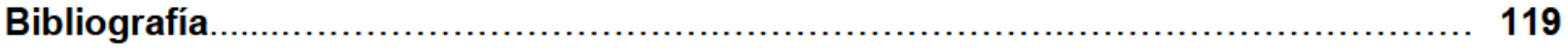

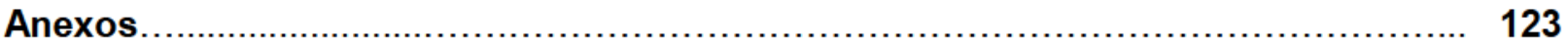

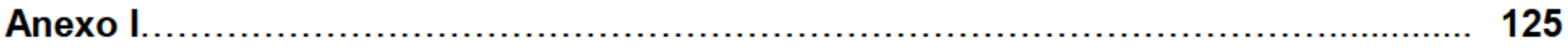

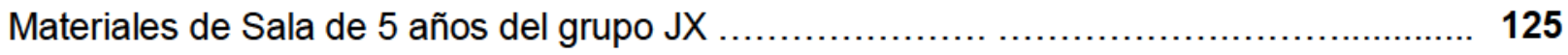

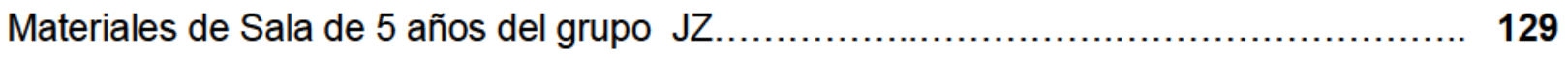

Materiales de Primer Grado del grupo PX..................................................... 131

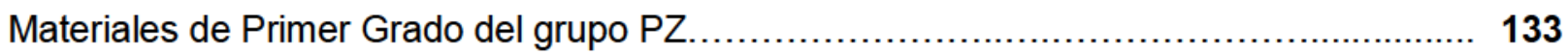

Anexo II - Copia de la enciclopedia utilizada .............................................. 137

Anexo III - Ejemplos de notas complementarias a la grabación de la situación $2 \ldots \ldots \ldots \ldots .139$ 



\section{LA LECTURA EN DOS CONTEXTOS DE ENSEÑANZA \\ Conocimiento sobre cuentos y enciclopedias \\ en niños pequeños de escuelas públicas}

\section{Resumen}

Este estudio compara semejanzas y diferencias entre respuestas de niños pertenecientes a familias con escaso contacto con los libros, que asisten a escuelas públicas en las que se desarrollan prácticas de enseñanza diferentes. Tales respuestas fueron obtenidas al finalizar el año escolar y corresponden a niños que se encuentran en distintos niveles de escolaridad (salas de 5 años de Jardín de Infantes y Primer Grado). El contexto familiar escasamente letrado de estos niños convierte a la escuela en un marco institucional crucial en su presente y futuro como ciudadanos plenos de la cultura escrita. Este estudio pone en primer plano dos prácticas de enseñanza que vehiculizan la alfabetización de estos niños en sentido amplio. El contraste entre ambas es el foco principal de análisis, a través de ciertos saberes sobre la lengua escrita que ponen en evidencia los niños entrevistados.

En el marco de una entrevista de tipo clínico-crítica se le presentan a cada niño dos libros de circulación social: una enciclopedia de animales y un cuento, ambos con imágenes de abejas en la tapa y se les pregunta cuál de los dos libros sería útil "para saber sobre las abejas". Luego se le solicita localizar información específica en la enciclopedia.

Esta Tesis se propone contribuir a los debates actuales acerca de los enfoques sobre la enseñanza de la lectura y la escritura a través de una mirada crítica sobre las prácticas docentes en vigencia en las aulas. 



\section{INTRODUCCIÓN}

Desde épocas muy antiguas la alfabetización escolar se realiza con dos superficies de escritura privilegiadas: el pizarrón reservado al maestro y las pizarras individuales -sustituidas luego por los cuadernos individuales- para los alumnos (Chartier, A.M. 2001). Los primeros libros que se introducen no son libros para leer sino "para aprender a leer" (oraciones estereotipadas con letras repetidas, secuencias de sílabas, palabras, frases, etc.). Estos libros para aprender a leer son una mezcla de ejercicios con algunas lecturas carentes de toda cualidad literaria, precisamente porque tratan de controlar las letras o sílabas ya enseñadas. Es, además, el mismo libro para todos los niños. En Argentina esto ocurre a partir de 1880 (Spregelburd, R. 2000).

Mucho más reciente es la tendencia a pasar de un libro único a una diversidad de libros presentes en la biblioteca de aula.

Los requerimientos de la alfabetización del siglo XXI no permiten postergar indefinidamente el acceso al objeto por excelencia de la cultura letrada: los libros de circulación social. La alfabetización necesaria en un mundo caracterizado por una enorme diversidad de escrituras que circulan por todos los medios (incluido Internet) hace difícil pensar que el pizarrón y el cuaderno predominantemente superficies escolares - puedan mantenerse "congelados", sin dar acceso a los niños a los libros. Un gran defecto de la concepción tradicional de la alfabetización es que posterga el acceso a la lengua escrita en cuanto tal.

Ser buen lector en la actualidad exige manejarse con autonomía y mirada crítica frente a la diversidad de soportes e información que están presentes en nuestra cultura. Frente a esa variedad y diversidad de información, localizar lo que se necesita es una tarea compleja que requiere de búsquedas guiadas siempre por propósitos determinados. Explorar, buscar, localizar, demanda a todo lector una modalidad particular: no leer de "punta a punta" desde el inicio hasta el final.

Ello conlleva a realizar diversas exploraciones que requerirán de descartes, lecturas más detenidas, comparación entre dos o más fuentes de información, o bien en el mismo ejemplar "ir y venir" entre las páginas hasta sentirse satisfecho de haber encontrado lo que se creía buscar. 
En las lecturas de tipo exploratorias se distinguen dos instancias: una para decidir qué materiales leer o consultar y la segunda destinada a localizar una información.

La primera incluye lecturas a "vuelo de pájaro": son las que se realizan para obtener una idea general del texto, para mirar por encima o "echar un vistazo" y permiten determinar si se ajusta o no a los propósitos que se persiguen. Esta modalidad es característica cuando se hojea un diario, cuando se busca información en textos de estudio, en enciclopedias, para buscar un libro entre varios, etc. En general, el lector que hace una lectura de reconocimiento se detiene en los títulos, en la tapa, en los datos que brinda la contratapa, en las diferencias tipográficas que pueda ofrecer el material en el índice temático, en los epígrafes de una ilustración o fotografía y en el resumen de las conclusiones. En la segunda instancia, las lecturas tienen como propósito ubicar información específica, y se caracterizan porque en ellas predomina un rastreo sistemático para encontrar una referencia particular dentro de un cúmulo de datos. Esta lectura de reconocimiento tiene sentido cuando se quiere encontrar un dato particular en un índice, un término específico en una página, etc. (Perelman; 2011).

Ambas modalidades de lectura se complementan. Acceder a lo que se pretende encontrar demanda sucesivas coordinaciones de informaciones diversas.

Los buenos lectores son exploradores experimentados y, al hojear y observar las propiedades de los textos impresos, saben qué sectores son relevantes para tomar ciertas decisiones. La interacción sistemática con diversos materiales escritos permite identificar la especificidad de cada portador y es posible advertir cómo se organiza la información: por temas, por orden alfabético, orden cronológico, la presencia de un índice, de titulares destacados o epígrafes, de imágenes, etcétera (Torres; 2001).

Los niños pequeños y aquellas personas que no tienen un contacto frecuente con materiales escritos desconocen la organización canoníca y estandarizada de los libros que les permita anticipar y encontrar o desechar rápidamente el material que tienen en sus manos en función del o los propósitos que se persiguen.

Estas prácticas son esenciales para cualquier lector, sin embargo se enseñan escasamente en la escuela y su presencia es casi ausente en los primeros años de escolaridad.

En las últimas décadas, numerosas investigaciones dan cuenta de que los niños desde muy pequeños interpretan los textos antes de leer convencionalmente poniendo en juego diversas estrategias lectoras. 
La presente Tesis $^{1}$ se propone analizar qué saben los niños pequeños sobre libros de géneros distintos e indagar qué procedimientos ponen en juego para localizar una información específica en un texto informativo cuando la situación demanda un análisis cuidadoso de indicadores gráficos y textuales. También es relevante comprobar la estabilidad de sus respuestas que se manifiesta cuando los niños sostienen su elección o la modifican en función del contraejemplo que propone el investigador.

El objetivo principal es contrastar las respuestas de niños que se encuentran culminando el Nivel Inicial y Primer Grado de la escuela primaria y que asisten a instituciones con prácticas de enseñanza diferentes.

Para ello, se seleccionaron niños de cuatro Jardines de Infantes y cuatro Primeros Grados de escuelas públicas pertenecientes a tres jurisdicciones - CABA, Provincia de Buenos Aires y General Cabrera, Córdoba - a las que asisten poblaciones de bajos recursos socio- económicos. Los padres han asistido a la escuela primaria y en su mayoría han completado sólo ese nivel de escolaridad formal.

Optamos por niños de sectores urbanos con muy pocas posibilidades de acceso al contacto asiduo con diversidad de libros de circulación social y lecturas desde sus hogares. Esta decisión se tomó porque la influencia de las prácticas escolares es decisiva en este sector de la población mientras que en otros, con mayores oportunidades de interacción con los libros, es más difícil deslindar la influencia del hogar de la influencia escolar en la alfabetización de los alumnos.

Respecto de la caracterización de los docentes, nos interesaba contrastar propuestas de enseñanza a cargo de maestras igualmente comprometidas con el aprendizaje de sus alumnos e igualmente convencidas de las bondades de la propuesta didáctica utilizada. Por lo tanto, el diseño elegido coloca la variable "docente" en igualdad de condiciones, es decir, las mejores condiciones posibles para cada una de las propuestas didácticas. Este punto es abordado de manera más pormenorizada en el Capítulo II.

Se diseñaron situaciones potencialmente aptas -las mismas tareas tanto en Salas de cinco años y en Primer Grado- para poner de manifiesto las ideas de los niños en el marco de entrevistas de

\footnotetext{
${ }^{1}$ En sus inicios, esta Tesis formó parte de un proyecto más amplio dirigido por la Dra. Emilia Ferreiro y codirigido por la Mg. Claudia Molinari. El objeto de estudio, el diseño experimental y los primeros análisis estuvieron bajo la dirección de ambas a quienes agradezco el tiempo, el intercambio y el trabajo compartido.

La tarea de recolección de datos fue compartida con Diana Grunfeld, Claudia Petrone y Gabriela Zucalá.
} 
tipo clínico-críticas al finalizar el año escolar. A partir de ellas hemos podido analizar la diversidad de respuestas ante las mismas tareas planteadas como así también las estrategias de resolución utilizadas para arribar a ellas. Eso permitió observar el impacto que las prácticas escolares han podido tener en sus aprendizajes.

Todas las escuelas contaban con biblioteca institucional. No obstante, su uso y las propuestas de trabajo en torno a los libros, a la lectura y a la escritura eran disímiles. Cuatro de las escuelas (dos Jardines y dos Primeros Grados) desarrollaban prácticas de enseñanza que podríamos identificar como "usuales" o "tradicionales", basadas en el desarrollo de un conjunto de habilidades perceptivo-motrices y enseñanza graduada de letras. Las identificamos como grupo $X$ y se denominarán, de aquí en adelante, Jardines $X$ (JX) y Primero X (PX).

Las otras cuatro (dos Jardines y dos Primeros Grados) desarrollaban prácticas que podríamos caracterizar como "constructivistas". Las identificamos como grupo Z y se denominarán, de aquí en adelante, Jardines $Z(\mathrm{JZ})$ y Primero $\mathrm{Z}(\mathrm{PZ})$.

Nos interesa verificar si existen diferencias entre los grupos que han participado en prácticas de enseñanza disímiles (Escuelas $X$ y Escuelas Z), como así entre distintos niveles de escolaridad (salas de 5 años de Jardín y Primer Grado).

El fracaso escolar sigue ocupando un lugar en la agenda educativa. Es necesario seguir investigando y reflexionando para buscar alternativas que permitan que todos puedan ejercer su derecho ciudadano de ser partícipes conscientes y activos de la época que les toca vivir. Y eso requiere poder manejarse en el mundo de la información en soportes diversos, participar de situaciones de lectura y de escritura desde muy pequeños para formar parte de una verdadera comunidad de lectores. Jean Hébrard menciona que la escuela puede "crear una comunidad de interpretación: lo importante no es solo dar libros a los niños, sino que aprendan que no hay lecturas fuera de las comunidades. El placer está dado por la palabra que se agrega al libro²."

\footnotetext{
2 Jean Hébrard (2007): Conferencia dictada en Buenos Aires.
} 
Esta Tesis está organizada en 4 capítulos:

En el Capítulo I, se describe el marco teórico y los antecedentes más relevantes para abordar esta investigación.

El Capítulo II, se especifican los objetivos de estudio, las hipótesis, se presenta el diseño metodológico donde se describe la población, el contraste entre las propuestas de enseñanza y las tareas que se han administrado a los niños.

En el Capítulo III, se analiza cómo los niños -de salas de 5 años y Primer Grado al finalizar el año lectivo- identifican el libro "para saber más sobre las abejas" entre una enciclopedia y un cuento, ambos con imágenes de abejas en la tapa.

En el Capítulo IV, se indaga de qué manera los niños localizan información específica en la enciclopedia y si logran sostener su elección inicial luego del contraejemplo del investigador.

Finalmente, se presentan las Conclusiones del trabajo. 



\section{CAPÍTULO I \\ MARCO TEÓRICO Y ANTECEDENTES}

En este capítulo nos proponemos presentar el marco teórico desde el cual se interpretan y analizan los datos y los antecedentes específicos referidos a los estudios vinculados con los objetivos de este estudio.

\subsection{Algunos aspectos de la teoría de Jean Piaget}

Esta investigación está sustentada por un marco teórico constructivista que considera que el conocimiento se construye en interacción con el objeto. En ese sentido, la teoría de Jean Piaget ocupa un lugar central en este escenario. Mencionaremos solo algunos puntos esenciales que son pertinentes para este trabajo.

La teoría piagetiana es una teoría general de los procesos de adquisición del conocimiento, un marco de referencia teórica que permite comprender los procesos de adquisición de conocimientos. La concepción de aprendizaje tiene como premisa "dar cuenta del pasaje de una estructura a otra, es decir, explicitar el mecanismo formador" (Castorina y otros; 1997: 45). Desde el punto de vista del niño, los objetos adquieren significado en la medida en que son asimilados a sus esquemas de acción y se acomodan simultáneamente a las características del objeto. Si el objeto se torna imprescindible para el ejercicio de la acción, ésta le otorga significado al modificarlo. Esta doble relación entre asimilación y acomodación es lo que en esta teoría se conoce como "equilibrio".

Los estudios de Piaget han puesto en evidencia qué tipo de respuestas tiene el sujeto ante una situación que tiene la potencialidad de ser perturbadora y, por lo tanto, "se ha convertido, por este solo hecho, en perturbable; se trata más bien de consolidarla y, por lo tanto, de completarla o mejorarla" (Piaget; 1981: 23). Los sujetos pueden tener una reacción alfa y por lo tanto neutralizar la perturbación o beta, cuando advierten el conflicto planteado pero todavía no pueden encontrar la respuesta en el interior del sistema y brindan una solución de compromiso, o bien, arribar a una respuesta gama cuando logran un equilibrio dado que integran el sistema total, en tanto evidencia un pasaje de nivel de conocimiento. En estos tres casos afirma Piaget que el equilibrio es "incrementante" y, por lo tanto, constructivo. 
El método clínico-crítico que caracteriza a esta teoría permite conocer el pensamiento de los sujetos. La indagación clínica es el procedimiento privilegiado para acceder a la organización intelectual en la investigación. Implica una relación dialéctica entre entrevistador y entrevistado, que permite aprehender las ideas de los niños. En el transcurso de las entrevistas se suceden momentos en los que suelen formularse tres tipos de preguntas: de exploración, de justificación y de control o de contra argumentación.

Las preguntas de exploración tienden a develar la noción cuya existencia y estructuración se busca. Las preguntas de justificación obligan al niño a legitimar su punto de vista. Las preguntas las de control buscan la coherencia o contradicción de las respuesta a través de la contra argumentación. Ésta tiene una significación especial, el interrogador plantea al niño una sistemática discusión con el propósito de establecer si las adquisiciones son o no estables, es decir, cuál es el grado de equilibrio de sus acciones ante los problemas. La necesidad en la argumentación infantil es reveladora de un alto grado de equilibrio en la sistematización de sus acciones. Por el contrario, otro tipo de resistencia a la contra argumentación indica que en el nivel en que se encuentra el niño, el contraejemplo no constituye para él una situación problemática (Castorina, y otros; 1997).

El sujeto en esta teoría es considerado un sujeto cognoscente que busca activamente tratar de conocer el mundo que lo rodea y de resolver lo que ese mundo le plantea. Es un sujeto que aprende, básicamente, a través de sus acciones sobre los objetos del mundo y que construye categorías de pensamiento propias, al mismo tiempo que organiza el mundo. Un sujeto activo compara, excluye, ordena, comprueba, reorganiza, formula hipótesis etc. en acción interiorizada o en acción efectiva (según su nivel de desarrollo). Ningún aprendizaje conoce un punto de partida absoluto, por nuevo que sea el contenido a tratar éste deberá ser asimilado por el sujeto según sus esquemas de asimilación que tratan de interpretarlo.

La noción de error cobra un sentido particular en esta perspectiva. El conocimiento requiere de grandes reconstrucciones globales algunas de las cuales son erróneas respecto al punto de llegada, pero constructivas. Los errores sistemáticos son estudiados para tratar de comprenderlos. En este marco explicativo, los errores son interpretados de manera peculiar. Ciertos errores en las respuestas infantiles permiten entender la lógica de sus sistemas de ideas, lo cual lleva a hablar de los errores constructivos como "respuestas que se apartan de las respuestas correctas, pero que lejos de impedir alcanzar estas últimas parecieran permitir los logros posteriores" (Ferreiro y Teberosky, 1979: 35). 


\subsection{Teorías sobre la concepción de la lectura}

En las primeras décadas del siglo XX los trabajos de Huey (1908) y Thorndike (1917) señalan la complejidad de la lectura como proceso psicológico e intentan - con sus estudios - dar solución a los problemas derivados del aprendizaje de la lectura, especialmente en la etapa inicial de la adquisición. La concepción de la lectura entendida como un conjunto de habilidades secuenciadas propone el reconocimiento de palabras como el primer nivel de la lectura, seguido de la comprensión como segundo nivel, la reacción o respuesta emocional como tercer nivel y el de la asimilación o evaluación como final. Desde esta perspectiva, el lector comprende un texto cuando es capaz de extraer el significado que este le ofrece (Dubois, 2005; Goodman, K.; 1982) desempeñando un papel meramente receptivo en tanto el sentido de lo leído le llega de afuera.

En la década de los sesenta, a partir del avance de la psicolingüística y de la psicología cognoscitiva, otras investigaciones tuvieron auge. En la literatura sobre el tema se lo denomina enfoque interactivo de la lectura. Este modelo supone una síntesis y una integración de otros dos enfoques que han explicado el proceso de la lectura: los modelos jerárquicos ascendente (bottom up) y descendente (top down). En el primero se considera que el lector, ante el texto, procesa sus elementos comenzando por las letras, continuando por las palabras y, finalmente, las frases. Es un proceso secuencial jerárquico que condice con la comprensión del texto. El lector comprende el texto porque logra decodificarlo en su totalidad. Este modelo está centrado en el texto. Algunos de sus representantes fueron: Gough, 1972 y Laberge y Samuels, 1974.

En el segundo modelo (descendente), se sostiene lo contrario. El lector no procede letra por letra, sino que hace uso de su conocimiento previo y de sus recursos cognitivos para establecer anticipaciones sobre el contenido del texto y se apoya en este conocimiento para verificarlas. El proceso de lectura es secuencial y jerárquico pero descendente: a partir de las hipótesis y anticipaciones previas, el texto es procesado para su verificación (Solé, 1999).

El modelo interactivo, no se centra exclusivamente ni en el texto ni en el lector. El lector utiliza simultáneamente su conocimiento del mundo y su conocimiento del texto para construir una interpretación acerca de este último.

Siguiendo esta línea de interpretación, Frank Smith (1980), sostiene que la lectura es un proceso selectivo en el cual el lector no utiliza toda la información disponible, sino tan sólo la que necesita para construir el significado del texto. En todo acto de lectura, se hace uso de una información visual y de una información no visual en la que se incluye tanto el conocimiento del tema como el conocimiento lingüístico del lector. La información visual es provista por la organización de las letras en la página impresa o manuscrita, pero la información no visual es aportada por el lector mismo. 
Kenneth Goodman en El desarrollo de la escritura en niños muy pequeños interpreta a la lectura como un proceso psicolingüístico en el que interactúan pensamiento y lenguaje. Sin significado no hay lectura. Toda lectura es interpretación y lo que el lector es capaz de comprender y de aprender a través de la lectura depende fuertemente de lo que el lector conoce y cree antes del acto de leer. Este autor considera que diferentes personas que leen un mismo texto lo interpretarán en función de lo que conocen y, por esa razón, pueden llegar a otorgarle diferentes significados. Goodman (1994) menciona diferentes estrategias que un lector pone en juego para la construcción del significado de un texto: muestreo, predicción, inferencia y autocorrección. El lector construye un texto paralelo y estrechamente relacionado con el texto editado, pero no idéntico al que el autor tenía en mente. Entre el lector y el texto se da un proceso de transacción a través del cual ambos se transforman. Los estudios de Kenneth Goodman se basan en las respuestas incorrectas o desaciertos: "miscues", realizadas por los lectores cuando leen, fundados en pistas que el texto provee. Sus afirmaciones son el resultado de varias décadas de investigación en las que, junto a otros -como Yetta Goodman, Donald Graves, Lucy Mc Calkins, Louise Rosenblatt y Frank Smith-, desarrollaron indagaciones analizando los "miscues" ("variaciones" de los niños al leer en voz alta, fundados en pistas que el texto provee) y aplicando el procedimiento "cloze" (una técnica para examinar el proceso de comprensión).

El movimiento se conoce con el nombre de Whole Lenguage (WL) o Lenguaje Integral asumiendo como idea básica que todo el lenguaje es "integral", apartándose así del modelo de instrucción aislada en habilidades específicas.

En su libro El proceso de lectura María Eugenia Dubois (2005), manifiesta que un paso más en la interpretación de los procesos de lectura es la concepción que proviene de la teoría literaria desarrollada especialmente por Louise Rosenblatt quien enfatiza la dinámica del proceso de lectura, en el cual lector y texto se confunden en un mismo tiempo y surgen transformados. La autora entiende este proceso como una transacción, ya que se produce una relación recíproca entre el lector y el texto, un suceso particular en el tiempo donde el lector adquiere su carácter de tal en virtud del acto de lectura y es a través de éste que el texto adquiere significación. En el modelo denominado "sociopsicolingüístico transaccional" se explican las claves del sistema lingüístico que los lectores ponen en juego para construir significado (grafofónicas, léxico gramaticales, semántico-pragmáticas) y el empleo de diversas estrategias.

A finales del siglo XX, varios autores consideran a la lectura como proceso de comprensión crítica esta perspectiva para referirse a la lectura desde una mirada sociocultural (Gee, 1990; Zavala, 2002). Desde esta perspectiva se asume que la escritura es una "forma cultural" y un "producto social" -como cualquier otra tecnología- de modo que el único modo de investigarla es prestando 
atención a la comunidad en la que ha surgido, atendiendo al conjunto de los elementos del contexto social.

(...) El acto de leer y de elaborar un significado varía según el discurso, la disciplina y el contexto. En cada ámbito o esfera de la comunidad se han desarrollado históricamente formas particulares de transmitir e inferir significados, que la personas aprendemos al mismo tiempo que participamos de la actividad (Cassany, 2000: 7).

\subsection{Investigaciones psicogenéticas sobre la lectura}

Desde un marco teórico piagetiano, las investigaciones psicogenéticas de Emilia Ferreiro y Ana Teberosky (1979) pusieron de manifiesto que el proceso por el cual se construyen las bases para la apropiación de la lengua escrita y el desarrollo de la lectura comienza mucho antes de que los niños ingresen a la escuela primaria. Estas investigaciones explican y desarrollan cómo los niños construyen ideas originales, lógicas y sistemáticas sobre la escritura y las ponen en acción cuando intentan interpretar la escritura y cuando producirla. Desde esta perspectiva se estudia cómo piensan los niños para hacer una teoría sobre su competencia y no de su desempeño considerando su evolución desde un punto de vista constructivista.

Desde este marco el acto de lectura se concibe como un proceso de coordinación de informaciones de diversa procedencia con todos los aspectos inferenciales que ello supone. Esos procesos de coordinación tienen una historia evolutiva. Desde esta perspectiva se parte de lo que los niños saben y no de lo que ellos ignoran. Será en la interacción con la lengua escrita que podrán ir ajustando las conceptualizaciones. Investigaciones diversas (Ferreiro y Teberosky, 1979; Ferreiro: 1975, 1976, 1982, 1988, 1997) arrojan datos fundamentales para comprender cómo los niños que aún no saben leer de manera convencional pueden interpretar textos que rodean su entorno antes de ser capaces de leerlos. Antes de su ingreso a la escuela primaria son capaces de elaborar criterios sobre las características formales de un texto, que manifiestan en términos de lo que es "legible/no legible". Un texto "sirve para leer" desde el punto de vista del niño, si posee una determinada cantidad de grafías (mínimo dos y de preferencia tres) y si presenta variedad en la secuencia de grafías (Ferreiro, 1978; Ferreiro y Teberosky, 1979; Teberosky, 1984).

Desde esta perspectiva, la atribución de significado es constitutiva de todo acto de lectura. El acto de lectura no es concebido como adición de informaciones (información visual más información no visual) sino como un proceso de coordinación de informaciones de diversa procedencia y su objetivo principal es la obtención de significado expresado lingüísticamente. Ferrerio y Teberosky (1979) consideran que a la lista de informaciones no visuales utilizadas por Smith (1980) hay que agregarle la identificación del soporte material del texto. "Aún antes de que comencemos a leer ya 
sabemos (por anticipación) algo sobre el texto, en virtud de la categorización que hayamos hecho del soporte material". (Ferreiro y Teberosky, 1979: 346). Por ejemplo, si identificamos el soporte como un libro de información, ya se sabe que algunas construcciones no aparecerán allí, como por ejemplo "había una vez". Esta perspectiva considera esencial el bagaje interpretativo que trae consigo el niño, quien intenta comprender los diversos textos que circulan socialmente mucho antes de ser capaz de leer convencionalmente (Ferreiro, 1986).

Otros estudios dirigidos por esta investigadora (Ferreiro, 1986) han considerado datos longitudinales sobre cómo los niños interpretan los textos antes de leer convencionalmente los cuales pusieron de manifiesto la evolución de las ideas infantiles. Una de las primeras hipótesis que los niños elaboran, cuando comienzan a indagar sobre "lo que las letras pueden decir", (Ferreiro, 1997:86) es que éstas representan el nombre de los objetos. Frente a un libro con imágenes, los pequeños consideran que las letras dicen el nombre de los objetos dibujados. Esta "hipótesis del nombre" sigue vigente por cierto tiempo. Incluso los niños aceptan el desplazamiento de la misma escritura considerando que el significado va a variar en función de la imagen a la que vaya acompañando. Posteriormente, los niños logran un paso más hacia la conservación del significado que atribuyen a un texto, lo que les permite entender la estabilidad de la escritura.

Paulatinamente, los niños logran tomar en consideración ciertas características o propiedades del texto para acceder a su interpretación. Si bien esta interpretación continúa basándose en la hipótesis del nombre, el reconocimiento de propiedades cuantitativas del texto, en un principio, y cualitativas después - utilización de "letras índice" -, permiten paulatinamente ajustar sus interpretaciones. (Ferreiro, 1997).

La escritura se concibe como un sistema de marcas, social y culturalmente construido. Este sistema es comprendido como un sistema de representación del lenguaje y no como un código de transcripción entre unidades sonoras y gráficas. La escritura no es concebida como mero reflejo de la oralidad en la que ya están predeterminados tanto los elementos como las relaciones, por lo cual, escribir supondría convertir las unidades sonoras en unidades gráficas. Por el contrario, se la concibe como un sistema de representación en el que ni los elementos ni las relaciones están predeterminados sino que la construcción de ese sistema responden a un largo proceso histórico y el problema central será comprender la naturaleza de ese sistema para reconstruirlo. En ese proceso de reconstrucción opera una relación dialéctica y no lineal entre la oralidad y la escritura (Ferreiro, 1980). No desarrollamos en este trabajo los diferentes niveles de adquisición del sistema de escritura, que han tenido gran difusión en el ámbito educativo, dado que el mismo está centrado en los procesos de lectura. 
Los saberes construidos por los niños con anterioridad a la escolaridad difieren en función de las prácticas específicas de lectura y escritura que hayan tenido. Además difieren de la oportunidad de interactuar con materiales impresos diversos y de los propósitos con se hayan realizado. Como señala Emilia Ferreiro (1997: 129): "Es probablemente a través de una amplia y sostenida participación en esta clase de situaciones como el niño llega a comprender por qué la escritura es tan importante en la sociedad".

\subsection{Conocimientos infantiles sobre el lenguaje escrito}

Los conocimientos infantiles acerca de las particularidades del lenguaje escrito también comienzan a construirse mucho antes de que los niños ingresen a primer grado. Cuando Claire Blanche-Benveniste (1982) define al "lenguaje que se escribe", hace referencia a un lenguaje más formal que el coloquial e incluye las variedades discursivas que forman parte de ese lenguaje. Es decir, un lenguaje que por su uso social es esperable encontrar de manera escrita y que por ciertas características lingüísticas denota una diferenciación textual tal como ocurre con el lenguaje de las noticias, de los cuentos, de las notas de enciclopedia, etc.

Diversas investigaciones psicogenéticas han aportado información relevante sobre las posibilidades infantiles de apropiarse del lenguaje escrito. Los niños que pertenecen a familias en cuyos hogares se realizan habitualmente actividades de lectura y escritura manifiestan de manera temprana un considerable dominio de las diferentes variedades discursivas. Pueden reproducir narraciones y poesías leídas previamente por los adultos en voz alta e incluso escribirlas por sí mismos con los recursos textuales y las formas gráficas de compaginación propias de los textos. (Teberosky; 1982; 2003; Ferreiro, Pontecorvo, Ribeiro y Gacía Hidalgo, 1996; Pontecorvo, 1998). Así también se evidencia que los niños logran diferenciar las maneras del decir de diferentes géneros (Ferreiro, 2007; Benveniste, 1982).

Según Teberosky (1995), el conocimiento sobre los géneros es uno de los saberes sobre el uso del lenguaje, influidos por las experiencias culturales con diversas situaciones comunicativas que requieren, además del conocimiento letrado, el necesario contacto con textos escritos. A partir del análisis de reescrituras de cuentos, noticias periodísticas y cartas de niños entre 6 y 7 años, la autora muestra que sus autores ya poseen conocimientos sobre el género y sobre el lenguaje que se escribe, ya que resguardan no sólo el texto modelo sino que también respetan formas textuales propias de esos géneros. Evidentemente, esas ideas acerca de lo escrito, son huellas de lo que se ha leído o escuchado leer. Liliana Tolchinsky (1993) también realizó interesantes investigaciones pioneras vinculadas con el conocimiento de los niños acerca del lenguaje escrito.

En experiencias de lectura de cuentos, los participantes se vinculan con estructuras complejas que favorecen el desarrollo lingüístico de los niños. Nelson (1984), Snow (1983) y Bus y Van 
ljzendoorn (1995) ponen de manifiesto que la interacción per se no explica estos progresos sino determinadas estrategias en esa interacción. Asimismo, en estudios psicológicos, Bruner (1988) sostiene que existen dos modos diferentes de pensamiento - $y$ dos géneros- uno narrativo y otro no narrativo "un buen relato y un argumento bien construidos son clases naturales diferentes (...) es el criterio de plausibilidad o veracidad que caracteriza la narración, mientras que es el criterio de verdad y de no contradicción el que orienta la explicación y la argumentación científica. (Bruner, citado en Teberosky, 1995: 103).

Por el hecho de participar en situaciones de lectura y escritura, los niños parecen ser capaces de anticipar algunas de las formas del lenguaje escrito en la propia cultura y entender a la escritura como organizada y sistemática (Clay, 1966; Teale y Sulzby, 1986; Goodman Y.,1982; Goodman Y., 1992; Harste y Burke, 1982). Según estos autores, las numerosas experiencias con el "lenguaje que se escribe" proveen significados y opciones semánticas que permiten a los niños anticipar el contenido de los textos que circulan en su entorno. La lectura sistemática de cuentos por parte del adulto promueve la construcción de estos conocimientos (Irwin, 1960; Cazden, 1965).

Las investigaciones citadas constituyeron una referencia relevante para poder analizar la manera en que los niños en la presente investigación resuelven una tarea en la que deben seleccionar entre un libro de cuentos y una enciclopedia para localizar información sobre un tema particular en el caso de que se quiera o necesite "saber más sobre las abejas".

\subsection{Breve caracterización de diversos enfoques sobre la enseñanza de la lectura}

Tradicionalmente, la enseñanza la lectura -también de la escritura- ha sido planteada como un problema de métodos: la búsqueda del método "más eficaz".

A lo largo de la historia, fueron sucediéndose métodos sintéticos que establecen como punto de partida las correspondencias entre lo oral y lo escrito, entre sonido y grafía en un proceso que va de las unidades letras al todo palabra - oración, métodos analíticos, que parten de la palabra y unidades mayores, procediendo luego a descomponer la palabra en unidades menores y métodos denominados analítico-sintéticos, muy difundidos en nuestro país bajo la forma del método de palabra generadora, que presenta una palabra, luego sus sílabas y finalmente sus fonemas, para volver luego a la palabra.

En Estados Unidos, en las primeras décadas del siglo XX, surgía una tecnología al servicio de la lectura, centrada alrededor del lector principiante que consistía en materiales graduados comenzando con ejercicios de preparación en el preescolar y primer grado, se focalizaba en 
vocabulario controlado, se introducían pocas palabras por vez. Los libros que circulaban estaban relacionados con ejercicios para practicar habilidades y proveer ejercicios con palabras. $\mathrm{K}$. Goodman (1982: 15) comenta que "Las lecturas se dividian según el desarrollo con una progresión normal y lecturas remediales". Aprender a leer fue considerado como el dominio de la habilidad para reconocer palabras y adquirir un vocabulario de palabras visualizadas.

Esta visión de la lectura impactó también en los países de la región y Argentina entre ellos. El eje estaba puesto en el análisis auditivo para aislar los sonidos (letras-sonido) y se planteaban dos cuestiones previas: 1) la pronunciación debía ser correcta, 2) las grafías de forma próxima debían enseñarse separadamente para evitar confusiones. También era necesario presentar un par por vez de grafemas-fonemas sin pasar al siguiente hasta que ése no estuviera bien fijado.

El aprendizaje, desde el inicio, requería aprender la mecánica de la lectura, es decir, descifrar el texto. Eso permitiría, luego, una lectura comprensiva de ése texto y estos pasos culminaban con la lectura expresiva donde la entonación ocupaba un lugar primordial. La escritura se concebía como una transcripción grafica del lenguaje oral y la lectura equivalía a decodificar lo escrito en sonido. Como en ningún sistema de escritura existe una relación absolutamente biunívoca entre la ortografía y el habla, se comenzaba por los casos de ortografía regular y se realizaron cartillas y libros hechos especialmente para este fin en la escuela primaria. En preescolar se proponían tareas de motricidad, discriminación visual, de organización espacial y temporal. Analizando las teorías sobre la alfabetización, Castedo y Torres (2011: 88) comentan que, en la región, estas prácticas son conocidas con el nombre de "aprestamiento", "prontidão" o "reading readiness", "preparación para" la lectura o "la disposición o nivel mínimo para sacar provecho de la instrucción en lectura, para comenzar a enseñar."

Berta Braslavsky (2000), al analizar Documentos Curriculares de las décadas del 70 y 80 , observa que la alfabetización, ligada a estos ejercicios, se inicia en la sección de cinco años con una serie de actividades que deben ser realizadas en un tiempo específico. Estas actividades se continuaban en primer grado.

Así como en sala de cinco años se institucionalizó el cuadernillo de aprestamiento, en primer grado fue el libro de lectura el eje de la enseñanza en esta área. Estos libros se confeccionaban sobre la base de los contenidos comunes y durante mucho tiempo estuvieron bajo la supervisión del Estado (Wainerman y Heredia, 1999). Las autoras citan una circular del Ministerio de Educación de la Provincia de Buenos Aires.

"El libro de texto, en primer lugar, es un material educativo por cuanto ofrece recursos y medios que ayudan a realizar los cambios conductuales que deben operarse en el educando 
(...) Por su especialización, amplitud, versatilidad, ocupa el primer lugar y es el soporte principal de la actividad humana". (En: Wainerman y Heredia; 1999:34)

Más allá del método de que se trate o si se ha puesto el acento en lo auditivo o en lo visual, en todos los casos se descuidan varios aspectos importantes: la competencia lingüística del niño y sus capacidades cognoscitivas (Ferreiro; Teberosky; 1979). Kaufman (1997) agrega que esta visión del aprendizaje de la lectura y la escritura considera que el maestro y el método constituyen el eje primordial, que leer y escribir involucra aspectos perceptivos y que comienza cuando los niños ingresan la escuela primaria.

En la década de 1960, el movimiento WL enfatiza el uso de estrategias de enseñanza utilizadas en contextos significativos y pone el énfasis en la lectura del adulto "tal como se hace en el hogar", las bibliotecas de aula y los libros verdaderos por sobre los "libros escolares". La atención a las unidades menores (la segmentación del lenguaje en partes, incluidos los fonemas) aparece en el contexto de las mismas prácticas de lectura y escritura y al servicio de las necesidades de los alumnos para lograr extraer sentido de los textos o para producir escrituras.

Las situaciones de enseñanza coherentes con esta perspectiva, resguardan el sentido social de la lectura y la escritura. Esta postura se posiciona contra la norma fija y reivindica la variabilidad del lenguaje, de allí que considere que el error es parte del aprendizaje, y la diversidad lingüística, una fuente de enriquecimiento y conocimiento. Dice K. Goodman: "los maestros del lenguaje integral tratan las partes del lenguaje -letras, sonidos, frases, oraciones- en forma integrada en el contexto real de uso del lenguaje". Tal atención no supone, en esta perspectiva, "obligar a los niños a analizarlo como lo haría un lingüista" (1990:9).

El lenguaje integral también enfatizó la idea de que los niños aprendían a leer por inmersión en un ambiente rico en materiales escritos, en el contacto intenso y temprano con textos y desarrollando actividades de lectura. (Chall, Jacobs y Baldwin, 1990; Smith, 1971, 1994; Goodman, 1971, 1982).

En contraposición al WL, desde el marco de la teoría cognitivista, surge la teoría de la Conciencia Fonológica. Para esta perspectiva, el éxito en el aprendizaje de la lectura y escritura se logra cuando se adquiere la capacidad de aislar fonemas y sus representantes discuten la desatención que existe en la enseñanza de las habilidades metafonológicas. Consecuentemente, se proponen diversidad de ejercicios de entrenamiento para posibilitar esos aprendizajes, tales como: reconocimiento de rimas, ritmo, versos sin sentido, identificación de los fonemas iniciales de las palabras, segmentación de palabras en sus fonemas, sintetizar o combinar fonemas para formar palabras, etc. (Defior, 1996). 
Algunos representantes de esta postura son Defior que realiza sus estudios en español (1994) y Morais en portugués (1998). En la Argentina, Ana María Borzone y su equipo apoyan el método fónico y han elaborado una serie de materiales educativos especialmente elaborados para trabajar con niños "que viven en zonas humildes" (Borzone y Rosemberg, 2007). Castedo y Torres, en su artículo "Un panorama de las teorías de la alfabetización en América Latina durante las últimas décadas" (1980-2010), comentan esta postura pedagógica:

\begin{abstract}
"El modo de facilitación supone dos operaciones: por una lado, la proximidad del contenido referido (la vida cotidiana del niño), por otro, la 'transcripción' del habla en la escritura, una operación compleja cuando pretende ir más allá del léxico para dar cuenta de la pronunciación, salvo que, como en este caso, se parta de la idea de que la lengua escrita refleja la oralidad. Por otra parte, desde el punto de vista pedagógico estamos ante una postura que plantea la necesidad de dar formato escolar, en libros de texto, a las formas culturales de fuera de la escuela, una idea contraria a llevar a la escuela la cultura oral y escrita de las comunidades para poder tomarlas como objeto de reflexión." (Castedo y Torres;
\end{abstract} 2012: 638.)

A partir de la década del 80 , diversas investigaciones y experiencias llevadas a cabo desde la perspectiva constructivista en el campo de la didáctica de la lectura y la escritura, realizadas en México, Venezuela, España, Brasil y Argentina, reconceptualizaron el objeto de enseñanza, así como el rol del alumno y el del maestro. (Lerner, Caneschi y otros 1985 y 1981; Lerner, 1987, 2001; Kaufman, 1988; 2007; Kaufman y Gomez Palacios, 1982; Kaufman, Castedo, Teruggi y Molinari, 1989; Teberosky, 1982, 1987, 1992; Tolchinsky, 1993; Weisz, 1996; Nemirosky, 1999) Estas nuevas propuestas, conocidas como "propuestas de enseñanza constructivistas" porque toman en consideración los resultados de las investigaciones psicogenéticas, nutrieron sus investigaciones didácticas en fuentes provenientes de otras disciplinas. Entre ellas podemos mencionar las contribuciones de historiadores (Chartier R., 1996; Chartier A. M. y Hebrard, 1994); lingüistas (Catach, 1996; Sampson, 1997; Bautier y Bucheton; 1997; Blanche Benveniste, 1998; Bronkart; 1999); antropólogos (Cardona, 1994) y sociólogos (Lahire,2004), también estudios psicolingüísticos (Flower y Hayes,1980; Goodman, 1982; Scardamalia y Bereiter, 1992; Olson, 1997) y psicogenéticos (Ferreiro y Teberosky, 1979; Teberosky y Tolchinsky, 1995).

El propósito principal de esta perspectiva es formar a los alumnos como practicantes de la cultura escrita. En ese sentido, es un cambio de prescripciones para el aula que requiere organizar las clases de una manera distinta a aquella que la escuela ha construido históricamente. Se redefine el objeto de enseñanza ${ }^{1}$ y los propósitos formativos, las prácticas sociales del lenguaje

\footnotetext{
${ }^{1}$ Se han diseñado en esta perspectiva diversos diseños curriculares que fundamentan el cambio de objeto y prescriben las Prácticas del Lenguaje para el trabajo en la escuela. Diseños curriculares de México en Educación Preescolar (1992 y 2004), Educación Básica y Primaria Indígena (ambos, 2006) y Primaria (2009). Parâmetros Curriculares Nacionais en
} 
complejizan y amplían el concepto de "la lengua" contenida en tales prácticas. Con este cambio de foco se "apunta a las dimensiones particulares del funcionamiento del lenguaje en relación con las prácticas sociales en general, dado que el lenguaje tiene una función de mediación respecto de estas últimas" (Lerner; 2001). No se trata solo de usar el lenguaje para comunicarse ni solo de ejercer prácticas por inmersión, sino de hacerlo logrando una progresiva descontextualización del lenguaje que se pone en juego, en situaciones que siempre cumplen con este propósito didáctico (en mayor o menor grado) y que, al principio -no necesariamente siempre- también tienen un propósito comunicativo que les da sentido inmediato (Castedo y Torres; 2012).

Las prácticas del lenguaje son prácticas culturales que incluyen no solo las conductas lingüísticas sino también los rituales, los usos y las costumbres asociados a ellas. Son también prácticas sociales en el sentido de que el valor de la utilización del lenguaje no es el mismo en diferentes grupos sociales y de que ese valor es reivindicado por diferentes grupos como factor de identidad. Poner énfasis en las prácticas del lenguaje supone considerar la actividad verbal como actividad simultáneamente cognitiva, social, subjetiva y -por supuesto- también lingüística, dado que implica la movilización y la elaboración de formas lexicales, sintácticas, textuales (Bautier; 1997).

Esta perspectiva intenta superar la tradicional separación entre "alfabetización en sentido estricto" y "alfabetización en sentido amplio". Esta separación es uno de los factores responsables de que la enseñanza en los primeros grados se centre en la sonorización desvinculada del significado y de que en grados posteriores se exija la comprensión del texto sin haber preparado a los alumnos para tal fin. Esta separación llevó a suponer que el manejo del sistema alfabético es un requisito previo a la utilización del lenguaje escrito (Lerner; 2001). Numerosas investigaciones sobre el acto lector (ya mencionadas en los puntos 1.2. y 1.3.), han puesto de manifiesto que la lectura consiste en la construcción del sentido del texto.

En el próximo ítem, se caracterizan de manera más detallada las propuestas constructivistas.

\subsection{Prácticas de enseñanza de la lectura orientadas por un marco constructivista}

Las investigaciones didácticas mencionadas en el punto anterior, diseñaron, desarrollaron y estudiaron situaciones didácticas e intervenciones docentes en diversidad de contextos institucionales que atienden a niños de distintos sectores socioeconómicos y culturales.

Uno de los problemas didácticos fundamentales fue tomar como objeto de referencia las prácticas sociales de la lectura y la escritura en el momento inicial de la alfabetización, cuando los niños 
están aún aprendiendo a leer y escribir. Como lo señalan Kaufman $(1998,2007)$ y Lerner $(1996$, 2010), entre otros, un principio didáctico orienta la respuesta a este problema: desde el primer día de clases, los niños comienzan a formarse como lectores y escritores, es decir, no hay una primera etapa donde se aprende a leer y a escribir y luego otra donde se lee y escribe "realmente".

Los alumnos pueden participar de verdaderos actos de lectura y escritura desde muy pequeños a través de cuatro situaciones fundamentales que coexisten en las aulas: la lectura a través del docente, la lectura de los niños por sí mismos, la escritura a través del docente y la escritura de los niños por sí mismos. En este apartado pormenorizaremos las dos situaciones de lectura en virtud del tema central de esta tesis.

La lectura a través del maestro se realiza de manera sistemática con textos de circulación social completos y variados, pertenecientes a diversos géneros. La conformación de una biblioteca de aula es imprescindible para cumplir con el propósito de formar a los alumnos como lectores. Esa biblioteca de aula se nutre e interactúa con la biblioteca institucional o barrial. Los libros que la conforman, en lo posible, son títulos que resultarán imprescindibles para los niños, aquellos que les permitirán encuentros con otros lectores de esas historias, los que se necesiten para llevar adelante las situaciones de enseñanza y aprendizaje. Los libros están a la vista y a disposición de los lectores.

Durante las situaciones en las que los niños leen a través del docente, acceden directamente a las características del lenguaje escrito (Teberosky, 1990) y participan activamente en la construcción del significado del texto que escuchan (Kaufman, 2007). De ese modo, elaboran anticipaciones y verificaciones que se pondrán poner en juego a la hora de intentar leer y escribir por sí mismos.

Los docentes planifican las lecturas, leen de manera sistemática y sostenida a lo largo del año (y del ciclo) diversos textos y propician situaciones de intercambio entre lectores para construir colectivamente los significados que el texto leído suscita. El docente lee y relee los textos, los deja a disposición para que los niños vuelvan a ellos, para reencontrar por sí mismos algunos pasajes de lo que el maestro leyó para todos. Los títulos de las obras, datos de los autores e ilustradores leídas se anotan a la vista de los niños (en afiches por ejemplo) para tenerlos presente.

En las situaciones de lectura por sí mismos los niños se enfrentan directamente con textos diversos, siempre de circulación social y no elaborados ad hoc, cualquiera sea su complejidad, a condición de que resulten previsibles a partir del contexto material y/o del contexto verbal que repone el docente. 
Claudia Molinari (2003: 64), en el artículo "La intervención docente en la alfabetización inicial", plantea que "las situaciones didácticas donde los pequeños lectores deben interpretar un texto por sí mismo se caracterizan por presentar la escritura de manera contextuada, es decir, siempre acompañada de un contexto material y/o contexto verbal". En cuanto al contexto material, Molinari aclara que muchos textos de circulación social suelen incluir dibujos o fotos. En estos casos, los niños anticipan el contenido del texto en virtud de las imágenes, y también a partir de las características materiales del portador, que brindan pistas acerca de su contenido (diario, libros, envases, folletos, etcétera). El contexto verbal es proporcionado por el docente para trabajar con textos que no están acompañados por imágenes. En relación a lo expuesto por Molinari, Ana María Kaufman (2007:31), sostiene que "en estos casos, el maestro brinda información global acerca de lo que está escrito. El trabajo intelectual que los niños ponen en acto cuando "leen" de estas dos maneras puede consistir en anticipar lo que creen que dicen o en ubicar dónde dice lo que él sabe que dice (a partir de la información previa suministrada por el docente)."

El conocimiento que se va construyendo no es sólo producto de estar en contacto con la cultura escrita sino también de la intervención deliberada del adulto, que les permite y les propone coordinar cada vez más información hasta poder leer por sí mismos. Entre la situación de escuchar leer al maestro y la de leer por sí mismo, es posible desarrollar una serie de variaciones.

Las propuestas de enseñanza no están concebidas como actividades aisladas sino que instalan una relación del tiempo y el saber que tiene en cuenta el tiempo del aprendizaje y preserva el sentido del objeto a enseñar: el sentido social de la lectura y de la escritura. Para ello se planificaron diferentes modalidades de organización de las actividades: las actividades habituales, los proyectos, las secuencias. Todas requieren que se dedique durante un cierto tiempo -ni efímero ni indefinido- al tratamiento de un eje temático como podría ser literario o de estudio. Como ya se ha desarrollado anteriormente, los niños logran desempeñarse como "buenos lectores" cuando han tenido oportunidad de frecuentar el tema o el género del texto que enfrentan o cuando, particularmente, conocen el texto.

Las actividades habituales permiten sostener, regularmente, el acercamiento a prácticas cuya principal característica es, precisamente, la regularidad: el uso más o menos independiente de la biblioteca escolar, institucional o barrial, la lectura del periódico, el seguimiento de una novela por capítulos así como el diario personal o la agenda donde se registran las actividades de la semana, son actividades que -en la vida cotidiana- se realizan de manera sostenida, lo que permite transformarlas en hábitos más o menos duraderos. En la escuela, se las propone sostenidamente a lo largo de ciertos períodos -un semestre, un mes, una quincena- y se les dedica un tiempo semanal breve previamente estipulado, de manera simultánea con el desarrollo de una secuencia o de un proyecto. 
Las secuencias proponen situaciones sucesivas y alternadas de lectura, escritura, intercambios orales y otras (búsqueda en Internet, entrevistas a especialistas, proyección de películas) organizadas alrededor de una práctica sostenida o un eje temático. Por ejemplo a la lectura de obras de un autor o de un género o subgénero, da lugar a que los niños adquieran sobre ellos diversos conocimientos: descubren las características de los personajes, el tipo de conflictos que más comúnmente enfrentan o provocan (las princesas de los cuentos, las brujas o los fantasmas, por ejemplo); advierten cuáles son los temas o los ambientes preferidos de un autor del que han escuchado leer o leído varias obras e incluso pueden relacionarlos con algunos datos de su biografía; reconocen características de un género - rápidamente los niños diferencian la ficción de la no ficción, el género narrativo del poético o el dramático, solamente por participar en sesiones habituales de lectura de unos y otros textos-.

Los proyectos persiguen propósitos didácticos pero plantean, a la vez, propósitos comunicativos explícitos y compartidos por los alumnos. Las sucesivas situaciones de lectura y de escritura y otras culminan en la exposición, la representación, la publicación, etc., es decir, con la concreción de esos propósitos.

Los conocimientos que los niños van adquiriendo en las situaciones sucesivas que proponen las modalidades organizativas los ayudan a anticipar cómo puede comenzar un cuento, qué puede ocurrir en cierta historia, cómo puede responder un personaje, qué información puede ofrecer un artículo con determinado título, etc. Los "nuevos" lectores, al igual que los lectores "expertos", tienen más posibilidades de leer con éxito un texto cuando se acercan a él disponiendo de conocimientos de los más variados tipos que solamente se adquieren cuando se tiene la oportunidad de visitar y revisitar temas, obras, géneros, autores. A la vez, en el marco de una secuencia o un proyecto, los niños enfrentan la producción de escrituras disponiendo de conocimientos sobre qué escribir y tienen también disponibles las fuentes a las que recurrir (libros, carteles, repertorios, escrituras preparatorias o intermedias) para saber cómo escribir. Los conocimientos previos, aquellos que son necesarios para leer o escribir con posibilidades de éxito, como se ve, se adquieren de manera progresiva, también en la escuela.

El docente planifica las diferentes modalidades de organización de las actividades y luego interviene activamente, interactuando con los niños y mediando entre ellos y el objeto de conocimiento para optimizar el proceso constructivo de apropiación de la lectura y la escritura. Durante el desarrollo de la situación didáctica el docente interviene para permitir o facilitar la construcción de conocimiento por parte de los niños. Estas intervenciones se conciben en relación con las estrategias que los niños desarrollan ante la situación planteada, poniendo en juego sus 
conceptualizaciones y se proponen crear las mejores condiciones para que los alumnos avancen desde un estado de "menor conocimiento hacia un estado de mayor conocimiento".

Fundamentalmente la intervención depende de lo que el docente interpreta en los niños, tanto en aquello que verbalizan como en la regularidad de sus acciones. No hay intervención didáctica adecuada sin conocimiento sobre los procesos de comprensión de los sujetos ni sobre los objetos que son asimilados.

La planificación de las diferentes modalidades considera de manera especial la interacción entre los alumnos con el docente y con el objeto de conocimiento son necesarias para que todos avancen en sus conocimientos. En función del problema que se les plantee se propone agrupar a los niños en pequeños grupos, en parejas, de manera individual o colectivamente.

Estas propuestas constructivistas responden a cinco criterios fundamentales: diversidad, continuidad, progresión, alternancia y simultaneidad que permiten la organización del año, del ciclo escolar y del grado en particular de tal modo que los alumnos puedan participar en la mayor diversidad posible de situaciones, mantener su continuidad, planificar situaciones simultáneas que se desarrollan en un mismo período del año, prever la progresión en que serán presentadas y sostenerlas con frecuencia cotidiana. (Lerner, 1980, 2001; Kaufman, 1988, 2007; Kaufman, Castedo, Teruggi y Molinari, 1989; Teberosky, 1992; Tolchinsky, 1993; Nemirovsky, 1999, 2009; Lerner y otros, 1987, 1996, 1998; Castedo y otros, 2001; Castedo, Molinari y otros, 2008; Castedo y otros, 2009 a, 2009b; Cutter y Kuperman, 2011).

La caracterización de algunos de los enfoques sobre la enseñanza de la lectura desarrollados en este ítem y el anterior constituyeron una referencia relevante para poder analizar las prácticas de enseñanza que en el presente trabajo denominamos $X$ y $Z$.

\subsection{Antecedentes relacionados con la búsqueda de información en libros}

Diversas investigaciones específicas aportan datos relevantes para orientar la temática que se aborda en este trabajo, resultados que dan cuenta de los conocimientos que los niños ponen en juego al interactuar con libros.

Marie Clay (1966) introdujo el término de "alfabetización emergente" (emergent literacy) para describir el comportamiento observado en niños pequeños -que no leían y escribían en el sentido convencional- cuando usaban libros y material escrito imitando las actividades de lectura y escritura. Basándose en las ideas de Clay, investigaciones posteriores sostienen que la alfabetización de los niños comienza mucho antes de la instrucción formal en la escuela primaria 
(Teale y Sulzby, 1986) y que este desarrollo de la alfabetización se nutre de las interacciones sociales con los adultos y la exposición a los materiales. Las investigaciones desde esta perspectiva demuestran que, si los niños han tenido contacto con materiales escritos en sus hogares, a partir de los tres años se interesan por la lectura y la escritura y van realizando un aprendizaje espontáneo de la misma. Por lo tanto, proponen el trabajo con las familias para estimular la lectura de los padres hacia los hijos y también crear un ámbito rico en alfabetización en el aula del Jardín de Infantes. Esta propuesta incluye tareas de lectura por parte del docente y los niños y también de escritura en contexto reales con situaciones de dictado al docente y escritura por parte de los niños.

En un estudio llevado a cabo entre 1977 y 1978 -con niños de entre 4 y 7 años de Monterrey, México - Ferreiro y Gómez Palacio han estudiado, entre otras cosas, las distinciones posibles que realizan los niños frente a un libro de cuentos. Se han tomado dos contextos escolares diferenciados: por un lado, la escuela urbana que recibe especialmente hijos de profesionales, con trabajo estable e ingresos de clases medias y, por otro lado, una escuela suburbana inserta en una población marginada, cuyos alumnos no han asistido al Jardín de Infantes. Una de las preguntas que formularon a los sujetos fue “¿Qué piensas que puede leerse allí?" (Ferreiro y Gómez Palacio, 1979: 34) apoyándose en investigaciones que muestran que la anticipación es un componente esencial en todo acto de lectura. Para responder a la pregunta los niños podían hacer uso de información no visual (el conocimiento de libros de cuentos) y de información visual como las ilustraciones. Las respuestas obtenidas fueron clasificadas en cuatro grupos: a) realizan una predicción tomando en cuenta el contenido de las imágenes, ajustándose a ciertas características del género literario en cuestión; b) realizan una predicción en base al contenido de la imagen, sin tomar en consideración las características narrativas de los cuentos; c) respuestas que parecen ignorar lo que es un libro de cuentos y no utilizan la imagen para anticipar el contenido del texto no las usan porque no consideran aún a las letras como objetos simbólicos que remiten a un significado o bien porque las letras sirven para escribir "nombres" - y d) respuestas que indican que las letras no son concebidas como objetos simbólicos, pero se distinguen del grupo anterior en que tratan al texto de una manera muy similar al dibujo, particularmente cuando el texto está vinculado con una imagen. Otro aspecto que analizaron las autoras fue la orientación de la lectura por considerarla un indicador de la participación de los niños en múltiples actos de lectura.

En las investigaciones de lectura de Emilia Ferreiro $(1979 ; 1986)$ en las tareas de lectura diseñadas el contexto ocupa un papel relevante. Ese contexto puede ser material -dado por una imagen o un portador como ya se ha señalado- o verbal, en el que el investigador brinda al niño cierta información sobre lo escrito pero no dónde dice. Es a partir de esa información verbal que se plantean problemas de relación entre el todo y las partes. Los niños aprenden a leer intentando 
coordinaciones cada vez más ajustadas entre el texto y el contexto, a través de una actividad conceptual importante.

Otra de las tareas diseñadas por esta investigadora arrojó datos sobre el significado que asignan los niños a la segmentación de una oración escrita, a partir de los cuales se logró analizar las conceptualizaciones infantiles en torno a las partes gramaticales que consideran pueden estar escritas. Para ello, se presentaba una oración escrita, se la leía mientras se señalaba de manera continua el texto y se solicitaba al niño la interpretación de cada uno de sus segmentos (alternando las preguntas "dónde dirá...", "qué dirá aquí").

En estos estudios se han podido identificar varios tipos de respuestas que permiten trazar una línea evolutiva de acuerdo al tipo de interpretación que los niños adjudican a los diferentes segmentos. En un principio, los niños suponen que sólo los sustantivos están escritos. Evolutivamente superiores son las respuestas que aíslan también el verbo. Comprender que los artículos y las preposiciones están escritos en el texto requiere de un avance en los niveles de conceptualización ya que estas palabras no tienen significado propio ni condiciones cuantitativas (en este caso no tienen el mínimo de letras establecido por la generalidad de los niños para ser legibles) (Ferreiro y Teberosky, 1979). Según los resultados de esta investigación, los niños establecen una distinción original, ya que mantienen una diferenciación entre lo que puede leerse (pues aceptan y repiten lo que lee el experimentador en la oración completa) y lo que efectivamente piensan que está escrito (Ferreiro y Teberosky, 1979; Ferreiro, E. y Gómez Palacio, 1979).

No hemos encontrado investigaciones que analicen los conocimientos que ponen en juego niños de 5 y 6 años cuando tienen delante un texto enciclopédico para localizar información después de permanecer durante un año escolar en el ambiente privilegiado que brinda la situación de clase a través del contacto sistemático con la cultura escrita.

Entre las escasas experiencias de aula que dan cuenta de lo que ocurre cuando se pone a disposición de los niños pequeños este tipo de materiales, cabe mencionar el trabajo del equipo de Prácticas de Lenguaje de la Provincia de Buenos Aires (Castedo, M. y otros 2009) se trata de una serie de documentos que enmarcados en contexto de estudio abordan la temática sobre la diversidad en los animales en $1^{\circ}$ y $2^{\circ}$ grado; un trabajo de en el que los niños hacen aproximaciones al explorar enciclopedias para resolver problemas de lectura y escritura (Molinari, 2000) y otro en el que los alumnos buscan datos biográficos o datos de pintores en textos informativos (Nemirovsky, 1999). 


\section{CAPÍTULO II \\ OBJETIVOS Y PREGUNTAS DE INVESTIGACIÓN, HIPÓTESIS Y DISEÑO METODOLÓGICO}

\subsection{Objetivos y preguntas de investigación}

Objetivos:

a) Contrastar las respuestas de niños que se encuentran culminando el Nivel Inicial y Primer Grado de la escuela primaria y que asisten a instituciones con prácticas de enseñanza diferentes.

b) Analizar determinados conocimientos infantiles sobre diferentes libros - un cuento y una enciclopedia - en los que aparece el mismo tipo de insecto (abeja).

c) Indagar las estrategias utilizadas para localizar información específica en una enciclopedia.

Interrogantes que orientaron la investigación:

1. ¿Qué libro escogen los alumnos para "saber más" sobre las abejas y cuáles son los argumentos que esgrimen para justificar su elección? ¿Hay diferencias en las respuestas de los niños en función del nivel de escolaridad y contexto de enseñanza? En caso afirmativo, ¿cuáles son?

2. ¿Qué página de la enciclopedia seleccionan inicialmente, qué aspectos toman en consideración para localizar una información específica y cuál es la estabilidad de la elección inicial frente a las intervenciones del investigador? ¿Hay diferencias en las respuestas de los niños en función del nivel de escolaridad y contexto de enseñanza? En caso afirmativo, ¿cuáles son? 


\subsection{Hipótesis de la investigación}

En la presente investigación hemos indagado el contraste entre cuatro grupos de niños - dos de Jardín y dos de Primer Grado - que participaron de propuestas de enseñanza diferentes Escuelas $X$ y Escuelas $Z$ que caracterizaremos más adelante.

Mantuvimos fijas dos variables: el nivel socioeconómico de las familias y los docentes. En relación con la primera variable, seleccionamos niños cuyo ámbito familiar se caracteriza por tener escasas oportunidades de acceso a la lengua escrita. En relación con la segunda variable, escogimos docentes particularmente involucrados con el aprendizaje de sus alumnos ya que esto garantizaba que los niños hubieran tenido un entorno educativo estimulante y comprometido.

Las hipótesis centrales de este trabajo son:

Hipótesis 1 - Si bien es probable que la mayoría de los niños (de ambos contextos de enseñanza) pueda identificar adecuadamente la enciclopedia como el libro que contiene información sobre las abejas, es esperable que quienes han participado de prácticas de enseñanza que sostienen situaciones sistemáticas en torno a los libros justifiquen su elección a partir de indicadores vinculados con aspectos del sistema de escritura, del lenguaje escrito y/o de los libros como objetos culturales.

Hipótesis 2 - Frente a la tarea de localizar una página de la enciclopedia para encontrar información específica sobre las abejas, es posible que haya diferencias en las estrategias utilizadas los niños de Escuelas X y los de las Escuelas Z. 


\subsection{Diseño metodológico}

Para los propósitos de esta investigación, tiene igual relevancia el análisis cuantitativo y cualitativo de los datos. Se han construido categorías de análisis a partir de las respuestas infantiles así como de los procedimientos utilizados en el proceso de resolución de los problemas planteados.

\subsubsection{Población}

La población seleccionada está constituida por 122 niños de Jardín de Infantes y Primer Grado.

Se seleccionaron niños de cuatro Salas de cinco años y de cuatro Primeros Grados. Todos los niños pertenecen a escuelas públicas donde asisten poblaciones de bajos recursos socioeconómicos.

Los padres han asistido a la escuela primaria y en su mayoría han completado solamente ese nivel de escolaridad como único de la educación formal.

Para la selección de los grupos escolares se utilizaron distintos procedimientos: entrevistas a supervisores, equipos directivos y docentes; análisis de documentos diversos (cuadernos de clase, planificaciones y materiales de lectura a disposición en el aula); observaciones y registros de un conjunto de situaciones didácticas desarrolladas que permitieron una descripción más detallada de algunas prácticas de enseñanza en torno a la lectura y la escritura.

Los cuatro grupos se componen de la siguiente manera:

El primer grupo está conformado por 30 niños de sala de 5 años, seleccionados en dos Jardines de Infantes (15 niños de cada Jardín) que participaban en prácticas de enseñanza que podríamos identificar como "usuales" o "tradicionales" basadas en el desarrollo de un conjunto de habilidades perceptivo motrices y enseñanza graduada de letras. Lo identificamos como grupo X y se denominarán, de aquí en adelante, Jardines X (JX).

El segundo grupo de 34 niños $^{1}$ de sala de 5 años seleccionados en otros dos Jardines de Infantes (17 niños de cada uno) participaban en prácticas caracterizadas como "constructivistas". Lo identificamos como grupo $Z$ y se denominarán, de aquí en adelante, Jardines Z (JZ).

\footnotetext{
${ }^{1}$ En los jardines se incluyeron más niños en el estudio ante posibles deserciones a lo largo de las tomas. En el caso de las Escuelas $Z$ no las hubo y resultó difícil encontrar un criterio de selección, por lo tanto, decidimos incluirlos a todos ya que los porcentajes ayudarían a borrar las diferencias en la composición del número de niños de cada grupo de escuelas.
} 
El tercer grupo de $26^{2}$ niños de Primer Grado seleccionados en dos escuelas primarias (15 de una y 11 de la otra) participaba en prácticas de enseñanza que podríamos identificar como "usuales" o "tradicionales", al igual que los JX. Lo identificamos como grupo X y serán denominados Primeros X (PX).

El cuarto y último grupo, de 32 niños de Primer Grado seleccionados en dos escuelas primarias (16 niños de cada una), participaban en prácticas caracterizadas como "constructivistas". Lo identificamos como grupo $Z$ y en adelante serán denominados Primeros Z (PZ).

Para la selección de la población se tuvo en cuenta que los niños:

1) Contaran con un $70 \%$ de asistencia para garantizar que hubieran participado con continuidad en las propuestas de enseñanza. Los niños debían haber asistido de manera regular durante el año escolar. La decisión de no tomar el grupo escolar completo permitió cumplir con estas condiciones.

2) No presentasen -según criterio de los docentes- dificultades familiares o psicopedagógicas severas a fin de hacer posibles las comparaciones, ya que el impacto de estas variables en el desempeño de los niños es muy difícil de controlar.

3) Representaran la heterogeneidad siempre presente en un aula en cuanto a los niveles de desempeño en clase, de acuerdo al criterio de sus maestras. En consecuencia, a cada una se le solicitó que seleccionara:

- Cinco niños "considerados de los mejores en Lengua, que necesitan poca ayuda para resolver las tareas" (sub-grupo $\mathrm{A})^{3}$.

- Cinco niños "que presentan mayor dificultad en realizar tareas en Lengua, que necesitan más ayuda para cumplir con los aprendizajes esperados" (subgrupo C).

- Cinco niños "considerados en un nivel intermedio en relación a la manera en que resuelven las tareas en Lengua y a la ayuda que necesitan para abordarlas" (subgrupo B).

\footnotetext{
${ }^{2}$ En el momento de levantar los datos en esta escuela situaciones diversas provocaron un importante ausentismo en las aulas (paros docente y condiciones meteorológicas).

${ }^{3}$ Para la solicitud a los maestros se utiliza la palabra "Lengua" en tanto denominación escolar más usual que hace referencia a situaciones didácticas de lectura, escritura y oralidad. La solicitud incluye además dos aspectos frecuentemente utilizados por los docentes para caracterizar a sus alumnos: niveles de desempeño y ayuda que requieren para la realización de las propuestas escolares. Fue una decisión de la investigación formular la solicitud en tales términos a fin de que resultase lo más clara posible para quienes debían decidir la selección de los alumnos según subgrupos A-B-C.
} 
4) Pertenecieran a familias de condición económica desfavorecida. Para ello se tuvo en cuenta la información relativa al nivel de instrucción familiar.

5) Se distribuyeran equilibradamente en relación con el género.

La tabla 1 muestra cómo quedaron conformados los grupos:

Tabla 1: Cantidad de niños estudiados en Jardín: Escuelas X/Z de acuerdo a mujeres/varones.

\begin{tabular}{|c|c|c|c|c|}
\hline \multirow{2}{*}{$\begin{array}{c}\text { Niños estudiados } \\
\text { Jardín }\end{array}$} & \multicolumn{2}{|c|}{ Escuelas X } & \multicolumn{2}{c|}{ Escuelas Z } \\
\cline { 2 - 5 } & $\mathbf{M}$ & $\mathbf{V}$ & $\mathbf{M}$ & $\mathbf{V}$ \\
\cline { 2 - 5 } Subtotal Jardín & \multicolumn{2}{|c|}{30} & \multicolumn{2}{|c|}{34} \\
\hline Total & \multicolumn{3}{|c}{$\mathbf{6 4}$} \\
\hline
\end{tabular}

Tabla 2: Cantidad de niños estudiados en Primer Grado: Escuelas X/Z de acuerdo a mujeres/varones.

\begin{tabular}{|c|c|c|c|c|}
\hline \multirow{2}{*}{$\begin{array}{c}\text { Niños estudiados } \\
\text { Primer Grado }\end{array}$} & \multicolumn{2}{|c|}{ Escuelas X } & \multicolumn{2}{c|}{ Escuelas Z } \\
\cline { 2 - 5 } & $\mathbf{M}$ & $\mathbf{V}$ & $\mathbf{M}$ & $\mathbf{V}$ \\
\cline { 2 - 5 } $\begin{array}{c}\text { Subtotal } \\
\text { Primer Grado }\end{array}$ & \multicolumn{2}{|c|}{$26^{4}$} & \multicolumn{2}{|c}{32} \\
\hline Total & \multicolumn{3}{|c|}{$\mathbf{5 8}$} \\
\hline
\end{tabular}

En síntesis, el grupo estudiado quedó conformado por 122 niños: 64 provenientes de Jardines de Infantes y 58 niños provenientes de Primeros Grados. Se constituyeron, entonces, cuatro grupos, dos de cada nivel de escolaridad (Inicial y Primario) y, en cada nivel, uno de los grupos se caracterizaba por prácticas de enseñanza usual (JX y PX) y el otro, por prácticas constructivistas (JZ y PZ). En el próximo apartado describimos cada contexto de enseñanza.

\subsubsection{Caracterización de las propuestas didácticas de las Escuelas $X$ y $Z$}

Fueron seleccionadas cuatro maestras que se desempeñaban en las cuatro instituciones de Educación Inicial y cuatro en Primer Grado de la enseñanza básica con las que trabajamos: dos representantes de las propuestas del Grupo X y dos del Grupo Z en cada nivel de escolaridad. Ellas fueron las que tuvieron a su cargo la selección de los niños en cada uno de sus grupos.

\footnotetext{
${ }^{4}$ Tomamos esa cantidad de referencia ya que, como veremos más adelante las tareas analizadas en la presente tesis se tomaron en la segunda entrevista y esos días asistieron por menos alumnos en PX.
} 
Por tratarse de un estudio que analiza el desempeño de niños que participaron de dos propuestas didácticas diferentes, era necesario situar la variable "docente" en igualdad de condiciones. Por lo tanto, la búsqueda de las mejores condiciones posibles para cada una de las aproximaciones metodológicas fue una cuestión especialmente atendida. Las docentes debían ser buenas referentes de las dos propuestas didácticas contrastantes. Eran, en su totalidad, maestras comprometidas con la enseñanza, con asistencia continua durante el período escolar, antigüedad en el ciclo, bien conceptuadas dentro de su escuela por su desempeño, comprometidas con la población con la que trabajaban y llevaran a cabo un trabajo planificado y sostenido.

Para la selección, se utilizaron distintos procedimientos: entrevistas a directivos y a las mismas docentes, observaciones de situaciones de enseñanza que permitieran una descripción más detallada acerca de lo que ocurre en el salón de clase y análisis de documentos (cuadernos de clase o carpetas, planificaciones, materiales de lectura dispuestos en el aula, otros materiales didácticos utilizados en tareas de lectura y escritura).

Diversos fueron los materiales recogidos que nos permitieron analizar las prácticas de enseñanza en los grupos estudiados:

- Entrevistas a miembros del equipo directivo de la institución y a los docentes a cargo de los grupos estudiados.

- Documentos escolares: planificaciones de los docentes, carpetas y cuadernos de los alumnos, proyectos institucionales.

- Materiales escritos en el ámbito del aula.

- Registros de clases en cada uno de los grupos.

Como este estudio pone en relevancia prácticas de enseñanza contrastantes, en primer término caracterizaremos, brevemente, los rasgos esenciales de cada grupo de escuelas y luego expondremos, en cuadros comparativos y de manera más pormenorizada, algunas cuestiones vinculadas con: el uso de la biblioteca, las situaciones de lectura, los materiales escritos en el ámbito del aula, las situaciones de escritura, el uso del cuaderno, la intervención docente y la interacción entre los niños.

\subsubsection{Rasgos esenciales de las prácticas de enseñanza en los grupos $X$}

- Escasa circulación de materiales escritos en el aula y poca reflexión sobre los mismos.

- Situaciones de lectura orientadas al descifrado.

- Presencia en el aula solo de escrituras convencionales. 
- Situaciones de escritura y lectura de palabras y progresivamente oraciones, desvinculadas de los usos sociales.

- Poca presencia de la lectura por parte del maestro.

- Situaciones didácticas con fuerte presencia de la copia y la memorización.

- Aprendizaje de las letras por presentación graduada y ejercicios de refuerzo para su fijación.

- Escasa interacción entre pares en la resolución de tareas de lectura y escritura; docente instalado como único informante.

- Circulación de texto escolar único en primer grado.

- En sala de 5 años fuerte presencia de tareas de aprestamiento.

- Intervenciones del docente que apuntan a la corrección del error.

\subsubsection{Rasgos esenciales de las prácticas de enseñanza en los grupos $Z$}

- Circulación de diversos materiales escritos que responden a diversos propósitos y presentan variedad de géneros con los que se realizan prácticas sociales de lectura y escritura.

- Situaciones didácticas diversas y continuas de lectura y escritura en las que se abordan propuestas de escritura por sí mismos y a través del docente, lectura por sí mismos y a través del docente.

- Diferentes modalidades organizativas de las actividades de lectura y escritura: actividades habituales, proyectos de producción de textos con un producto final que tiene un destinatario real, secuencias de escritura, lectura y/o reflexión y actividades independientes.

- Presencia de escrituras no convencionales en el aula y en los cuadernos de clase.

- Espacios para la reflexión sobre las propias escrituras y las de otros.

- Valoración positiva del lugar del error y la revisión de las producciones propias y ajenas.

- Promoción del intercambio entre pares y con el docente.

- Intervenciones del docente en función de diferentes roles del maestro. 


\subsubsection{Cuadros comparativos}

En la mayor parte de los cuadros se consignan, al comienzo de las columnas, los aspectos generales. Luego se especifican las particularidades encontradas en Jardín (J) y en Primer Grado $(\mathrm{P})$

\begin{tabular}{|c|c|}
\hline \multicolumn{2}{|c|}{ USO DE LA BIBLIOTECA } \\
\hline ESCUELAS X & ESCUELAS Z \\
\hline $\begin{array}{l}\text { J: Sector destinado a biblioteca de sala. } \\
\text { Presencia exclusiva de libros literarios: } \\
\text { cuentos y poesías de pocos autores } \\
\text { consagrados. Se propone su uso cuando es } \\
\text { el momento del trabajo en rincones o cuando } \\
\text { queda tiempo libre. Si bien existe la } \\
\text { posibilidad de que los niños lleven libros a su } \\
\text { casa, no está instalado ese funcionamiento } \\
\text { de manera sistemática. No se constató } \\
\text { ninguna actividad que registrara esos } \\
\text { préstamos ni que retomara las elecciones y/o } \\
\text { las lecturas realizadas por los niños en sus } \\
\text { casas. }\end{array}$ & $\begin{array}{l}\text { - Biblioteca de la escuela con cantidad y } \\
\text { variedad de libros, con préstamos a los niños y a } \\
\text { las familias. } \\
\text { - Bibliotecas de aula tanto en J como en P. Las } \\
\text { bibliotecas contienen libros literarios y en menor } \\
\text { medida libros enciclopédicos o de información } \\
\text { diversa. Se realizan préstamos domiciliarios } \\
\text { sistemáticos y queda registrado quién se lo lleva } \\
\text { y cuándo lo devuelve. Hay situaciones que } \\
\text { retoman las lecturas que se han realizado. Se } \\
\text { renuevan los títulos a lo largo del año. } \\
\text { (Ver Anexo II Material 9) } \\
\text { J: Se confecciona el listado de títulos con los } \\
\text { alumnos. Realizan encuentros con algunos } \\
\text { escritores de quienes han leído varios títulos, por } \\
\text { ejemplo, Mónica Weiss. }\end{array}$ \\
\hline $\begin{array}{l}\text { P: Ausencia de biblioteca de aula. El niño que } \\
\text { desea puede llevarse libros de la biblioteca } \\
\text { institucional y el préstamo lo registra la } \\
\text { bibliotecaria. Las maestras desconocen } \\
\text { quiénes llevan libros y cuáles escogen. Sin } \\
\text { embargo alientan a los alumnos para que } \\
\text { vayan en los recreos. }\end{array}$ & $\begin{array}{l}\text { P: Se confecciona, desde el inicio del año, un } \\
\text { fichero con fichas donde los mismos niños son } \\
\text { los que registran los títulos de los libros que se } \\
\text { dan en préstamo. Tienen diversos catálogos } \\
\text { donde señalan los que necesitan para el } \\
\text { proyecto "Seguir la obra de Gustavo Roldán". } \\
\text { Los marcan para luego ir a la librería cercana a } \\
\text { comprarlos para su biblioteca. } \\
\text { En uno de los grados había profusión de } \\
\text { historietas de Mafalda, porque abordaron un } \\
\text { proyecto sobre esa tira. La maestra incluye en la } \\
\text { biblioteca del aula varios libros que ha leído en } \\
\text { voz alta con el fin de que los niños puedan } \\
\text { revisitarlos. } \\
\text { (Ver Anexo II Material 17) }\end{array}$ \\
\hline
\end{tabular}




\begin{tabular}{|c|c|}
\hline \multicolumn{2}{|c|}{ SITUACIONES DE LECTURA } \\
\hline ESCUELAS X & ESCUELAS Z \\
\hline $\begin{array}{l}\text {-Situaciones ocasionales, aisladas y azarosas } \\
\text { de lectura por parte de la maestra. } \\
\text {-Escasas situaciones de lectura por sí mismos } \\
\text { orientadas al descifrado. }\end{array}$ & $\begin{array}{l}\text {-Situaciones sistemáticas y sostenidas de lectura } \\
\text { a través de la maestra. Intercambio entre } \\
\text { lectores luego de esas lecturas. } \\
\text {-Situaciones de lectura de los niños por sí } \\
\text { mismos en el contexto de los proyectos y } \\
\text { secuencias trabajadas. }\end{array}$ \\
\hline $\begin{array}{l}\text { J: Cuando se propone una actividad después } \\
\text { del momento de lectura suele ser: "Dibujar lo } \\
\text { que más me gustó". }\end{array}$ & $\begin{array}{l}\text { J: Se realiza una agenda de lecturas en el marco } \\
\text { de los proyectos (por ejemplo "cuentos } \\
\text { tradicionales") y se van tildando los que se leen. } \\
\text {-Se planifican situaciones de lectura por sí } \\
\text { mismo: se entregan dos títulos de cuentos } \\
\text { conocidos y se solicita saber "cuál es cual" o } \\
\text { "dónde dice...". } \\
\text {-Lectura de los carteles de la sala. }\end{array}$ \\
\hline $\begin{array}{l}\text { P: Identificación de palabras al comienzo del } \\
\text { año que progresivamente se extiende a lectura } \\
\text { de frases. } \\
\text { Circulación de un texto escolar único. } \\
\text { En uno de los grados, la lectura de cuentos en } \\
\text { voz alta estaba a cargo del personal del } \\
\text { gabinete una vez por semana. La maestra dice: } \\
\text { "lo eligen ellas y no se vincula con el trabajo en } \\
\text { el aula." }\end{array}$ & $\begin{array}{l}\text { P: Lectura de recomendaciones, de historietas, } \\
\text { de cuentos, etc., que funcionan como modelo } \\
\text { para las escrituras de los proyectos. } \\
\text {-Situaciones de lectura enmarcadas en los } \\
\text { proyectos. En las aulas queda registro de ciertas } \\
\text { frases y palabras de uso frecuente. } \\
\text {-En un grado se leyó una novela clásica, "Las } \\
\text { aventuras de Pinocho", de Carlo Collodi por } \\
\text { capítulos desde mitad de año. Lectura de } \\
\text { historietas de Mafalda. } \\
\text {-En otro grado leyeron textos de Gustavo Roldán } \\
\text { e investigaron sobre su vida y su obra. } \\
\text {-Leen cuentos tradicionales. }\end{array}$ \\
\hline
\end{tabular}




\begin{tabular}{|c|c|}
\hline \multicolumn{2}{|c|}{ MATERIALES ESCRITOS EN EL ÁMBITO DEL AULA } \\
\hline ESCUELAS X & ESCUELAS Z \\
\hline $\begin{array}{l}\text { En las paredes de las aulas de Jardín y } \\
\text { Primer Grado se observan escasos materiales } \\
\text { escritos: } \\
\text { - Cartel de Bienvenidos, } \\
\text {-Abecedarios ilustrados preestablecidos con } \\
\text { el nombre del objeto escrito debajo. } \\
\text {-Nombres propios. } \\
\text {-Afiche con el nombre de la estación en curso } \\
\text { - otoño, invierno, primavera- y una ilustración. } \\
\text { J: Los carteles con los nombres propios de } \\
\text { cada niño permanecían guardados hasta que } \\
\text { consideraran que su uso fuera necesario en el } \\
\text { marco de alguna actividad específica. } \\
\text {-En uno de los Jardines hay un almanaque y } \\
\text { dibujos de los niños. Algunos tienen los } \\
\text { nombres de los niños. } \\
\text { P: "Todas llevan MP" y luego palabras } \\
\text { escritas por los niños con esas letras. }\end{array}$ & $\begin{array}{l}\text { Se observan materiales semejantes en las } \\
\text { paredes de Jardín y de Primer Grado: } \\
\text {-Portadores de uso social: almanaques, agendas. } \\
\text {-Afiches con palabras y frases que se vinculan } \\
\text { con los proyectos y secuencias de actividades } \\
\text { planificadas: se observan tanto escrituras } \\
\text { convencionales como no convencionales de los } \\
\text { niños. Algunas de estas escrituras presentan } \\
\text { trascripciones de aquello que los niños quisieron } \\
\text { escribir a fin de que pudieran ser comunicables } \\
\text { para otros. Se observan revisiones de sus } \\
\text { escrituras. } \\
\text {-Carteles con los nombres de los alumnos escritos } \\
\text { con letras mayúsculas ubicados en lugares donde } \\
\text { los niños pueden acceder con facilidad a ellos: } \\
\text { debajo del pizarrón, algunos debajo de la letra del } \\
\text { abecedario correspondiente, otros ubicados en un } \\
\text { panel que se extraen con velcro o alfileres. } \\
\text {-Carteles con los meses del año donde se } \\
\text { informan los cumpleaños y los días de la semana. } \\
\text {-Carteles con la lista de los cuentos leídos } \\
\text { durante el año, autores, editoriales, registro de } \\
\text { préstamo de libros. } \\
\text {-Recomendaciones de libros, informaciones } \\
\text { escritas por el docente a la vista de todos, en } \\
\text { papel afiche. }\end{array}$ \\
\hline
\end{tabular}




\begin{tabular}{|c|c|}
\hline \multicolumn{2}{|c|}{ SITUACIONES DE ESCRITURA } \\
\hline ESCUELAS X & ESCUELAS Z \\
\hline $\begin{array}{l}\text { J: Escritura del nombre propio en forma reiterada a lo } \\
\text { largo de toda una hoja. } \\
\text {-Escritura de palabras a cargo de la maestra siempre } \\
\text { en el pizarrón, luego los niños las copian; listados de } \\
\text { palabras recortadas de diarios o revistas y pegadas } \\
\text { en cuadernos y al lado, su copia. } \\
\text {-Escrituras con el propósito de desarrollar la } \\
\text { percepción, la motricidad fina y la organización } \\
\text { espacial: letras, sílabas, repetición de series de } \\
\text { patrones gráficos. } \\
\text {-Presentación de las vocales a través de propuestas } \\
\text { como: dibujar cosas que empiezan con "a"; pensar } \\
\text { palabras que empiecen con "a" (las pensaban } \\
\text { colectivamente y la maestra las escribía en el pizarrón } \\
\text { para que las copiaran). Estos tipos de actividades se } \\
\text { repiten con todas las vocales. } \\
\text { (Ver Anexo II Materiales } 1 \text { a } 7 \text { ) }\end{array}$ & $\begin{array}{l}\text {-Por lo general, la escritura forma parte de } \\
\text { actividades habituales, secuencias y proyectos. } \\
\text {-Las propuestas de escritura corresponden a las } \\
\text { dos situaciones didácticas fundamentales: } \\
\text { escritura por sí mismos y a través del maestro. En } \\
\text { este último caso, los textos suelen ser más } \\
\text { extensos que cuando lo hacen por sí mismos y } \\
\text { permiten realizar reflexiones y revisiones sobre el } \\
\text { lenguaje escrito. } \\
\text {-En las situaciones de escritura por sí mismos se } \\
\text { observan producciones que corresponden a } \\
\text { diferentes niveles de la construcción del sistema. } \\
\text { J: En las salas se observan testimonios de } \\
\text { revisiones individuales y también escrituras y } \\
\text { reescrituras en parejas. En las planificaciones de } \\
\text { los proyectos se observa una diversidad de este } \\
\text { tipo de situaciones que abarcan escritura de } \\
\text { palabras (utilizando lápiz o a través de letras } \\
\text { móviles) y otros textos más extensos. Lo que se } \\
\text { escribe siempre se plantea con claros propósitos. } \\
\text { Los niños saben escribir y por qué. } \\
\text { (Ver Anexo II Materiales } 8 \text { y 10) }\end{array}$ \\
\hline $\begin{array}{l}\text { P: Se proponen actividades similares a las de Jardín. } \\
\text { Enseñanza de las letras en cierto orden. Según } \\
\text { manifestó una de las maestras: "Primero las vocales, } \\
\text { luego la eme, la pe (por asociación a mamá y papá), } \\
\text { la ese por ser la de sol, palabra corta que la trabajan } \\
\text { mucho en jardín. Luego la te, la de, la jota... La } \\
\text { presentación de las letras es casi siempre igual: se } \\
\text { toma la escritura del nombre de alguno de los chicos } \\
\text { del grado que empiece o tenga la letra que voy a } \\
\text { enseñar esa semana o ese día y después asocian el } \\
\text { nombre con otras palabras. Les pido que dibujen las } \\
\text { letras con el dedo en el aire." } \\
\text { Se presentan simultáneamente los cuatro tipos de } \\
\text { letras (imprenta mayúscula y minúscula, cursiva } \\
\text { mayúscula y minúscula). } \\
\text { Permiten que los niños escriban en imprenta } \\
\text { mayúscula hasta el mes de octubre en que abordan la } \\
\text { letra cursiva. } \\
\text { A fin de año escriben "oraciones fáciles" por ejemplo: } \\
\text { la paloma es blanca' y completan sílabas de } \\
\text { palabras, por ejemplo, - rafa (para garrafa); co_jo } \\
\text { (para conejo). } \\
\text { En voz de una de las maestras "Repiten la 'eme' con } \\
\text { la 'a", así con todas, es rutinario pero se } \\
\text { acostumbran" } \\
\text { (Ver Anexo II Materiales } 11,12,13,14 \text { ) }\end{array}$ & $\begin{array}{l}\text { P: Escrituras de recomendaciones de la obra del } \\
\text { autor que están leyendo a partir de la lectura de } \\
\text { otros modelos de recomendaciones para que } \\
\text { integren un folleto. } \\
\text {-Leen datos de la vida y la obra del autor } \\
\text { abordado. } \\
\text {-Escriben, a través del maestro, cartas, recetas, } \\
\text { partes de una revista sobre los alimentos, en la } \\
\text { cual los padres, junto a sus hijos, inventan juegos } \\
\text { que se incorporarán a la misma. } \\
\text {-Escritura de posibles finales de capítulos antes } \\
\text { de leer los últimos párrafos. } \\
\text {-Escritura de recomendaciones de cuentos leídos. } \\
\text {-Los niños escriben en imprenta mayúsculas pero } \\
\text { en los carteles los tipos de letras son diversos. } \\
\text { (Ver Anexo Il Materiales } 15,16,18,19 \text { ) }\end{array}$ \\
\hline
\end{tabular}




\begin{tabular}{|c|c|}
\hline \multicolumn{2}{|c|}{ USO DEL CUADERNO } \\
\hline ESCUELAS X & ESCUELAS Z \\
\hline $\begin{array}{l}\text { J: Su uso comienza a partir de mitad de año, } \\
\text { vinculado al propósito de aprender a manejarse } \\
\text { en un espacio reducido. El cuaderno se organiza } \\
\text { con distintos tipos de hojas: lisas, particionadas } \\
\text { (con una división horizontal, vertical, en cruz), con } \\
\text { margen, con dos renglones grandes, con tres, } \\
\text { cuatro, hasta completar la hoja como en los } \\
\text { cuadernos de uso habitual. Eligen este tipo de } \\
\text { cuadernos porque según el criterio de sus } \\
\text { maestras "presentan un creciente nivel de } \\
\text { dificultad". } \\
\text {-Las actividades muestran fuerte presencia de } \\
\text { tareas de aprestamiento. Se consideran } \\
\text { preparatorias para Primer Grado. También se les } \\
\text { pide recortar palabras cortas y largas de diarios y } \\
\text { revistas. } \\
\text { Algunas consignas: "Dibujo cosas que empiecen } \\
\text { con A", "Uno con flechas" para hacer } \\
\text { corresponder el dibujo con su nombre escrito. En } \\
\text { la última página del cuaderno de uno de los } \\
\text { Jardines figura un índice escrito por la maestra } \\
\text { haciendo referencia a todas las actividades } \\
\text { realizadas. } \\
\text { (ver Anexo II materiales 1,a } 7 \text { ) } \\
\text { P: Ocupa un lugar importante en el quehacer } \\
\text { cotidiano desde principio del año escolar, su uso } \\
\text { comienza cuando se inician las clases. } \\
\text { Las escrituras que se observan son copias de lo } \\
\text { que escribe la maestra en el pizarrón } \\
\text { (mayoritariamente palabras en la primera mitad } \\
\text { del año). No aparece ninguna escritura que no } \\
\text { sea convencional. } \\
\text { En uno de los primeros grados, los niños tienen } \\
\text { un cuaderno de ortografía y una vez por semana } \\
\text { realizan actividades. } \\
\text { (ver Anexo II materiales } 11 \text { a 13) }\end{array}$ & 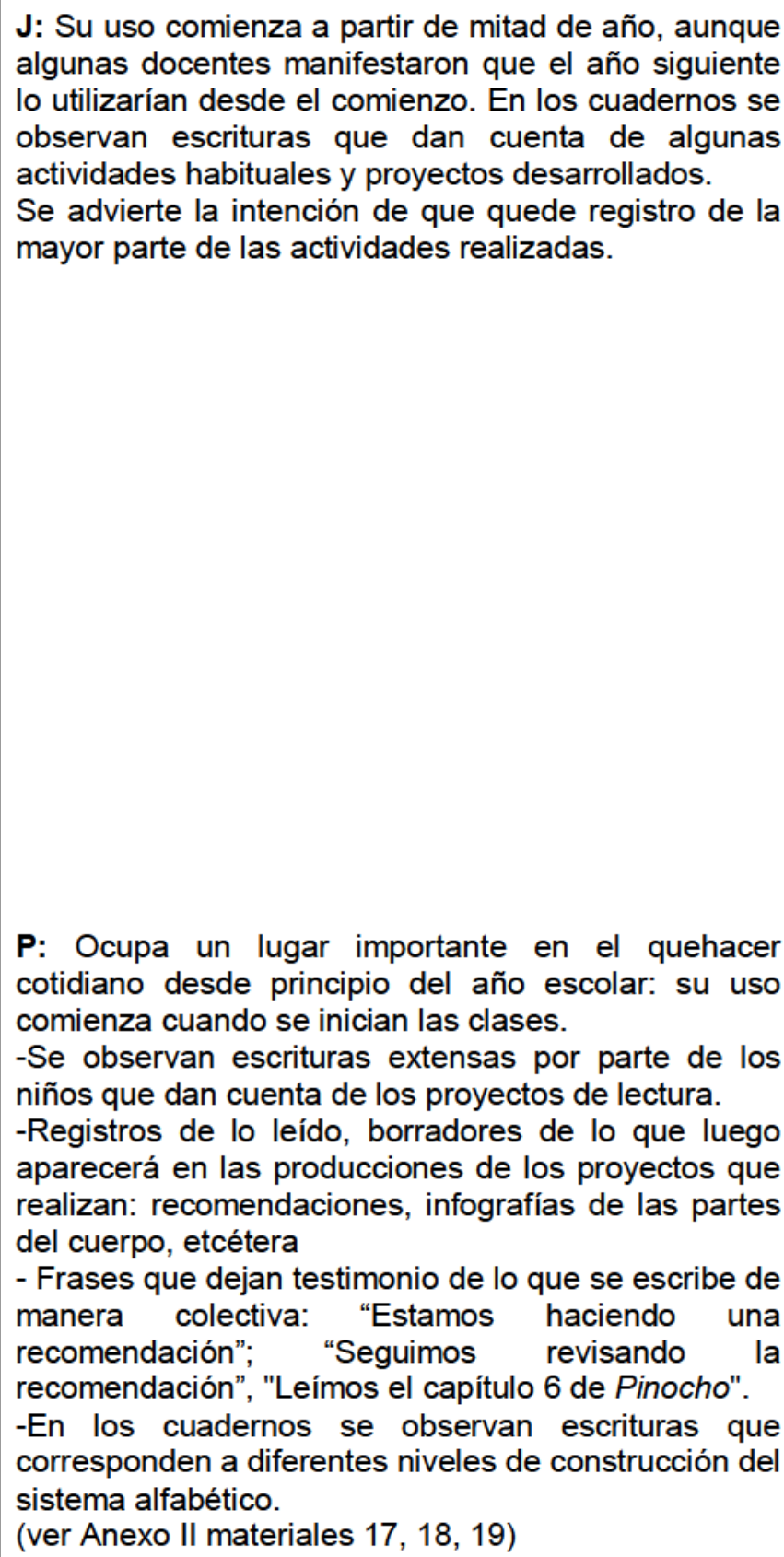 \\
\hline
\end{tabular}




\begin{tabular}{|c|c|}
\hline \multicolumn{2}{|c|}{ INTERVENCIONES del DOCENTE } \\
\hline ESCUELAS X & ESCUELAS Z \\
\hline $\begin{array}{l}\text { - Docente que valida rápidamente y como única } \\
\text { fuente de validación. } \\
\text { J: Si los niños no responden correctamente suelen } \\
\text { alargar la palabra, decir la mitad de la palabra para } \\
\text { que los niños completen. } \\
\text { P: Especial intervención en la corrección del } \\
\text { cuaderno de clase. Es individual y diferida de la } \\
\text { situación de escritura. }\end{array}$ & $\begin{array}{l}\text { - Intervenciones docentes diversas en función de la } \\
\text { situación, según sea de situaciones de lectura, de } \\
\text { escritura y si se realiza, por sí mismos, en pequeños } \\
\text { grupos o en forma colectiva. } \\
\text { - Propone reflexionar sobre lo leído y los diferentes } \\
\text { puntos de vista que puede suscitar un texto. } \\
\text {-Informa, propone contraejemplos, solicita justificación, } \\
\text { incentiva la interacción entre pares y con variadas } \\
\text { fuentes de conocimiento. } \\
\text { - Garantiza la circulación de saberes en la clase. } \\
\text {-Plantea situaciones que implican desafíos cognitivos. }\end{array}$ \\
\hline
\end{tabular}

\begin{tabular}{|c|c|}
\hline \multicolumn{2}{|c|}{ INTERACCIÓN ENTRE LOS NIÑOS } \\
\hline ESCUELAS X & ESCUELAS Z \\
\hline $\begin{array}{l}\text { - Escasas propuestas que promueven la interacción } \\
\text { entre pares en la resolución de tareas de lectura y } \\
\text { escritura. Las actividades son colectivas o } \\
\text { individuales. } \\
\text { - El docente instalado como único informante. }\end{array}$ & $\begin{array}{l}\text { - Promoción del intercambio entre pares y con el } \\
\text { docente, previstas desde la planificación. } \\
\text { - Propuestas enmarcadas en proyectos de trabajo, que, } \\
\text { según la ocasión, son individuales, en parejas, en } \\
\text { pequeños grupos y también de manera colectiva, } \\
\text { durante las puestas en común. } \\
\text { - Actividades de co-corrección en parejas. }\end{array}$ \\
\hline
\end{tabular}

\subsubsection{Situaciones experimentales de recolección de datos}

Se diseñaron situaciones potencialmente aptas para poner de manifiesto las ideas de los niños al finalizar el año escolar. El método de indagación está inspirado en el método clínico crítico. Siguiendo los lineamientos de la psicología genética las tareas suponían una interacción entre el sujeto y el objeto (libro/libros) bajo la forma de una situación a resolver.

Las tareas fueron iguales en las Salas de 5 años y Primer Grado. Los niños indagados en esta Tesis forman parte de una investigación más amplia.

Se incluyeron en el diseño de investigación tareas de búsqueda y localización y otras destinadas a obtener información sobre la cultura escrita: conocimiento acerca del objeto libro, títulos, autores, editoriales, etc. y diferenciación entre géneros. También se han realizado tareas relativas a la escritura de palabras y de conocimiento de las letras y sus variantes tipográficas.

Las trece situaciones fueron las siguientes: 


\begin{tabular}{|l|l|}
\hline \multicolumn{1}{|c|}{ Primera entrevista } & \multicolumn{1}{c|}{ Segunda entrevista } \\
\hline 1) Escritura del nombre propio. & 8) Escritura del nombre propio. \\
2) Escritura por sí mismo de una lista de & 9) Corrección de un texto ajeno. \\
palabras. & 10) Exploración de libros: cuento y \\
3) Lectura de un texto que se sabe de & enciclopedia. Búsqueda de información \\
memoria y reconocimiento de palabras. & específica. Localización por parte del niño \\
4) Lectura de dos palabras, copia y escritura & del sector donde dice sobre abejas. \\
de un texto a partir de imágenes. & Anticipación de las características de un \\
5) Lectura de palabras. & cuento y una enciclopedia. \\
6) Lectura de palabras en un índice. & 11) Tareas de omisión del primer fonema. \\
7) Lectura de inicios de cuentos para decidir & 12) Transformaciones de palabras \\
cuál es cuál. & 13) Conocimiento de letras. \\
\hline
\end{tabular}

Estas tareas fueron propuestas a los niños de manera individual, distribuidas en dos entrevistas administradas en un lapso no mayor a dos semanas. Cada entrevista duró entre 45 minutos y 1 hora de acuerdo al tiempo utilizado por cada niño para realizarla y fueron efectuadas en las instalaciones escolares. Se grabaron en audio y se registraron manualmente en notas de campo. Con ambos materiales y las producciones escritas por los niños se elaboró un registro integrado.

\subsubsection{Descripción del material utilizado en las situaciones analizadas en la presente Tesis}

Se pensaron en situaciones experimentales estructuradas pero flexibles que nos permitiera ir descubriendo las hipótesis que los niños ponen en juego a raíz de cada una de las propuestas.

Las dos situaciones que analizamos en esta Tesis corresponden a la tarea 10: "Anticipación de las características de un cuento y una enciclopedia. Exploración de libros: cuento y enciclopedia. Búsqueda de informaron específica. Localización por parte del niño del sector donde dice sobre abejas." En ellas se pedía identificar la enciclopedia y localizar información específica. El material presentado consistía en un cuento: "La abeja Haragana" y una enciclopedia: "El insólito reino de los insectos".

La realización de tomas preliminares permitió definir los libros más fecundos para formular mejores preguntas, que nos permitieran obtener datos sobre las posibilidades de lectura e interpretación de este tipo de material. Fue ardua la tarea de búsqueda de los materiales. Era necesario que cada uno de los libros representara adecuadamente a los libros del género pero, además, que tuvieran algo en común que fuera un problema desafiante para los niños en la búsqueda y localización de información. En los dos libros escogidos, "las abejas" están presentes. 

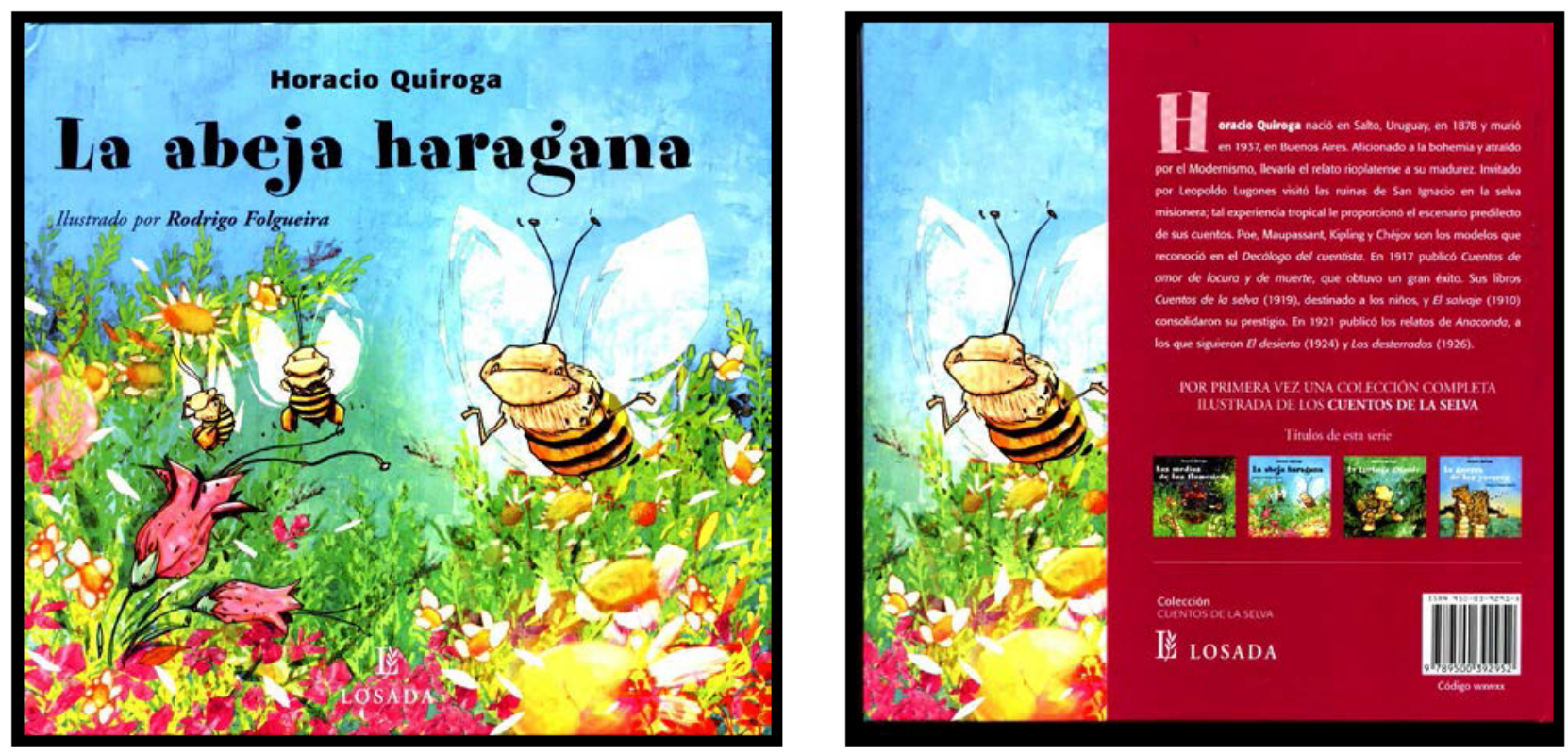

Cuento

"La abeja Haragana"

Horacio Quiroga

Editorial Losada
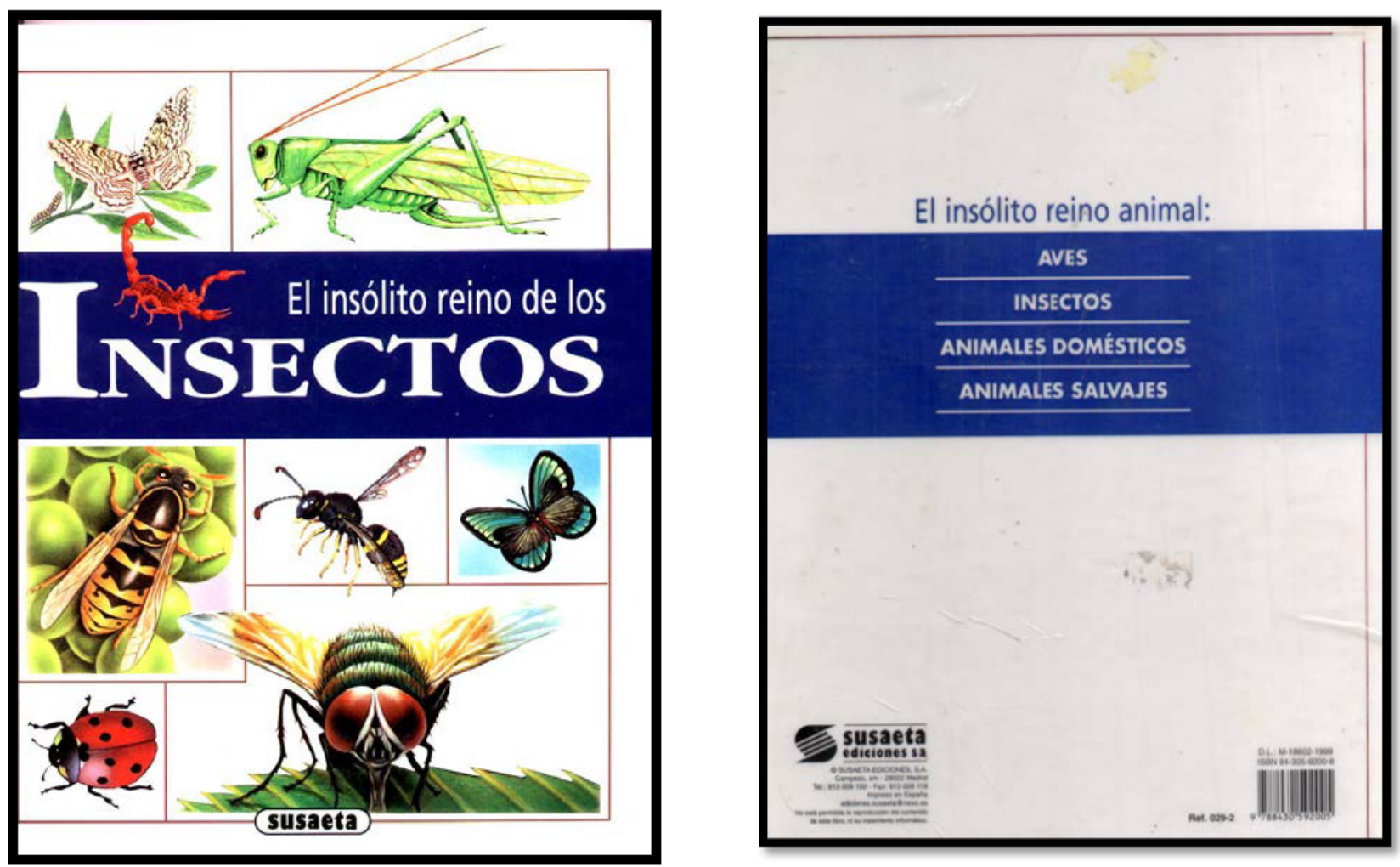

Enciclopedia infantil

"El insólito reino de los insectos"

Editorial Susaeta 
La enciclopedia no está dirigida especialmente a niños pequeños y resguarda las características de dichos textos. El cuento es de un autor consagrado en una edición diferente a la original pero el texto es el mismo.

Ambos portadores cuentan con imágenes de tapa que ilustran abejas según rasgos de edición canónicos para este tipo de materiales: dibujos realistas para el texto informativo y no realistas para el ficcional, ambos en color. En dichos libros la tipografía utilizada en el cuerpo del texto es imprenta minúscula de igual tamaño y cada uno respeta una diagramación característica de los libros del género.

La cantidad y diversidad de información que podíamos recoger durante la exploración y localización de información de la enciclopedia requería de un instrumento que nos permitiera recuperar con mayor precisión los señalamientos de los pequeños. Para ello hemos utilizado, en el momento de las entrevistas, grabaciones de audio y, además, fotocopias de las páginas de las avispas y abejas para poder indicar con precisión qué decían y dónde señalaban cada uno de los 122 niños entrevistados (Anexo III).

En los capítulos III y IV se especifican otras particularidades de ambos libros.

\subsubsection{Situación 1: Identificar el libro "para saber más sobre las abejas"}

Esta tarea indaga cuál es la elección infantil cuando el propósito se vincula con la búsqueda de información específica sobre un tema -en este caso las abejas- y en función de qué datos o argumentos justifican su elección.

A la lista de información no visuales de Smith (1980 véase marco teórico) se agrega uno esencial: la identificación del soporte material del texto: aún antes de que comencemos a leer ya se sabe algo del texto en virtud de las categorización que se haya hecho de su soporte material (Ferreiro, E. 1979. Pág. 346). La oportunidad para desarrollar y emplear la predicción debe ser una parte esencial del aprendizaje de la lectura.

En la mesa, frente al niño, se encontraban los dos libros descriptos. El investigador preguntaba:

¿¿En qué libro te parece que hay que fijarse para saber más sobre las abejas, para aprender sobre las abejas"?

En caso de que el niño no tomara el libro o no lo abriera el entrevistador le sugería:

"Podes fijarte adentro del libro a ver si hay algo sobre las abejas". 
Frente a cada una de las intervenciones analizamos qué hacían los niños, qué miraban más detenidamente, qué comentaba mientras buscaban, cómo justificaban sus elecciones, qué datos de los libros tomaban en cuenta, etcétera,

Luego de esta tarea se proponía la siguiente y se dejaba en la mesa sólo el libro enciclopédico.

\subsubsection{Situación 2: Localizar información específica en una enciclopedia}

Esta situación consistía en localizar específicamente en qué páginas de la enciclopedia se encontraba la información sobre las abejas. Nos interesaba investigar cómo hacían los niños para encontrarla y cómo justificaban su elección.

Más allá de cuál hubiera sido la elección en la tarea anterior, se les proponía a continuación trabajar con la enciclopedia. Retirábamos de la mesa el cuento.

Al comienzo de la entrevista, el investigador mostraba el libro cerrado en la mesa y le decía al niño:

"Acá hay información sobre las abejas, ¿cómo podemos hacer para encontrarla?"

Se les brindaba el tiempo necesario para que explorasen y buscasen la información solicitada. El investigador observaba y registraba las distintas decisiones infantiles en el proceso de exploración del material, todos sus señalamientos y verbalizaciones. En el caso de que los niños no justificaran su elección, el investigador se lo solicitaba:

"¿Cómo te diste cuenta de que aquí (donde había señalado el niño) dice sobre las abejas?

Mostrame con el dedo dónde te fijaste para saber si dice algo sobre las abejas".

Es importante aclarar que tomamos la decisión de preguntar "dónde dice sobre las abejas" y no "dónde dice 'abejas"” porque consideramos que el primer enunciado es más amplio ya que incluye diversas informaciones, a diferencia del segundo que restringe la búsqueda a la localización de una palabra.

Si el niño remitía solo a las imágenes, se le preguntaba:

“¿Hay otro lugar en que puedas fijarte aparte de los dibujos?"

Si el niño no tomaba en cuenta lo escrito, la pregunta era más específica:

"Si nos tuviéramos que fijar donde está escrito, ¿en qué parte te fijarías para saber rápido si dice algo sobre las abejas?" 
Una vez que el niño decidía su elección, el investigador planteaba contraejemplos para promover la reflexión de los niños acerca de su decisión y poder así verificar la estabilidad de sus respuestas, comprobando si cambiaban de parecer o sostenían lo escogido ${ }^{5}$.

- Si el niño señalaba la imagen de las abejas, se le mostraba la página de las avispas comentando: "Otro nene me dijo que podía ser en ésta" (avispas).

- Si el niño se detenía en la página de las avispas, se le mostraba la página de las abejas comentando: "Otro nene me dijo que podía ser en ésta (abejas) acá hay un dibujo parecido..."

- Si el niño se detenía en las letras de ABEJAS ${ }^{6}$, se le mostraba AVISPAS y se le decía que allí también había algunas letras de "abejas".

- Si el niño se detenía en las letras de AVISPAS, se le mostraba ABEJAS, y se le decía que allí también había algunas letras de "avispas".

- Si el niño decía "en las dos páginas", se le decía: "solo una dice sobre las abejas" y se le preguntaba cuál.

En todos los casos se les solicitaba justificación de sus respuestas.

Al igual que en la tarea anterior, frente a cada una de las consignas resgitramos qué hacían los niños, cómo justificaban sus elecciones, qué índices del texto y/o del paratexto tomaban en consideración, qué informaciones podían coordinar para anticipar y corroborar esas anticipaciones, como así también si la elección final coincidía o no con la inicial.

En los capítulos siguientes se analizan los datos obtenidos a partir de las entrevistas realizadas. En ambos se presentan a modo de ejemplo extractos de protocolos ilustrativos de los diferentes tipos de respuestas encontradas.

\footnotetext{
${ }^{5}$ Véase "contraargumentación", en el marco teórico.

${ }^{6}$ En adelante, ABEJAS y AVISPAS en esta tipografíaa hace referencia a los títulos correspondientes.
} 


\section{CAPÍTULO III \\ IDENTIFICAR EL LIBRO \\ "PARA SABER MÁS SOBRE LAS ABEJAS"}

\section{Introducción}

Es relevante para esta investigación conocer qué saben los niños respecto de libros de géneros distintos: una enciclopedia y un libro de cuentos. En el marco de una entrevista de tipo clínicocrítica se mostraba a cada niño dos libros de circulación social: una enciclopedia de animales y un cuento, ambos con imágenes de abejas en la tapa. Consecuentemente, en la tarea encadenada administrada, se les preguntó cuál de los dos libros cumplía, para ellos, con la consigna dada por el entrevistador.

La consigna se presentaba en condiciones particulares: los dos libros dispuestos sobre la mesa, cerrados y con las tapas hacia arriba; se brindaba, además, el tiempo necesario para que los niños entrevistados pudieran tomarlos, hojearlos, explorarlos para realizar su elección y justificarla.

En este capítulo analizamos las elecciones que los niños realizaron así como las justificaciones dadas para determinar dicha elección.

\subsection{Descripción de la situación experimental}

Esta tarea indaga cuál es la elección infantil cuando el propósito se vincula con la búsqueda de información específica sobre un tema -en este caso las abejas- y en función de qué datos o argumentos justifican su elección. La elección correcta es, lógicamente, la enciclopedia.

Las preguntas e intervenciones del investigador fueron:

"¿En qué libro te parece que hay que fijarse para saber más sobre las abejas, para aprender sobre las abejas"?

En caso de que el niño no tomara el libro o no lo abriera el entrevistador le sugería:

"Podes fijarte adentro del libro a ver si hay algo sobre las abejas".

[49] 
Frente a cada una de las consignas analizamos qué hacían los niños, cómo justificaban sus elecciones, qué índices del texto y/o del paratexto tomaban en consideración, como así también qué informaciones podían coordinar para anticipar y corroborar esas anticipaciones.

\subsection{Descripción de los libros utilizados}

Se han utilizado para esta tarea -como señalábamos en el Capítulo II- dos libros: un cuento: "La abeja haragana" y una enciclopedia: "El insólito reino de los insectos".

Ambos portadores cuentan con imágenes de tapa que ilustran abejas según rasgos de edición ajustados a este tipo de materiales: dibujos realistas para el texto informativo y no realistas para el ficcional, ambos en color. La tipografía utilizada en el cuerpo de los textos es imprenta minúscula de igual tamaño y cada uno respeta una diagramación característica de los libros del género. La enciclopedia no está dirigida especialmente a niños pequeños. El cuento es de un autor consagrado en una edición diferente a la original pero el texto es el mismo ${ }^{1}$.

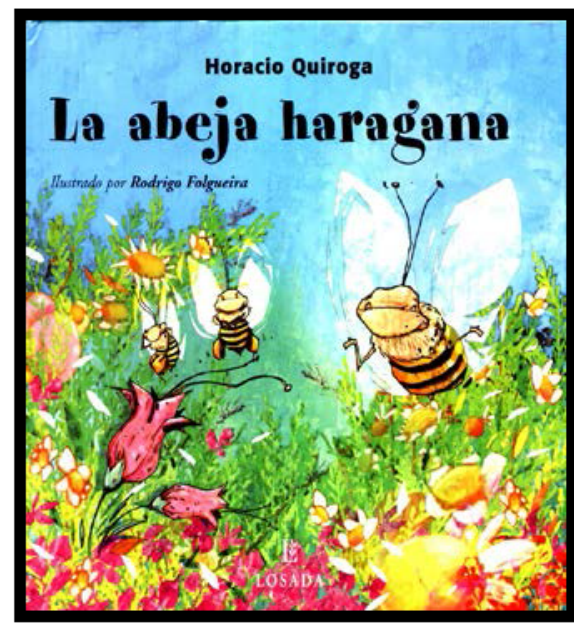

Cuento

"La abeja haragana" Horacio Quiroga Editorial Losada

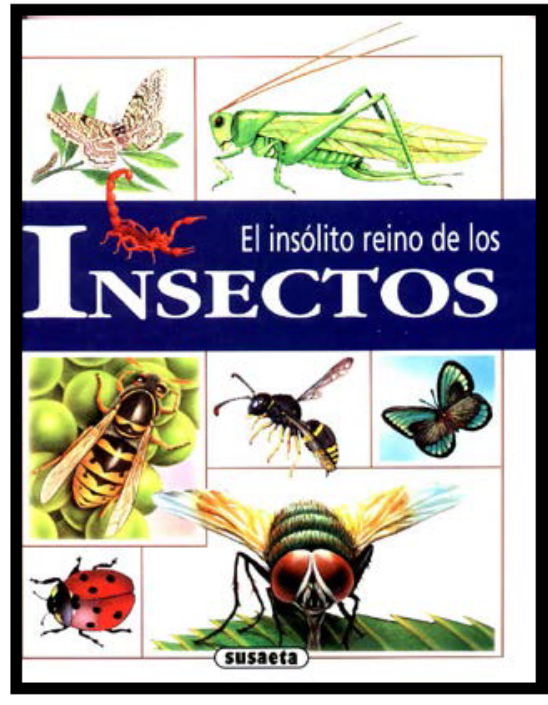

Enciclopedia infantil "El insólito reino de los insectos" Editorial Susaeta

La enciclopedia posee un índice y en sus páginas hay títulos, subtítulos, textos descriptivos, imágenes y epígrafes. Dispone de información sobre diferentes insectos: hormigas, chinches, cucaracha, avispas, escorpiones ${ }^{2}$, cigarras, mantis, langostas, moscas, abejas, mariquitas,

\footnotetext{
${ }^{1}$ La versión original de "La abeja haragana" forma parte de Cuentos de la selva de Horacio Quiroga publicado por primera vez en 1918.

${ }^{2}$ De acuerdo a la clasificación científica, los escorpiones no son insectos. Si bien pertenecen junto a los insectos a un grupo más amplio - el de los artrópodos- los escorpiones son en realidad arácnidos. A pesar de este error frecuente en
} 
mariposas. La información de cada insecto ocupa dos páginas. Se organiza a partir de un título en letra imprenta mayúscula (grande y con letras separadas). En el cuerpo del libro hay varios subtítulos en imprenta mayúscula/minúscula, algunos forman parte de recuadros. Contiene -entre otros- dos insectos parecidos en su fisonomía: las abejas y las avispas. La escritura de los nombres es similar y esto constituye un problema añadido para los niños: las palabras comparten la letra inicial y las dos finales, las segundas letras de cada palabras ( $V \circ \mathrm{B})$-si bien son diferentes desde el punto de vista gráfico-poseen identidad fónica y la cantidad de letras en ambas palabras es muy pareja (seis y siete). "Avispas" se encuentra primero en el libro (págs. 12 y 13) y "Abejas", hojas más atrás (págs. 24 y 25). "Avispas" y "abejas" presentan ilustraciones similares, motivo por el cual favorece la posibilidad de intervención del Investigador (Como se desarrolla en el capítulo IV).

El cuento, "La abeja haragana", comienza con una frase de inicio canónico para el género "Había una vez", la "H" -en letra capital y color que la diferencia del resto- ocupa un importante espacio en la primera página. El cuento tiene texto en casi todas las páginas e importantes ilustraciones a color donde los dibujos de abejas son los predominantes.

\subsection{Elección del libro "para saber más sobre las abejas"}

Cuando se solicitó a los niños que decidieran en cuál de los dos libros se podía encontrar información sobre las abejas, las respuestas se distribuyeron - como era esperable - entre las que optaban por la enciclopedia y las que seleccionaban el cuento. Varios niños no lograron tener certeza acerca de cuál de los dos era el adecuado y no pudieron efectuar la tarea. Los datos se distribuyen, entonces, de la siguiente manera:

1) Elección pertinente del material según propósito enunciado: enciclopedia (Enciclopedia

$+)$

2) Elección no pertinente del material según propósito enunciado: cuento (Cuento -).

3) No selecciona material.

libros destinados a niños, hemos decidido incorporar el material por su adecuación a los propósitos de esta investigación. 


\subsubsection{Distribución de las respuestas en función de la elección del libro en el total de los niños estudiados}

Los porcentajes de las respuestas son los siguientes:

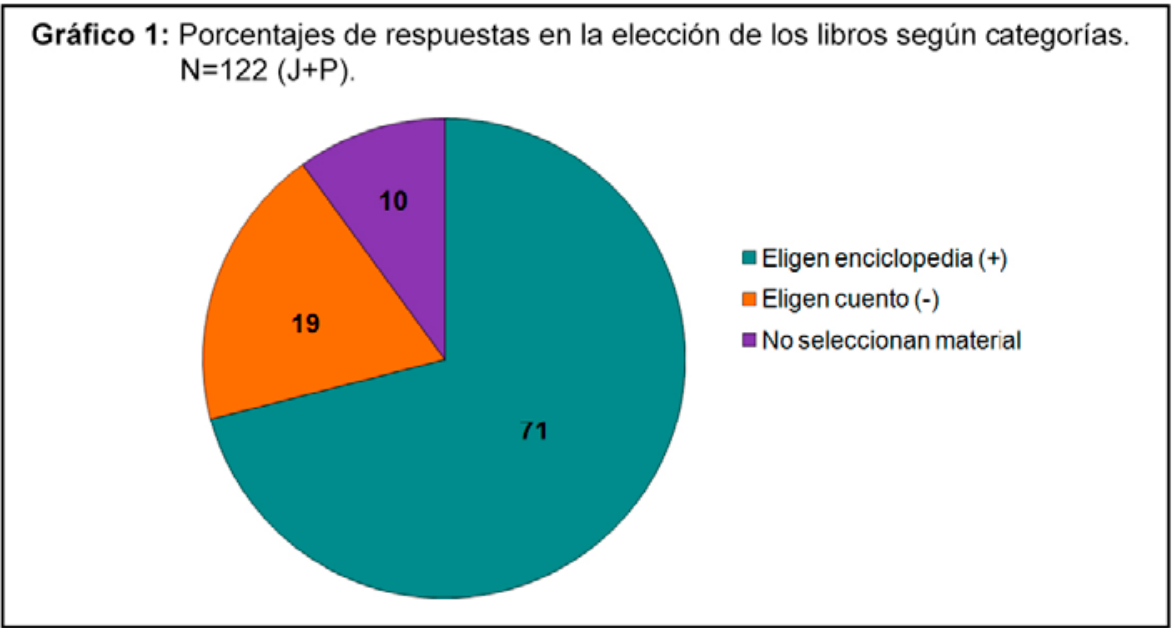

Como puede observarse un $10 \%$ de la muestra, 12 niños, no logra efectuar ninguna elección, el otro $90 \%$ logra elegir uno de los dos materiales presentados, independientemente de que las respuestas sean pertinentes o no (110 respuestas que coinciden con la cantidad de niños). De ese $90 \%$ de la muestra que realizó la elección, un $71 \%$-constituido por 87 niños- respondió adecuadamente y un $19 \%$-que corresponde a 23 niños - brinda respuestas no pertinentes (elección del cuento).

Estos datos constatan lo que hemos expuesto en el Capítulo / respecto de que los niños desde pequeños poseen conocimientos sobre los géneros.

Como este trabajo, además, se propone contrastar las respuestas entre niveles de escolaridad y escuelas con prácticas de enseñanza diferentes cuando los niños seleccionan un libro en función de un propósito determinado y analizar las justificaciones brindadas en el Gráfico 2, (en 3.3.2) se despliega cómo se distribuyen los porcentajes de respuestas en relación a la elección del libro según nivel de enseñanza y tipo de escuelas. 
3.3.2. Distribución de las respuestas según nivel de escolaridad y tipo de escuelas a las que asisten (X y Z)

En primera instancia podemos advertir que las Escuelas $\mathrm{X}$ muestran un porcentaje mayor de niños que no lograron concretar su elección que las Escuelas Z.

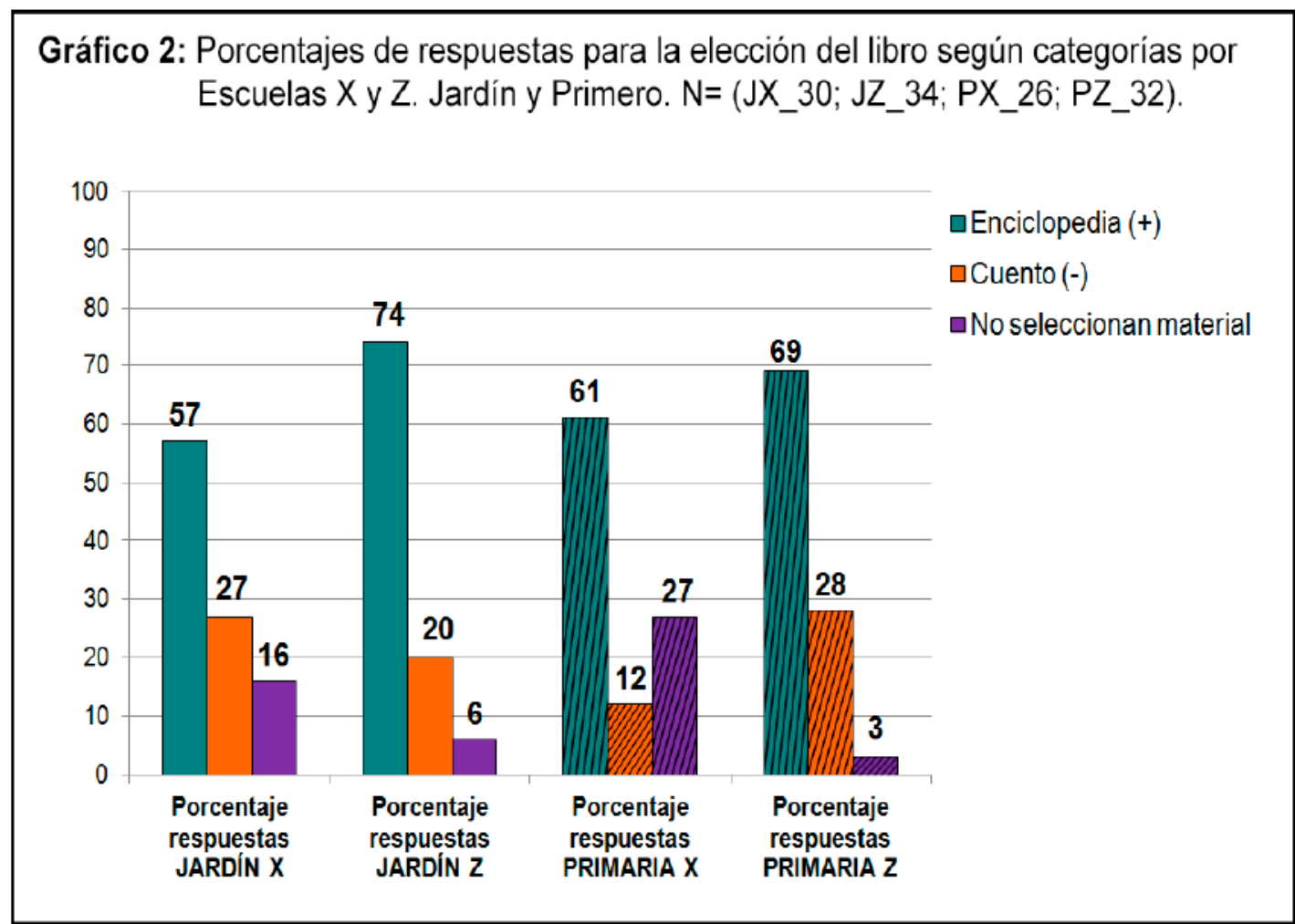

Si comparamos los dos grupos de Jardín, podemos observar que un $74 \%$ de las respuestas de Jardín Z son adecuadas, mientras que, en el Jardín X, este porcentaje no es tan elevado: $57 \%$.

El porcentaje de respuestas no pertinentes difiere de manera menos significativa: $27 \%$ en JX y $20 \%$ en los JZ.

En cuanto a los niños que no seleccionan ningún material, solo el $6 \%$ de las respuestas corresponde al Jardín Z, mientras que este número asciende al $16 \%$ en las X.

En Primer Grado, los porcentajes de respuestas adecuadas son bastante cercanos entre las diferentes escuelas: $69 \%$ en las Escuelas $Z$ y $61 \%$ en las $X$.

En cuanto a los porcentajes correspondientes a los niños que no se deciden por ninguno de los dos libros expuestos, la diferencia es muy notable: en las Escuelas X asciende al $27 \%$ de las respuestas mientras que, en las $Z$, es tan solo de un $3 \%$. 
En este puntos nos referimos a los porcentajes de respuesta respecto a la elección. En el siguiente apartado analizaremos las diversas justificaciones que brindan los niños al momento de elegir el libro.

\subsection{Justificaciones de la elección efectuada}

En primer lugar, seleccionaremos las respuestas que se analizarán en este ítem, categorizaremos las justificaciones, expondremos su distribución en los diferentes grupos de escuela y niveles de escolaridad y, por último, analizaremos las verbalizaciones de los niños en cada una de las categorías descriptas.

\subsubsection{Selección de las respuestas para el análisis de las justificaciones}

En el Gráfico 1, como se señaló en el punto 3.3.3. se ilustra la distribución del total de los niños estudiados en función de su elección. Aparece allí un $71 \%$ de respuestas acertadas, un $19 \%$ que selecciona el cuento y un $10 \%$ que no selecciona ninguno de los textos.

Como nos interesa analizar qué elementos toman en cuenta para decidir su elección los niños que todavía no leyeron convencionalmente los títulos de las tapas de los libros, en el Gráfico 3 desagregamos las respuestas a fin de precisar la población sobre la que trabajaremos para analizar las justificaciones.

Gráfico 3: Porcentaje de las justificaciones esgrimidas $\mathrm{N}=122$.

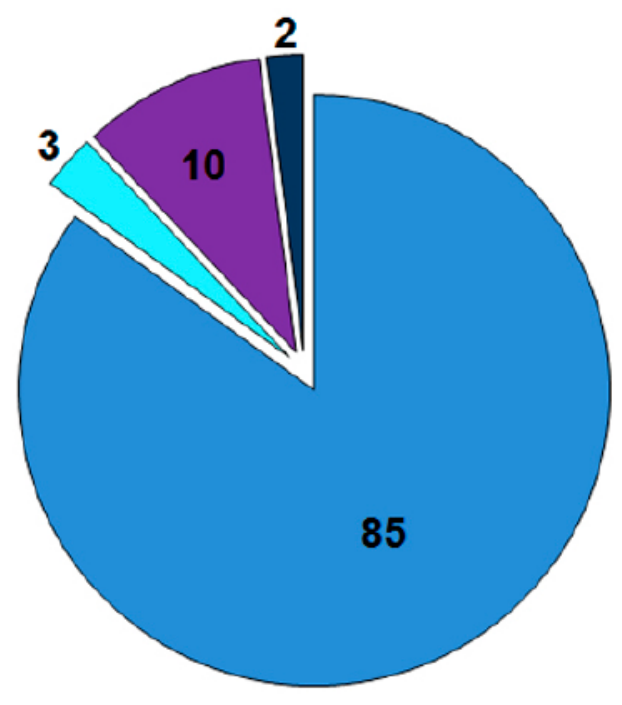

$\square$ Justifican la elección

$\square$ No justifican la elección

- No seleccionan el material

- Leen de manera convencional 
Como en este ítem analizaremos las justificaciones, quedan excluidos los niños que no lograron llegar a una elección, que aparecían también en el Gráfico 1 (10\%), los que eligieron pero no verbalizaron ninguna justificación (3\%), como así también las respuestas de los alumnos que seleccionaron bien el texto enciclopédico en función de leer convencionalmente (2\%). Por esta razón, tomamos en cuenta para el análisis las restantes 103 respuestas que constituyen el $85 \%$ del total.

Si bien no tomaremos en consideración el 15\% ya mencionado, que corresponde a 19 respuestas, señalaremos en qué escuelas y en qué nivel de escolaridad se encuentran esos niños.

Tres de esos niños, que asisten a Primer Grado, leen de manera convencional el título de la Enciclopedia. Uno asiste a una de las Escuelas X y los otros dos a Escuelas Z. Los dos niños de Primero $Z$ toman varios recaudos para asegurarse de que la enciclopedia sea el libro adecuado. Manuel toma el libro, lo va hojeando cuidadosamente, se detiene en la página 25 que corresponde a las abejas, se detiene, lee los dos primeros párrafos y dice: "Este es para saber sobre las abejas".

María de los Ángeles, también de Escuela Z, hojea ambos libros, lee el título de la enciclopedia, luego hojea y lee el título del cuento. Vuelve a la enciclopedia y dice: "Este tiene cosas de los animales, qué cosas podés conocer de ellos".

A diferencia de los anteriores, Álvaro, de Primero X, lee el título "in-sec-tos" y pareciera no necesitar más justificación para decidirse. Está claro que este niño identifica a las abejas como un insecto.

Los cuatro niños que eligen la enciclopedia sin verbalizar ninguna justificación, a pesar de las preguntas del entrevistador, asisten a Primer Grado X.

Los doce niños restantes son los que no realizan una elección sostenida a pesar de que, por momentos, señalen un libro o el otro. Cuando se les pregunta por qué consideraban que ese libro es "para saber sobre las abejas", responden con comentarios tales como "porque sí", "porque me gusta", "porque es lindo". Los mismos comentarios podían ser trasladados al otro libro pero sin definirse por ninguno en particular. Seis de ellos asisten a Jardín y los otros seis a Primer Grado. 
En los apartados que siguen, nos centraremos en analizar las justificaciones brindadas por los niños. Recordemos que se trata de 103 niños que corresponden al $85 \%$ del total. Veamos cómo se distribuyen estos alumnos de acuerdo con el nivel de escolaridad y con el tipo de escuelas a las que asisten.

Tabla 1. Cantidad de niños que justifican su elección.

\begin{tabular}{|c|c|c|c|c|c|}
\hline Escuelas & JX & JZ & PX & PZ & Total \\
\hline Niños entrevistados por escuela & 30 & 34 & 26 & 32 & 122 \\
\hline Niños que justifican su elección & 26 & 32 & 16 & 29 & 103 \\
\hline
\end{tabular}

Consideraremos el total de niños en cada institución. Advertimos, entonces, que en ambos tipos de jardines ( $X$ y $Z$ ) la mayoría de los niños logra justificar ( $X=26$ sobre 30; $Z=32$ sobre 34). La diferencia entre ambos tipos de instituciones es poco relevante: en los Jardines $X, 4$ niños no logran justificar y en los Jardines Z, 2 niños no lo hacen. Sin embargo, en Primer Grado, la diferencia entre los que justifican y lo que no lo hacen en una y otra institución es notable. Mientras que en Primero $X$ hay 10 niños que no verbalizan ninguna justificación, en Primero $Z$ esto sucede con un solo alumno, ya que los otros dos fueron excluidos porque leían convencionalmente.

\subsubsection{Análisis de la distribución de los diferentes tipos de justificaciones de la elección efectuada}

El análisis de los datos nos permitió categorizar las respuestas en función de qué aspectos tomaron en cuenta los niños para justificar su elección:

- Justificaciones que sólo atienden a las ilustraciones.

- Justificaciones que ponderan algunas características materiales de los dos libros.

- Justificaciones que toman en cuenta ciertos rasgos específicos de los textos literarios y/o de los enciclopédicos. 


\subsubsection{Distribución en el total de los niños estudiados}

En el Gráfico 4 se presentan los tipos de respuestas y los porcentajes de las mismas.

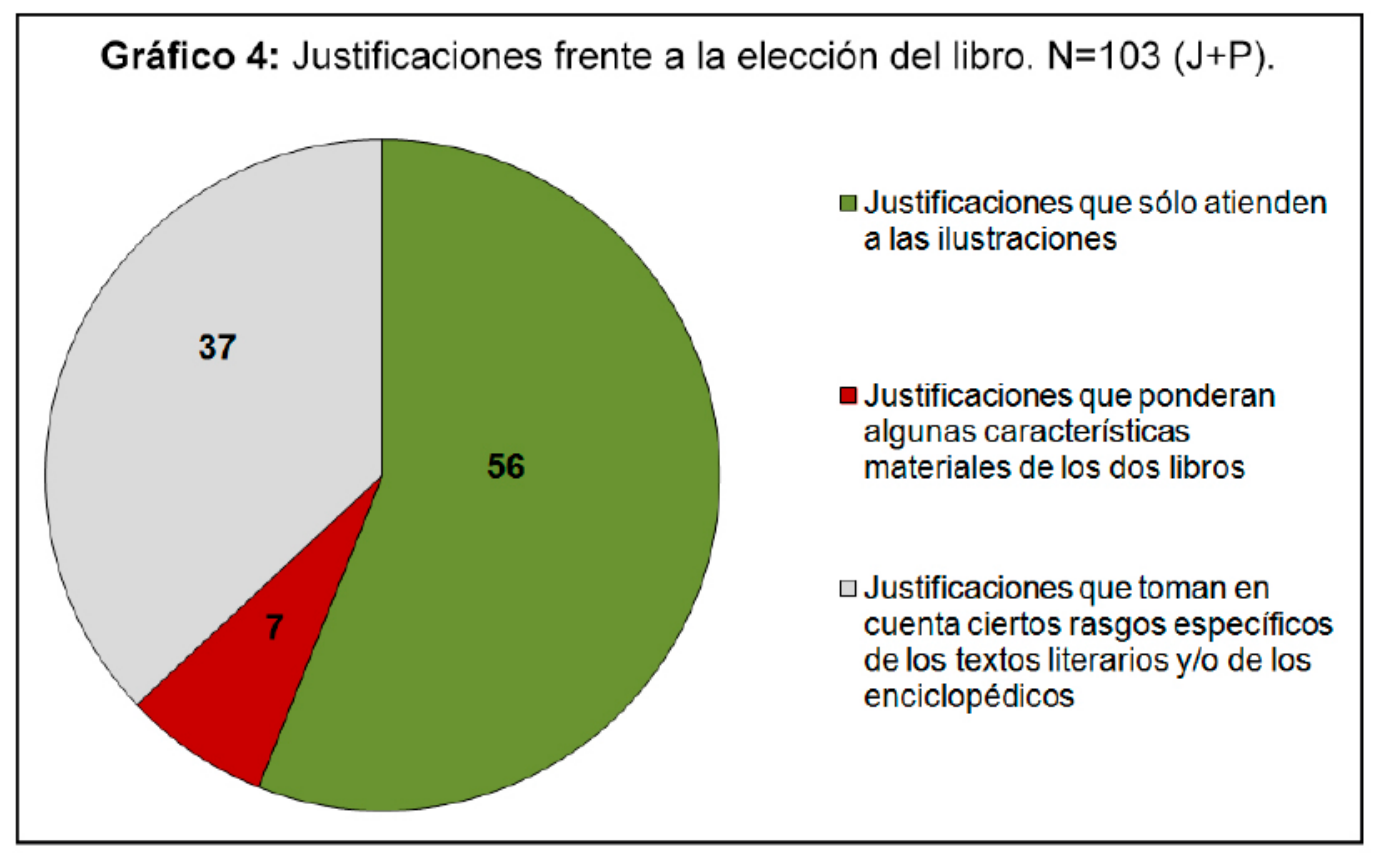

Como se observa, más de la mitad de las justificaciones (56\%) aluden a aspectos de las ilustraciones. El 7\% realiza justificaciones que ponderan algunas características materiales de los dos libros y un $37 \%$ menciona justificaciones que toman en cuenta ciertos rasgos específicos de los textos literarios y/o enciclopédicos.

Estos porcentajes corresponden al total de los niños, observemos qué pasa si los diferenciamos por tipo de escuela y nivel de escolaridad. 
3.4.2.2. Distribución según nivel de escolaridad y de tipo de escuelas a las que asisten ( $X$ y $Z)$

El Gráfico 5 pone de manifiesto la distribución de las justificaciones en Jardín y Primer Grado.

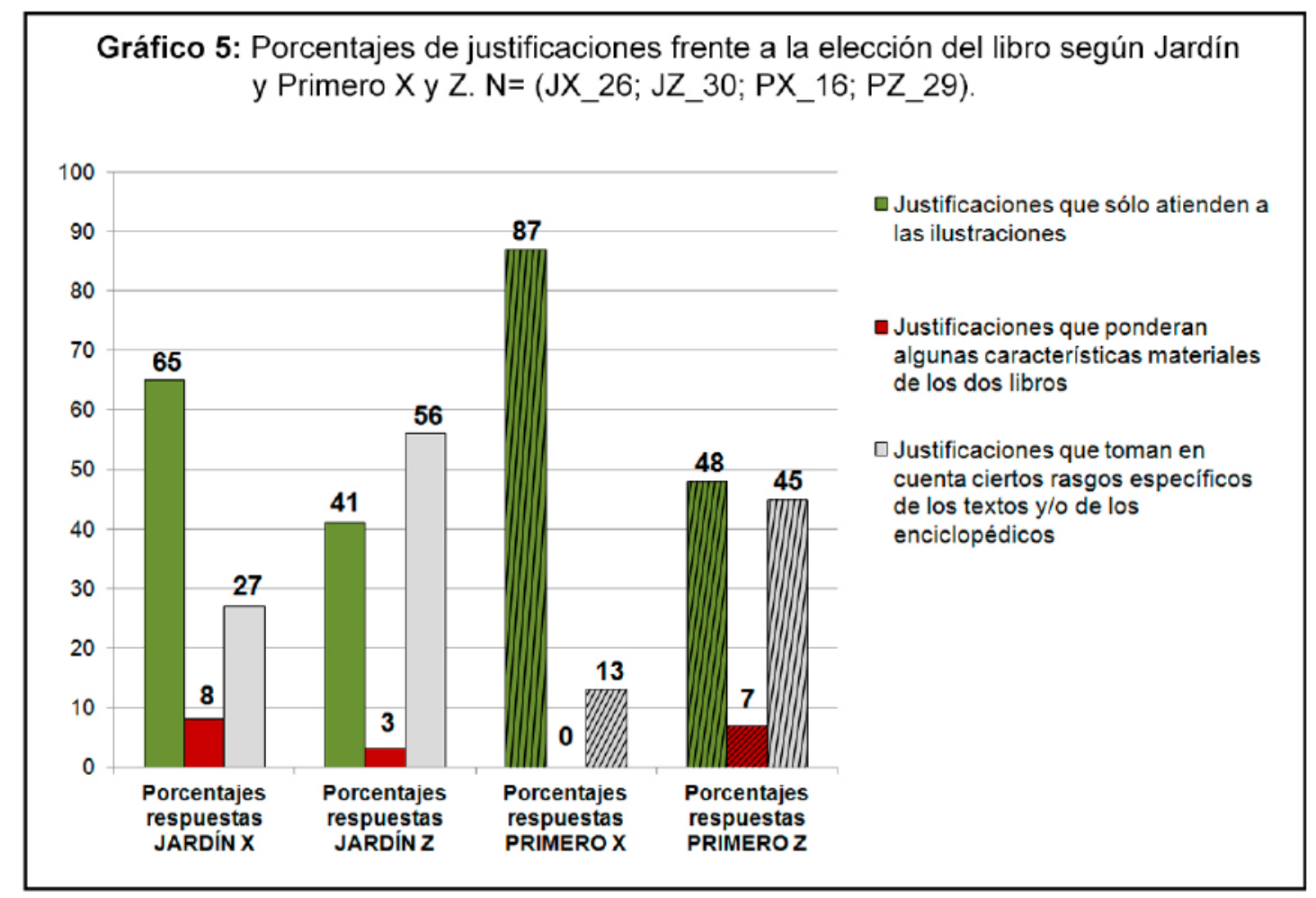

La mayoría de los niños apela a las ilustraciones para justificar su elección. Advertimos que las Escuelas X concentran el porcentaje mayor: en Jardín el 65\% y en Primer Grado el $87 \%$.

Si observamos las "Justificaciones que ponderan algunas características materiales de los dos libros", advertirnos que no hay importantes diferencias entre los Jardines ( $X=8 \%$ y $Z=3 \%$ ). Sin embargo, en Primer grado la diferencia es mayor entre las Escuelas X (0\%) y las Escuelas Z (7\%).

En las "Justificaciones que toman en cuenta ciertos rasgos específicos de los textos literarios y/o de los enciclopédicos" hay diferencias significativas entre las Escuelas $\mathrm{X}$ y $\mathrm{Z}$ tanto en Jardín como en Primero.

En Jardín X el porcentaje de respuestas es de $27 \%$ y en Jardín Z de $56 \%$.

En Primero, el porcentaje de las $X$ es de $13 \%$ mientras que en las $Z$ asciende al $45 \%$.

Si cruzamos estos datos con los aciertos y desaciertos en la elección podemos observar que todos los niños incluidos en la segunda y la tercera categorías eligieron el libro adecuado (la enciclopedia). En cambio, las respuestas que solo atienden a las ilustraciones incluyen tanto elecciones adecuadas como erróneas. 
En el próximo ítem analizaremos las diferentes justificaciones que brindan los niños.

\subsubsection{Análisis de las verbalizaciones de los niños en cada una de las categorías descriptas}

\subsubsection{Justificaciones que sólo atienden a las ilustraciones}

Hemos advertido un dato peculiar en las justificaciones que brindan los niños cuando sus elecciones se centran en las ilustraciones: esgrimen el mismo tipo de justificación para el cuento o para la enciclopedia.

Señalaremos con un (+) a las justificaciones que atienden a las ilustraciones y eligen la enciclopedia y señalaremos con un (-) a aquellas justificaciones centradas en las ilustraciones que eligen el cuento. Esto sucede tanto en Jardín como en Primer Grado.

En el Gráfico 6 se exponen los datos específicos.

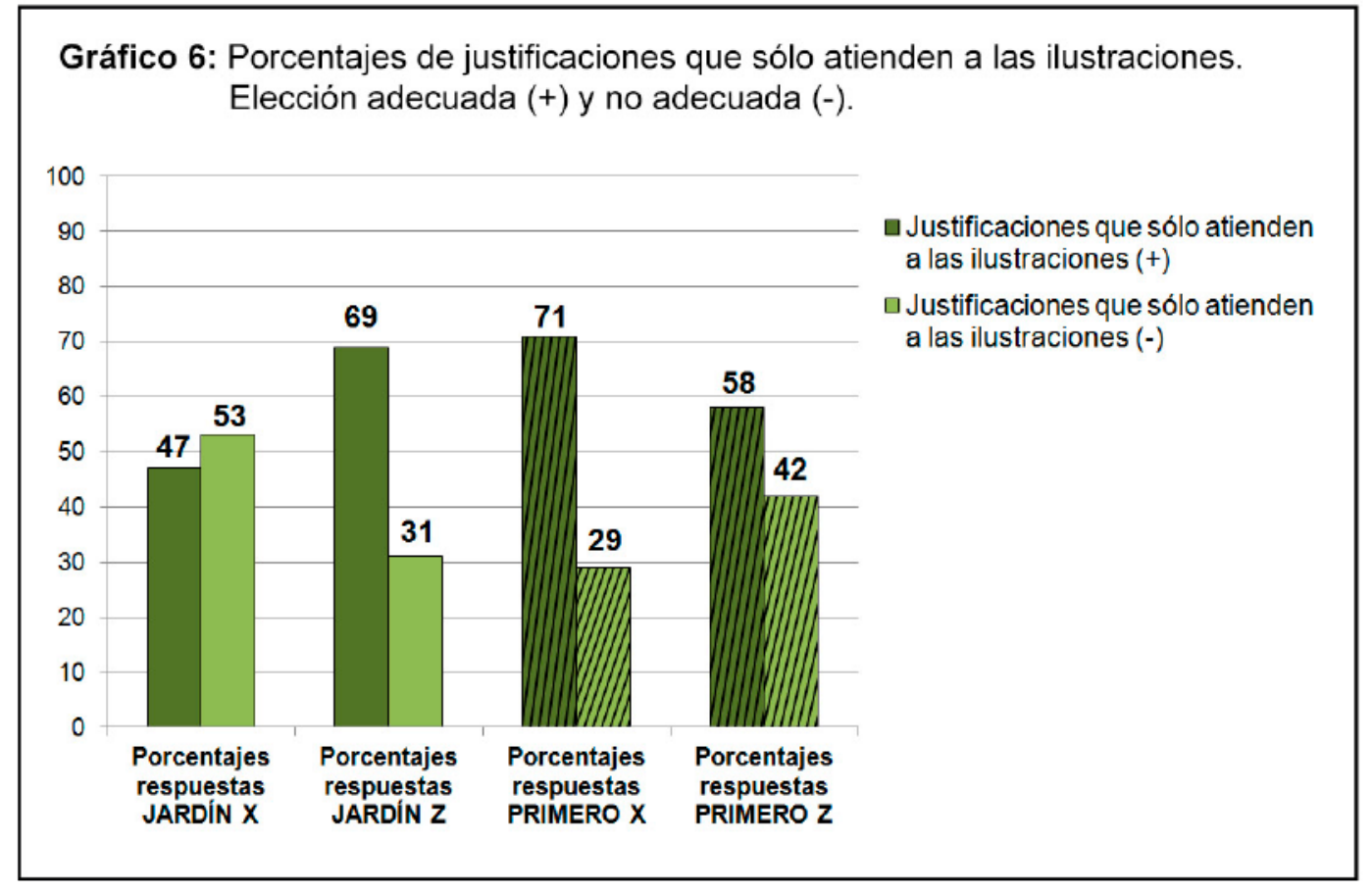

En Jardín se observan diferencias considerables entre $X$ y $Z$, tanto en las elecciones pertinentes como en las no pertinentes. Es posible observar que en $\mathrm{X}$, el porcentaje de elecciones no adecuadas es mayor que el de las correctas, aunque hay poca diferencia entre ambos tipos. En los Jardines Z, en cambio, la mayoría elige la enciclopedia, y aquí, la diferencia entre ambos tipos de respuestas es mayor. 
En Primer Grado de las Escuelas X, el mayor porcentaje corresponde a la elección y se observa una diferencia notable con las no pertinentes. En las Escuelas Z, un porcentaje menor de niños eligió la enciclopedia y un porcentaje mayor el cuento. Es importante recordar que, en el grupo X hay 10 niños que fueron excluidos de este análisis porque no lograron explicitar ninguna justificación, lo que podría estar desvirtuando esta comparación en términos de porcentajes.

Desde la perspectiva cualitativa aparece un dato peculiar: muchos niños que han optado por seleccionar la enciclopedia (+) y otros que han elegido el cuento (-) esgrimieron prácticamente la misma justificación al observar las ilustraciones de tapa.

Es posible advertir que la comparación entre las tapas de los libros puede llevar a los niños a tomar decisiones opuestas en función de justificaciones idénticas.

Varios niños eligen el libro inadecuado - cuento - argumentando que lo hacen porque ese es solo de abejas:

"porque tiene abejas y no tiene nada más"; "porque acá hay solo abejas y acá (señala la enciclopedia) hay abejas y otras cosas".

Curiosamente, otros niños toman el mismo argumento para justificar su elección del libro adecuado - enciclopedia - :

"porque tiene muchos insectos y habla de muchos insectos y acá (señala el cuento) están las abejas nomás"; "porque tiene abejas nomás (rechaza el cuento) en cambio este (enciclopedia) tiene moscos y mariposas, tiene muchos animales".

Otro argumento, verbalizado tanto por quienes escogen el libro adecuado como por los que eligen el cuento, se relaciona con la cantidad de abejas que hay en cada una de las tapas. Que haya más o menos abejas puede servir de justificación para elegir la enciclopedia o el cuento, tal como vemos en los siguientes ejemplos:

\begin{tabular}{|l|l|}
\hline \multicolumn{1}{|c|}{ Eligen el cuento (no adecuado) } & \multicolumn{1}{c|}{ Eligen la enciclopedia (adecuado) } \\
\hline "Porque hay más abejas" JX- Kevin & $\begin{array}{l}\text { "Este tiene mas abejas" (señala en tapa } \\
\text { varios insectos) JZ- Dante }\end{array}$ \\
\hline $\begin{array}{l}\text { "Porque éste (cuento) tiene más abejas y } \\
\text { éste (enciclopedia) tiene dos" JX- Franco }\end{array}$ & $\begin{array}{l}\text { "Acá cuatro (enciclopedia) y acá hay tres" } \\
\text { (rechaza el cuento).JX- Analía }\end{array}$ \\
\hline
\end{tabular}


Este tipo de justificación coincide, en general, con la elección del cuento, lo cual, podría estar facilitado porque en la tapa están dibujadas cuatro abejas.

Los datos desplegados parecen demostrar que la ilustración no es un indicador que garantice una elección adecuada entre los dos libros expuestos.

\subsubsection{Justificaciones que ponderan algunas características materiales de los libros}

Algunas respuestas justifican la elección a partir de ciertas características del libro como objeto. Se trata solamente de cinco niños: dos de JX, uno de JZ y dos de PZ. Todos eligen la enciclopedia y aluden al tamaño del libro como dato privilegiado. Mencionan que es más grande, que tiene más páginas, que su lomo es más grueso, etcétera.

Veamos algunos ejemplos de las verbalizaciones de los niños. Stefanía de Primero Z, señala la enciclopedia:

"Este libro te enseña más porque es más grande." Luego mira el cuento y agrega rechazando: "Este (cuento) es cortito, es un cuento".

Santiago de Primero Z, señala la enciclopedia:

"Porque es más grande", luego señala en el cuento el lomo y comenta: "Este lomo es muy chiquito". Señala el informativo y agrega: "Porque éste tiene más hojas y éste (señala el cuento) menos".

Tanto niños de Jardín X como de Jardín Z hacen alusión al tamaño:

"Porque tiene más y es más grande";

"Porque hay cosas de abejas. Porque es más grande".

Niños de ambos grupos de Jardín justifican focalizando en la cantidad de páginas:

"Tiene más hojas";

"Porque hay más hojas" 
Es probable que estos niños apelen al tamaño o a la cantidad de hojas para justificar su elección porque establecen cierta relación entre el tamaño del soporte y la multiplicidad del material informativo que suele contener una enciclopedia.

\subsubsection{Justificaciones que toman en cuenta ciertos rasgos específicos de los textos literarios ylo de los enciclopédicos}

Los cuarenta niños que utilizaron este tipo de justificación han elegido la enciclopedia. Recordemos que corresponden al $38 \%$ de la muestra total.

Veamos cómo se distribuyen estas respuestas por nivel de escolaridad y tipo de escuelas.

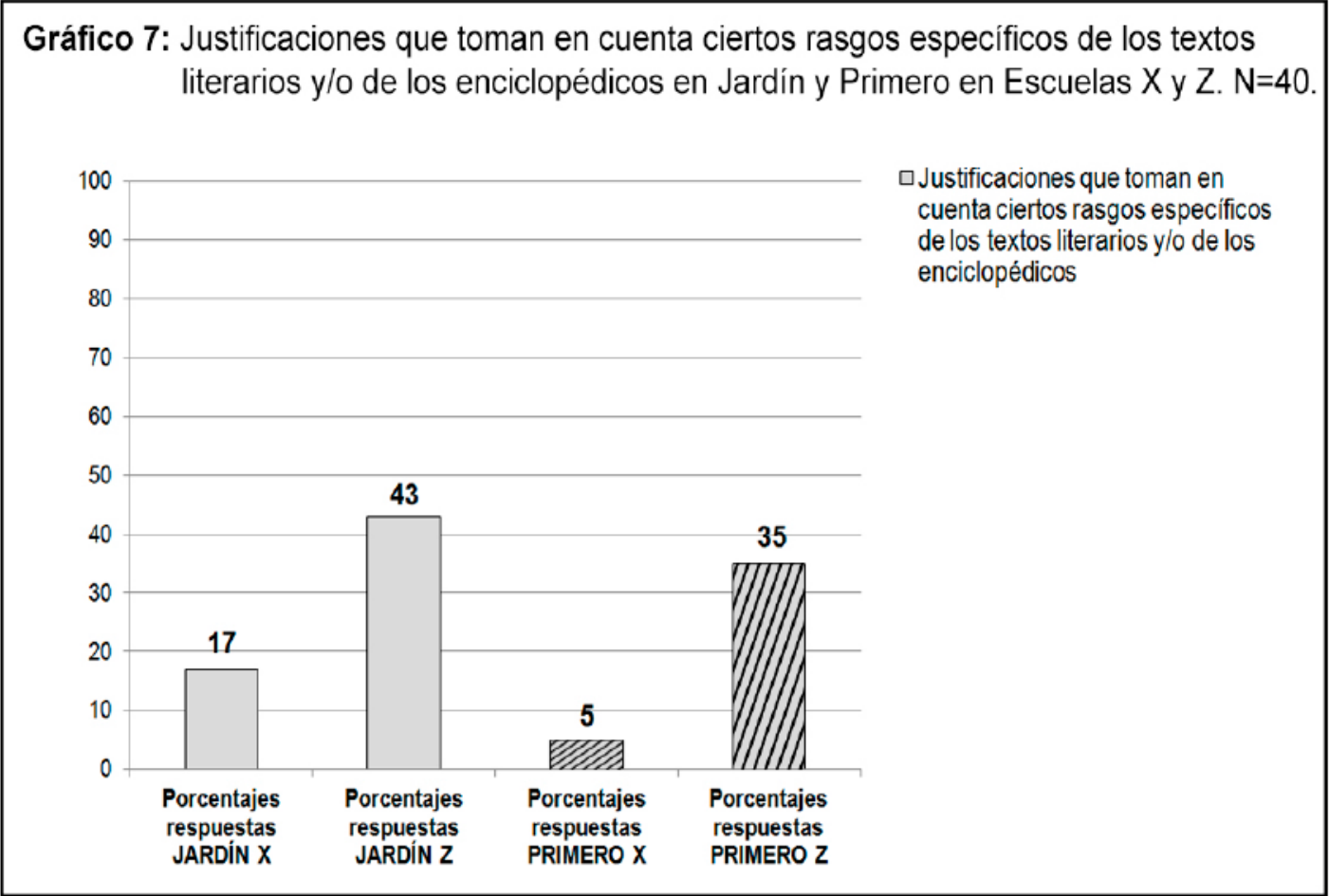

La distribución pone de manifiesto una diferencia significativa entre las escuelas que tienen diferentes contextos de enseñanza: el $88 \%$ por ciento de las respuestas corresponde a las Escuelas Z (43\% a Jardín y $35 \%$ a Primer Grado) y un $22 \%$ a las Escuelas X.

Estas respuestas toman algunos rasgos específicos de los textos enciclopédicos y los cuentos. Los niños explicitan su aproximación a estos rasgos de diferentes maneras. 
Algunas respuestas toman en consideración exclusivamente la función primordial del texto enciclopédico: informar; otras aluden a una oposición entre ciertas características de ambos textos: "es cuento / es de información" y también encontramos justificaciones que expresan la relación entre textos de ficción identificables por ilustraciones características de los cuentos infantiles y textos informativos a partir de fotos o ilustraciones realistas.

Veamos algunos ejemplos:

Aluden a la función primordial del texto enciclopédico: informar.

(Toma la enciclopedia) “Es más natural. Que sabe más cosas" [JX- Daniel]

(Toma la enciclopedia) "Porque acá dice. Este es para aprender ovejas. Ovejas se parece a abejas..." [PZ-Facundo]

(Toma la enciclopedia) "A mí me parece que éste tiene más información. Acá dice todo lo de las abejas. Que pican, que (...) comen miel (...) [PZ-Yamila]

(Toma la enciclopedia) "Porque en este enseña más cómo son los animales. Porque acá te muestra el hueso, cómo es el nombre porque cada un bicho tiene un sobrenombre". [PXAylen]

(Toma la enciclopedia) "Para que aprendas más, este tenés que usar". [JX-Carolina]

(Rechaza el cuento) "Es un cuento y en los cuentos no te explica". [JX- Candelaria]

Aluden a una oposición entre características de ambos textos.

- "Es cuento / es de información":

(Toma el cuento) "Porque es un cuento. (La enciclopedia) Este me sirve porque es de información". [JZ- Marcos]

(Señala el cuento) "Este es un cuento de las abejas (lo rechaza) y este (la enciclopedia) da información". [JZ- Lara]

(Señala la enciclopedia) "Hay muchos insectos (Señala el cuento). Este es un cuento y (Señala la enciclopedia) esto es de informaciones". [JZ- Juan Manuel] 
(Señalando la enciclopedia) "Información de abejas y un cuento" (Señalando el cuento). [JZCiro]

(Señala el informativo) "Es un libro de información de los insectos; este libro (Señala el cuento) de cuentos no sirve porque no informa bien sobre las abejas" [PZ-Carolina]

(Toma el cuento) "En este podés leer que es un cuento, una historia, en el otro no". (Alude a la enciclopedia). [PZ-Tomás]

(Señala cuento) "Parece un libro de leer (Señala la enciclopedia). Es de informaciones yo con la seño hablo de informaciones. ¿Que querés buscar vos, informaciones?”. [JZ-Evangelina ]

(Señala la enciclopedia) "Para información este. Porque con el otro aprendes pero es de cuentos" (Alude al cuento). [PZ-Camila]

- Identifican "cuento / no cuento" con "verdad / falsedad":

Jenifer de PZ, señala la enciclopedia: "Este es de verdad y este es de juguete (Señala el cuento) porque tiene dibujos y palabras chiquitas".

Luisina de PX: "Porque tiene una abeja 'de en serio', este (el cuento) tiene una abeja de mentira. Este (cuento) sirve para ver".

- Vinculan "cuento / no cuento" con si es "para niños o para grandes":

Micaela de JZ señala la enciclopedia: "Porque estos son de grandes y este de dibujitos (Señala el cuento)".

Identifican textos de ficción por ilustraciones características de los cuentos infantiles y textos informativos a partir de fotos o ilustraciones.

"Éste tiene dibujitos pintados como traen los cuentos" , comenta Belén, de Jardín Z, cuando rechaza el cuento. 
Jeremías, de JX, elige la enciclopedia porque en la tapa "tiene bichos de verdad". Nazareno, de primero Z: "Este es un libro de cuentos, tiene colores y este (señala la enciclopedia) es de color blanco porque es de informaciones". Y luego agrega: "Estuvimos viendo un libro de información de mariposas con la seño y ella me dijo que cuando los títulos estaban en el medio (hace ademán de grande) era porque era un libro informativo".

Los niños que esgrimen justificaciones que toman en cuenta ciertos rasgos de los textos literarios y/o enciclopédicos manifiestan un conocimiento que suele provenir de haber participado en prácticas de lectura con enciclopedias y cuentos. Es interesante mencionar que estos alumnos parecen tomar en cuenta ciertos rasgos específicos vinculados con las funciones y tramas predominantes en ambos textos que dos autoras -A.M. Kaufman y M.E. Rodriguez- han cruzado para clasificar los textos de circulación social: en el texto enciclopédico se privilegian la función informativa y la trama descriptiva y/o explicativa; en el cuento la función es, lógicamente, literaria y la trama, predominantemente, narrativa ${ }^{3}$.

\footnotetext{
${ }^{3}$ Ana María Kaufman, A.M. y Rodríguez, M.E. (1993) La escuela y los textos. Santillana. En este texto se propone una clasificación en virtud del cruce de funciones (informativa, literaria, apelativa y expresiva) y tramas (narrativa, descriptiva, conversacional y argumentativa).
} 


\subsection{Re-Capitulando}

Si se analizan los datos vinculados con las justificaciones de los niños, podríamos llegar a las siguientes conclusiones provisorias.

Las respuestas que privilegian exclusivamente la imagen como justificación no garantizan arribar a la elección pertinente.

Distinto es el caso cuando se ponen en juego otros conocimientos sobre los libros. Algunas respuestas ponen de manifiesto que los niños reconocen la función predominante de los textos ("para informar", "para contar", etcétera), los destinatarios a quienes en general van dirigidos ("para chicos", "para grandes"), ciertos aspectos relacionados con la ficción / no ficción ("es de verdad", "no es de verdad"), etcétera.

Estas justificaciones, a diferencia de las que solo apelan a la imagen, tienen más peso en la elección del libro adecuado, porque suponen mayor conocimiento sobre los usos y las características esenciales de los diferentes textos.

Todos los niños de la muestra pertenecen a la misma población sociocultural. La variable que los diferencia es asistir a instituciones escolares que desarrollan diferentes prácticas de enseñanza. Como se ha observado, los niños que realizan mayor cantidad y variedad de justificaciones de este tipo asisten a las instituciones $Z$.

Consideramos que estos alumnos, tanto en Jardín como en Primer Grado, han tenido más posibilidades de interacción con diversos libros de diferente género en función de las prácticas de enseñanza de las que participaron. De hecho, solo en las verbalizaciones de los niños de estas escuelas aparecen evocadas escenas de aula en las que tuvieron acceso a libros similares con sus maestras. 


\section{CAPÍTULO IV \\ LOCALIZAR INFORMACIÓN ESPECÍFICA \\ EN UNA ENCICLOPEDIA}

\section{Introducción}

Con esta tarea nos propusimos indagar qué procedimientos ponen en juego los pequeños para localizar una información específica en un texto informativo cuando la situación demanda un análisis cuidadoso de indicadores gráficos y textuales. También es relevante advertir si los niños sostienen su elección o la modifican en función del contraejemplo que propone el investigador.

Al igual que en la tarea analizada en el Capítulo III, nos interesa comparar si existen diferencias entre los grupos que han participado en prácticas de enseñanza disímiles (Escuelas X y Escuelas $Z^{1}$ ), como así también cuáles son las respuestas de los niños que se encuentran en distintos niveles de escolaridad (salas de 5 años de Jardín y Primer Grado).

\footnotetext{
${ }^{1}$ Como explicamos en el Capítulo II las Escuelas X se caracterizan por prácticas de enseñanza usual y las Escuelas Z por prácticas de enseñanza "constructivistas".
} 


\subsection{Descripción de la situación experimental}

La tarea planteada consistía en localizar específicamente en qué páginas de la enciclopedia se encontraba información sobre las abejas. Procuramos investigar cómo hacían los niños para encontrarla y cómo justificaban su elección.

El libro que utilizamos contiene -entre otros- dos insectos parecidos en su fisonomía: las abejas y las avispas. El hecho de que la escritura de los nombres sea similar constituye un problema añadido para los niños: las palabras comparten la letra inicial y las dos finales, las segundas letras de cada palabra $(\mathrm{V} \circ \mathrm{B})$-si bien diferentes desde el punto de vista gráfico- poseen identidad fónica y la cantidad de letras en ambas palabras es muy pareja (seis y siete).

Tal como se aclara en el Capítulo II, que tomamos la decisión de preguntar "dónde dice sobre las abejas" y no "dónde dice 'abejas" porque consideramos que el primer enunciado es más amplio ya que incluye diversas informaciones, a diferencia del segundo que restringe la búsqueda a la localización de una palabra. Se les brindó el tiempo necesario para que explorasen y buscasen la información solicitada. El investigador planteó, además, contraejemplos para facilitar la reflexión de los niños acerca de la elección realizada y poder así verificar la estabilidad de sus respuestas, comprobando si cambiaban de parecer o sostenían lo escogido.

Al comienzo de la entrevista, el investigador mostraba el libro cerrado en la mesa y le decía al niño:

"Acá hay información sobre las abejas, ¿cómo podemos hacer para encontrarla?"

Luego observaba y registraba las distintas decisiones infantiles en el proceso de exploración del material, todos sus señalamientos y verbalizaciones. En el caso de que los niños no justificaran su elección, el investigador se lo solicitaba:

"¿Cómo te diste cuenta de que aquí (donde había señalado el niño) dice sobre las abejas?

Mostrame con el dedo dónde te fijaste para saber si dice algo sobre las abejas".

Si el niño remitía solo a las imágenes, se le preguntaba:

¿¿Hay otro lugar en que puedas fijarte aparte de los dibujos?"

Si el niño no se remitía a lo escrito la pregunta era más específica:

"Si nos tuviéramos que fijar donde está escrito, ¿en qué parte te fijarías para saber rápido si dice algo sobre las abejas?" 
A continuación de su respuesta se brindaba un contraejemplo que consideraba diferentes opciones en función de lo que el niño hubiera elegido (abejas, avispas u otro insecto).

- $\quad$ Si el niño señalaba la imagen de las abejas, se le mostraba la página de las avispas comentando: "Otro nene me dijo que podía ser en ésta" (avispas).

- $\quad$ Si el niño señalaba la imagen de las avispas, se le mostraba la página de las abejas comentando: "Otro nene me dijo que podía ser en ésta (abejas) acá hay un dibujo parecido..."

- Si el niño tomaba en cuenta algunas letras de ABEJAS², se le mostraba AVISPAS y se le decía que allí también había algunas letras de "abejas".

- $\quad$ Si el niño tomaba en cuenta algunas letras de AVISPAS, se le mostraba ABEJAS, y se le decía que allí también había algunas letras de "avispas".

- Si el niño decía "en las dos páginas", se le decía: "solo una dice sobre las abejas" y se le preguntaba cuál.

En todos los casos se les solicitaba justificación de sus respuestas.

\footnotetext{
${ }^{2}$ En adelante, ABEJAS y AVISPAS en esta tipografía hace referencia a los títulos correspondientes.
} 


\subsection{Descripción del libro utilizado}

La enciclopedia seleccionada ${ }^{3}$-como se ha mencionado en capítulos anteriores- es un material de difusión sobre insectos destinado a un público diverso, no específicamente a niños pequeños. E material respeta las características del género en tanto objeto material, organización textual y paratextual a lo largo de sus páginas.

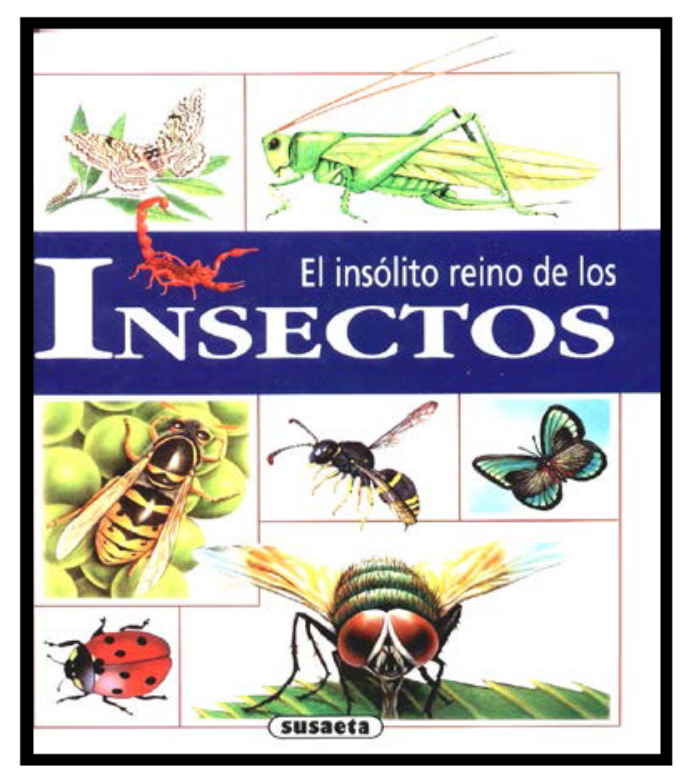

Es un libro de $29 \mathrm{~cm}$. de largo por $22 \mathrm{~cm}$. de ancho, de tapas duras. Las imágenes de la tapa ilustran ocho insectos, entre los cuales están las abejas y las avispas, según rasgos de edición canónicos para este tipo de materiales: un título destacado e ilustraciones realistas en color.

En su interior, el libro brinda información sobre doce insectos y no respeta un orden alfabético u otro orden particular que posibilite cierta anticipación al lector. La secuencia es la siguiente: hormigas, chinches, cucarachas, avispas, escorpiones ${ }^{4}$, cigarras, mantis, langostas, moscas, abejas, mariquitas, mariposas.

La información referente a cada insecto ocupa una doble página, organizada a partir de un título en letra imprenta mayúscula (de cuerpo grande y con letras marcadamente separadas) y varios subtítulos en imprenta mayúscula y minúscula, algunos de los cuales forman parte de recuadros específicos. Hay más de una ilustración realista de cada insecto.

\footnotetext{
${ }^{3}$ Enciclopedia infantil El insólito reino de los insectos. Susaeta Ediciones, Madrid, España (1999).

${ }^{4}$ De acuerdo con la clasificación científica, los escorpiones no son insectos. Si bien pertenecen, junto a los insectos, a un grupo más amplio -el de los artrópodos-, los escorpiones son en realidad arácnidos. A pesar de este error, frecuente en libros divulgación, hemos decidido incorporar el material por su adecuación a los propósitos de nuestra investigación.
} 


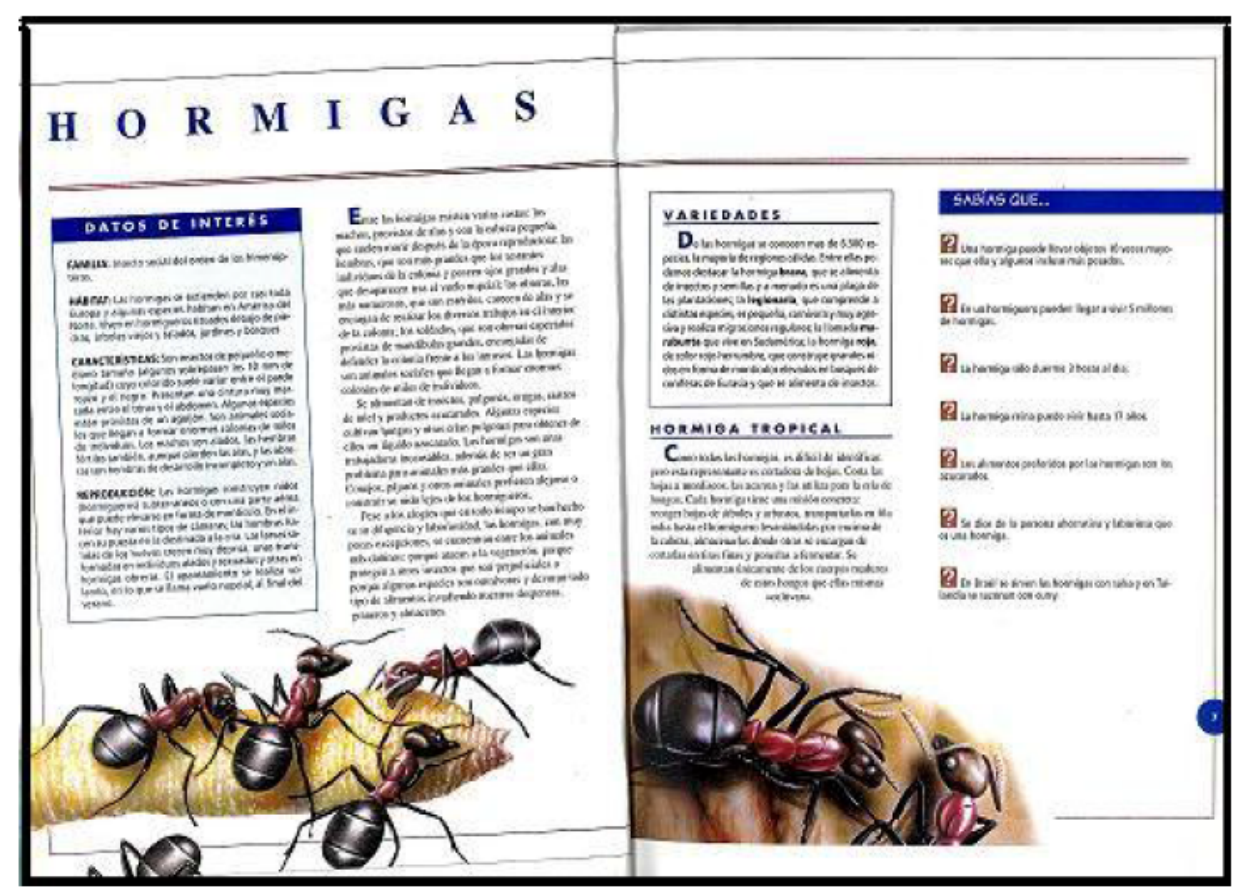

La tipografía del texto principal es imprenta mayúscula y minúscula. El título principal, los títulos secundarios o subtítulos y el texto principal presentan tamaños diferentes.

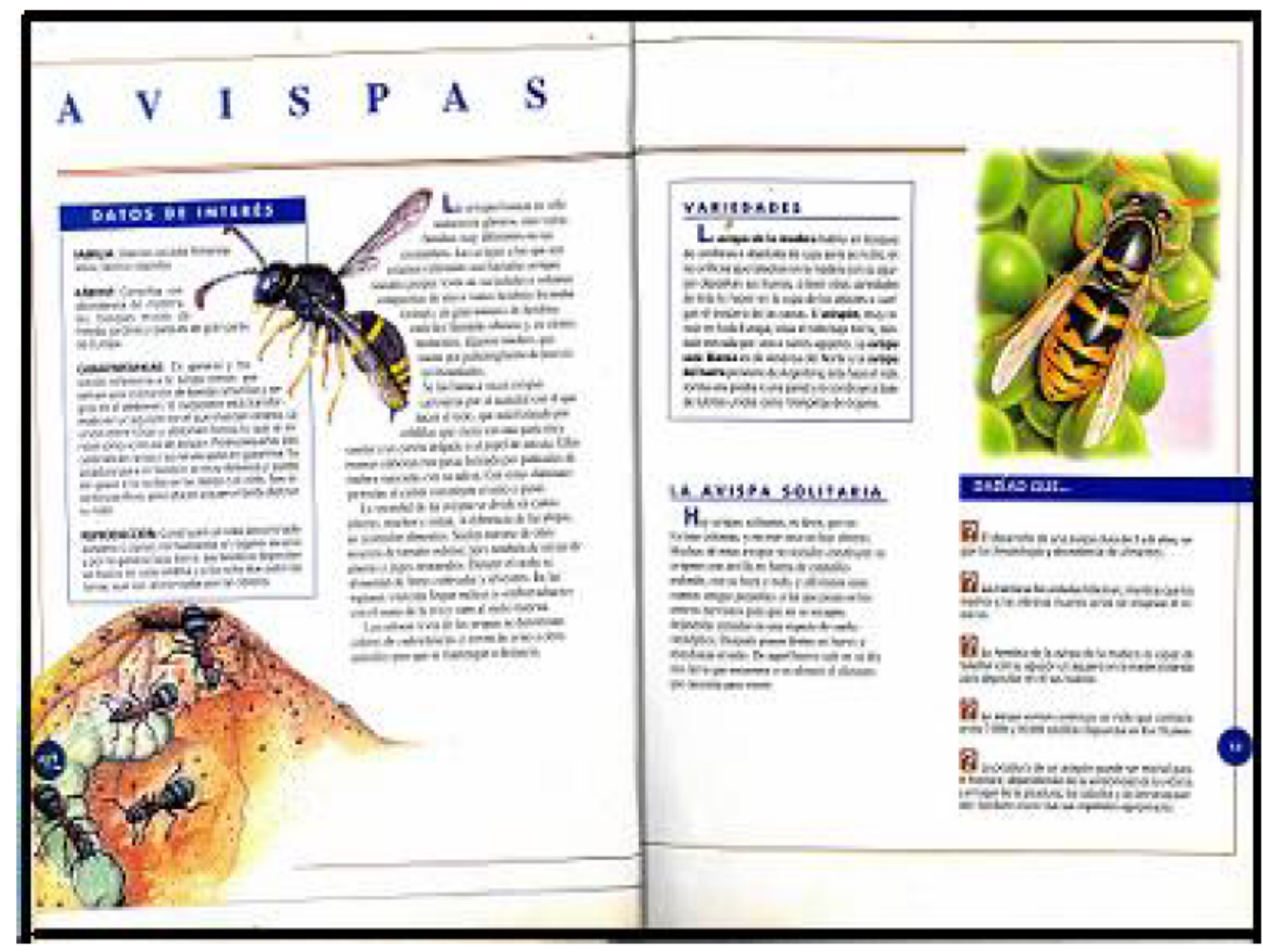

Las páginas que se refieren a las avispas aparecen antes en el libro (páginas 12-13) que las de las abejas (páginas 24-25). Las cuatro páginas presentan ilustraciones realistas muy similares que 
pueden prestarse a confusión, lo cual favorece la posibilidad de intervención del investigador, como explicitaremos más adelante.

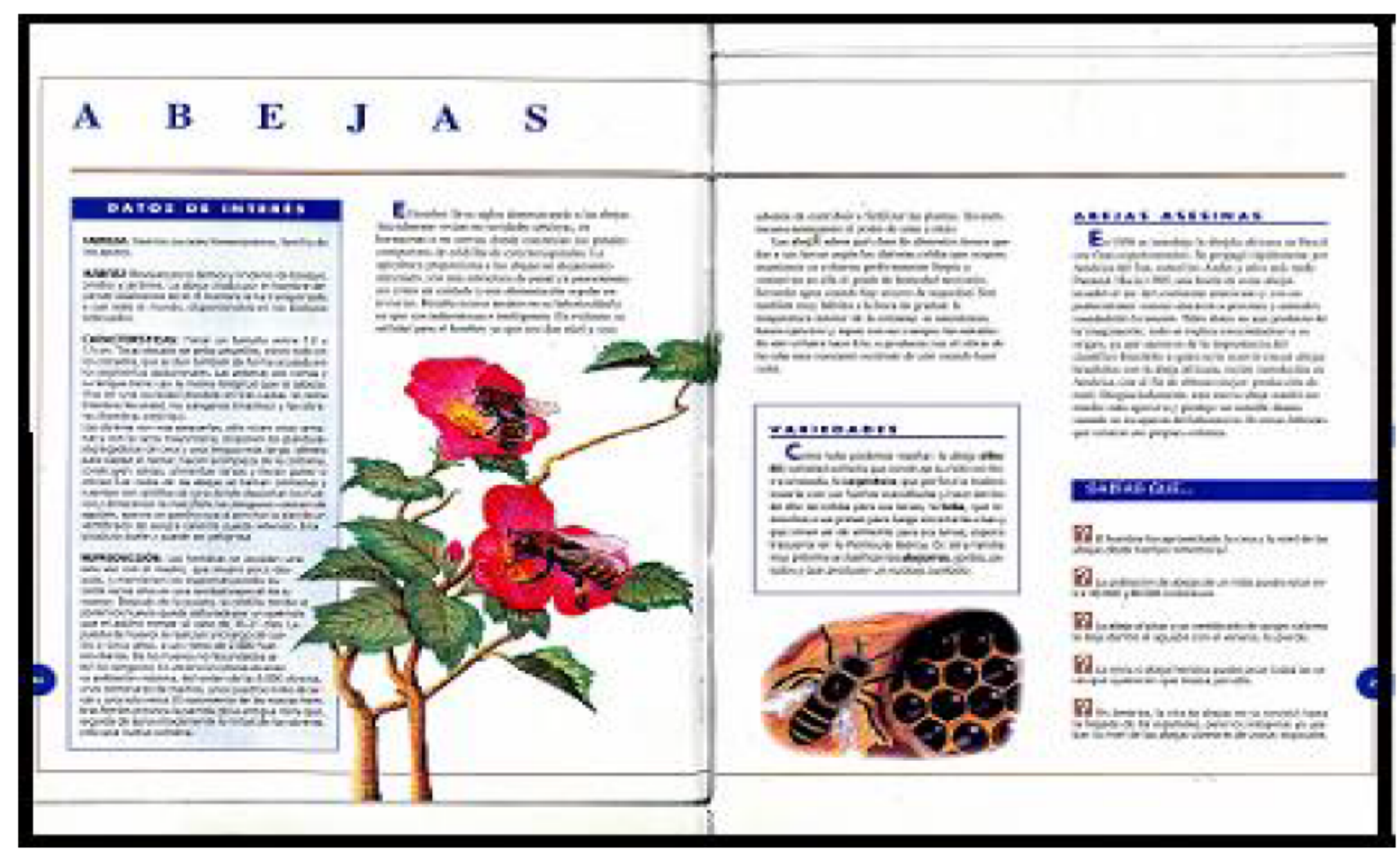

En el Anexo Il se incluye una copia completa de la enciclopedia.

\subsection{Análisis de las respuestas de los niños para localizar "dónde dice sobre las abejas"}

Como mencionábamos anteriormente los niños realizaban una elección inicial frente a la pregunta del investigador "dónde dice sobre las abejas". Hemos analizado cómo se distribuyen esas primeras elecciones en el total de los niños estudiados. Luego, observamos los procedimientos puestos en juego y por último describimos y analizamos los diferentes recorridos que transitan los niños a partir del contraejemplo enunciado por el investigador. Intentamos comprender de qué manera sostienen o transforman la respuesta inicial a partir de esa intervención.

En esta tarea, los niños disponían el libro en la mesa y frente a la solicitud del Investigador realizaban su elección inicial. Advertimos tres tipos de respuestas: 57 niños eligieron efectivamente la página de las "abejas", 60 eligieron la página de las "avispas" y sólo cinco niños 
de Jardín (3 de $Z$ y 2 de $X$ ) no lograron decidirse por ninguna página y sus respuestas fueron ambiguas, por esta razón, no serán incluidas en el análisis. Por esta razón, en este Capítulo, el total de la población se restringe a 117 sujetos.

\subsubsection{Comparación de las respuestas de los niños en la elección inicial y final}

En la elección inicial, la población se divide prácticamente por la mitad entre los que seleccionan la página de las abejas y los que eligen la de las avispas (Gráfico 1).

Gráfico 1: Porcentaje de respuestas para la elección inicial. N=117

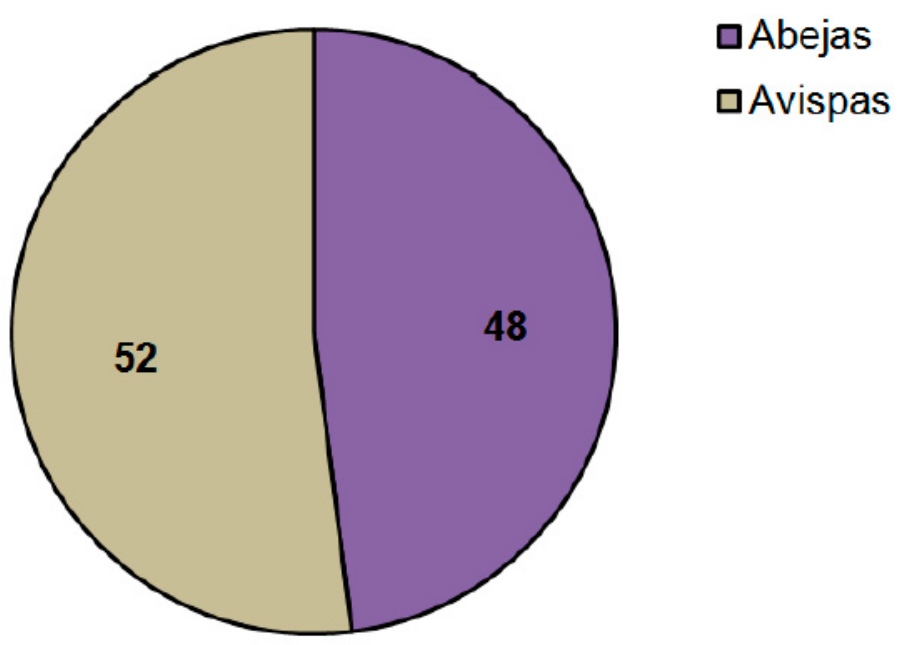

El $52 \%$ correspondiente a la elección de la página de las avispas incluye 60 respuestas, mientras que el $48 \%$ restante responde a 57 respuestas. 
Nos pareció importante investigar a qué escuelas pertenecían los niños que daban estas respuestas. En el Gráfico 2 desagregamos ambos tipos de respuesta.

Gráfico 2: Distribución de las respuestas iniciales en función del tipo de escuela ( $X$ y $Z$ ). $N=60$ (AV); N=57 (AB).

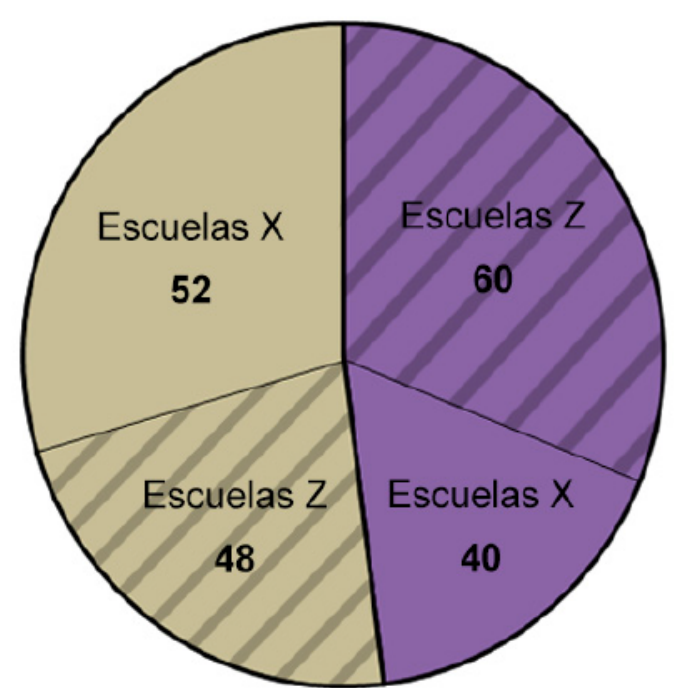

口Abejas

$\square$ Avispas

口Escuelas X $(\mathrm{J}+\mathrm{P})$

曰Escuelas $Z(\mathrm{~J}+\mathrm{P})$

Veamos en primer término las respuestas inadecuadas. Tal como se advierte en el Gráfico, los porcentajes entre ambos tipos de escuela son muy parejos ( $X=52 \%$ y $Z=48 \%$ ). En cambio, los niños que eligen la página de las abejas pertenecen mayoritariamente a las Escuelas $Z$ ( $X=40$ y $Z=60)$. Consideramos de interés verificar si la elección inicial se mantiene después de las intervenciones del investigador, consistentes en pedir fundamentaciones y brindar contraejemplos para corroborar la estabilidad de las respuestas. 
Detengámonos en cómo se distribuyen las respuestas en la elección final.

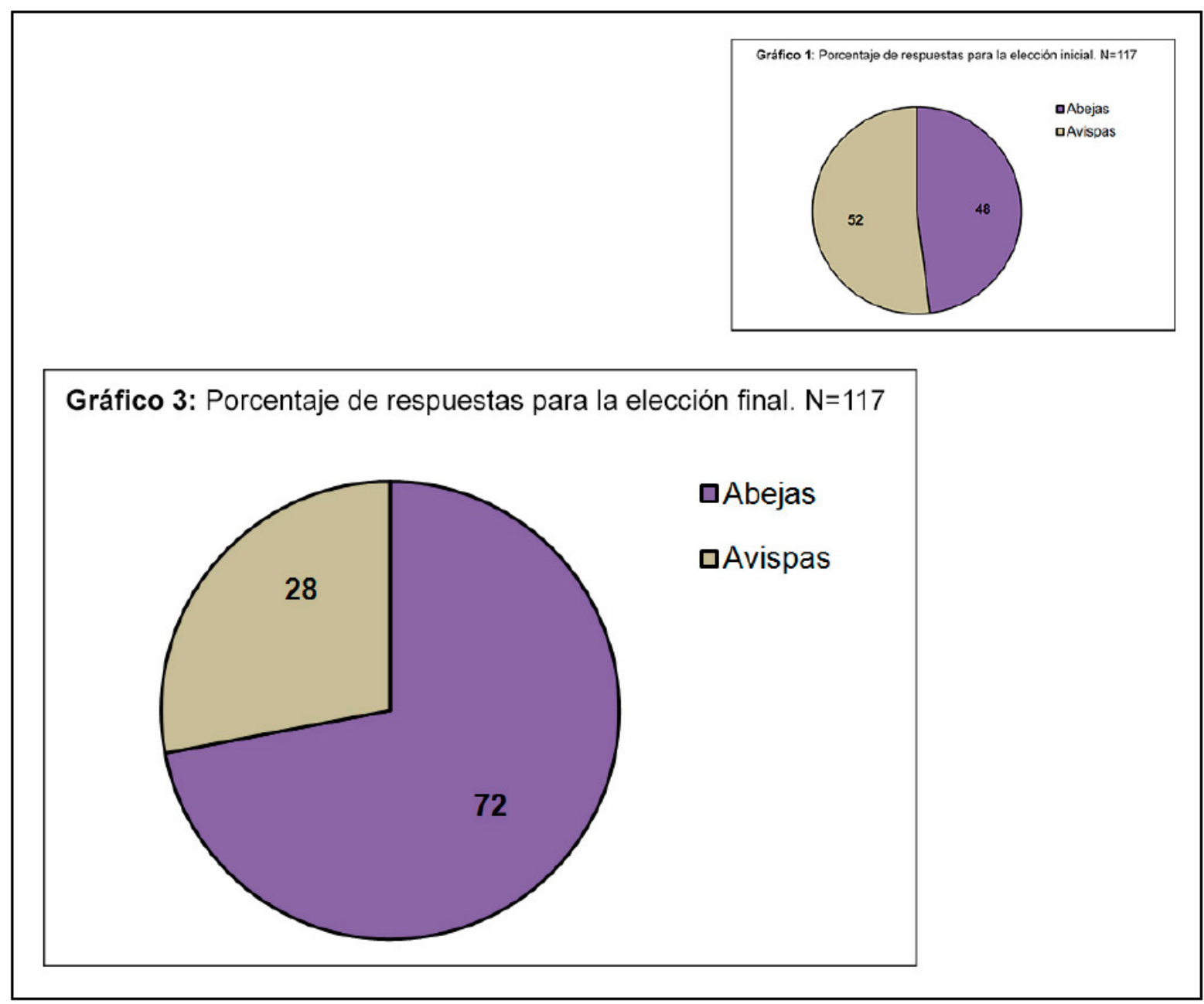

Podemos advertir que hubo un cambio importante. El $52 \%$ de niños que habían seleccionado inicialmente la página incorrecta, se redujo a un $28 \%$ después de las intervenciones del investigador. De este modo, podemos advertir que el $72 \%$ restante culminó su búsqueda en la página correcta.

Estos porcentajes, también, se desagregaron por tipo de escuelas advertimos cambios interesantes. 
En cuanto a la pertenencia institucional de los niños, de las respuestas inadecuadas en la selección final (avispas), un 67\% corresponde a alumnos de Escuelas X y el 33\% restante asiste a Escuelas Z.

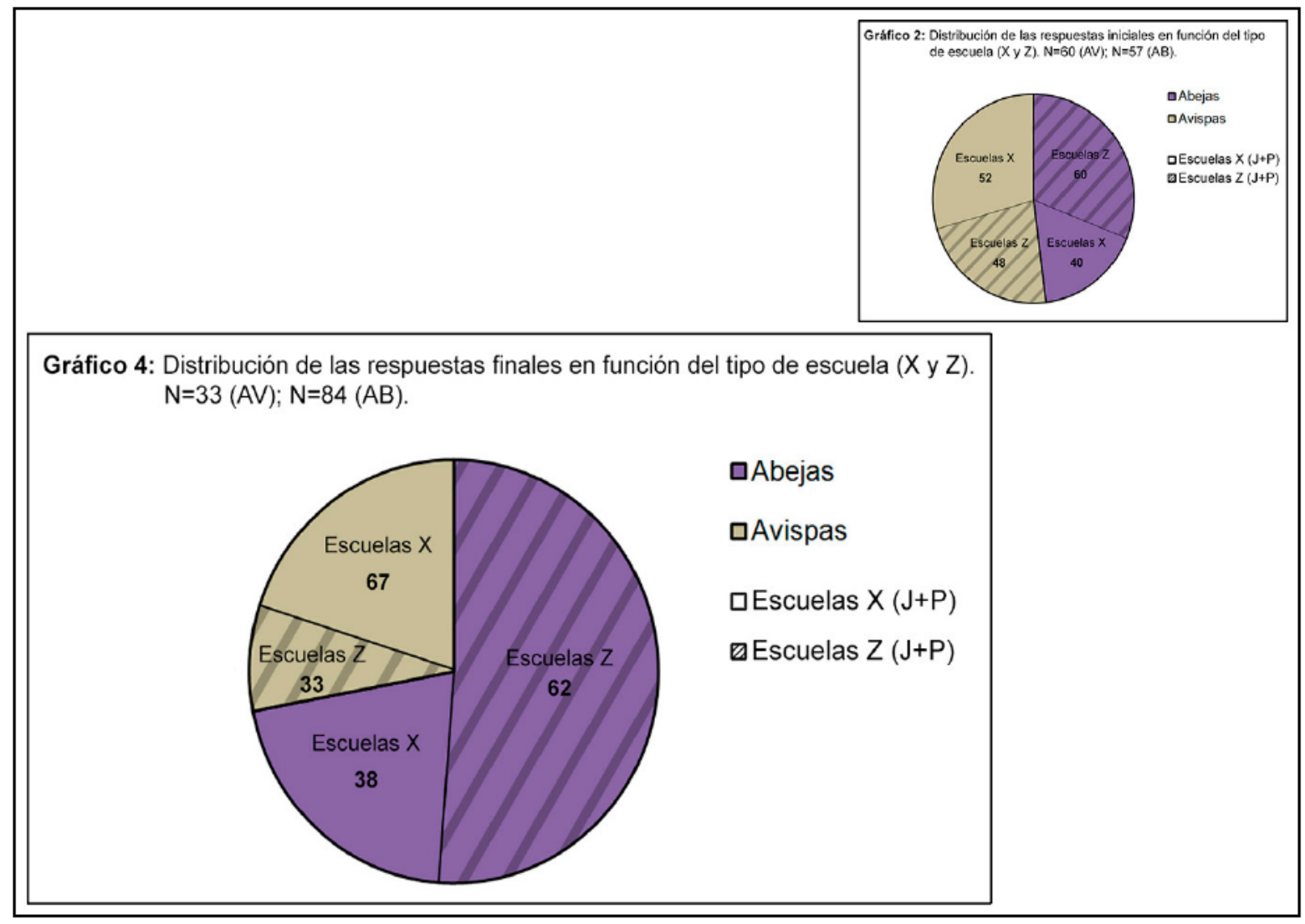

En cuanto a los que responden adecuadamente después del contraejemplo, el $38 \%$ corresponde a las Escuelas X mientras que el $62 \%$ restante fueron respuestas de niños de las Escuelas $Z$.

En el apartado siguiente analizaremos las respuestas de los niños a partir de la intervención y los contraejemplos del investigador. 


\subsection{Análisis de las respuestas de los niños a partir del contraejemplo del investigador}

En la tarea propuesta los niños seleccionaban inicialmente la página donde creían que "decía sobre abejas" y se les pedía que justificaran la elección realizada. A partir de esa localización inicial, el investigador proponía un contraejemplo ("Otro nene me dijo que podía ser en ésta", señalando una página diferente a la elegida).

Según la elección inicial realizada y la página final a la que arribaron como respuesta final, pudimos identificar varios recorridos que agrupamos en cuatro categorías de análisis que nos permitieron estudiar las relaciones entre las primeras decisiones de los niños y sus reacciones a los contraejemplos. Es interesante analizar el efecto de estos últimos tanto en niños cuya elección inicial es la página de abejas como en los que escogen la de las abejas.

\subsubsection{Caracterización de las respuestas entre la localización inicial y la posterior al contraejemplo del investigador}

Hemos encontrado cuatro recorridos posibles: los que ingresan por la página de las abejas y culminan en ella; los que ingresan por esa página y cambian de opinión; los que ingresan por la página de las avispas y culminan en ella y los que ingresan por esa página y cambian de opinión.

Para describir los recorridos usaremos los siguientes códigos:

- la página de abejas será consignada como AB;

- la de avispas AV;

- la elección correcta - página de abejas- se abreviará con el signo más (+)

- la incorrecta con el signo menos (-).

Podemos sintetizar los recorridos o respuestas de los niños según las siguientes categorías:

- Ingresan inicialmente a la página de abejas y el contraejemplo no los hace cambiar de opinión: AB+. 
- Ingresan por la página de avispas y cambian de opinión ante el contraejemplo señalando página de abejas: AV+.

- Ingresan por la página de abejas y frente al contraejemplo cambian de opinión y eligen otra página: AB-.

- Ingresan por la página de avispas y el contraejemplo no los hace cambiar de opinión: AV-.

Las respuestas que seleccionan inicialmente la página de abejas y concluyen en ella a pesar del contraejemplo $(\mathrm{AB}+)$ corresponden tanto a niños que en el primer momento de la tarea toman en consideración las escrituras -hojearon el libro y consideran los títulos principales, ingresan por el ÍNDICE o complementaron la información de las imágenes con las escrituras- como a otros que utilizan la imagen como único indicador. Cabe señalar que, cualquiera sea el procedimiento, se detienen inicialmente en la página de abejas y anclan en ella, pasando por alto la página de avispas, que en la enciclopedia antecede a la de las abejas. Sostienen su idea inicial, aún cuando el investigador les presenta otra opción. El contraejemplo es refutado por los niños, quienes insisten en justificar su elección, tal como puede observarse en el siguiente ejemplo:

Investigador: ¿Dónde podemos encontrar en este libro información para saber de las abejas? (Alumno hojea y se detiene en la página de las abejas): En los dibujos. Por ahí tiene una flor y le chupa toda la miel que tiene. (Sigue mirando la página de abejas, se queda en silencio unos segundos)

I: ¿Vos decís que ahí es de abejas, por los dibujos? (Página de las abejas)

A: Sí.

I: Además de mirar los dibujos, ¿cómo podemos estar seguros que es la página de las abejas?

A: Lo tenés que leer todo.

I: ¿Cómo haces?

A: Acá. "Abejas". (Señala ABEJAS).

I: ¿Qué es eso?

A: Es el título.

I: Un nene me dijo que "abejas" dice en estas (muestra páginas 12-13 sobre las avispas). ¿Qué opinás?

A: Que no.

I: ¿Cómo te das cuenta? 
A: Por el dibujo.

I: Y vos antes dijiste que por los dibujos pero también porque "lo tenés que leer todo".

A (se queda unos instantes mirando la página): Acá (señala AVISPAS). Ahí dice "a- vis..." No, esta (refiriéndose a la página) es de las avispas.

I: ¿Y dónde dirá sobre las abejas?

A (Hojea y llega a las páginas 24-25): En estas. (Señala título ABEJAS y las ilustraciones de las páginas) [PZ Silvio]

Las respuestas de los niños que ingresan por avispas y cambian de opinión $(A V+)$ incluyen, al igual que las del grupo anterior, los procedimientos ya mencionados.

Estos niños arriban, en primera instancia, a la página de avispas y concluyen en la de abejas. Este cambio de idea ocurre por una búsqueda personal o a partir del contraejemplo que introduce el investigador. Todos ellos brindan diferentes justificaciones para llevar adelante ese cambio de parecer. Más adelante nos centraremos en este dato.

Mariana, de Primero $Z$, toma el libro, lo hojea y arriba en primer lugar a la página de avispas focalizando en la imagen:

Alumno: Es ésta porque las abejas tienen amarillo, tienen alas, tienen ojos, tienen antenitas (Describe la ilustración de las avispas de la página 13.)

Investigador: (Señala las páginas 24 y 25 correspondientes a las abejas) Otro nene se fijó acá y me dijo que hay ilustraciones como las que decís.

A: (Hace silencio, se queda pensativa unos segundos.)

I: ¿Cómo podés estar segura de cuál dirá sobre las abejas?

A (En la página de abejas): Está todo escrito acá (señala globalmente varios textos).

I: ¿Cómo sabemos si es de abejas o no?

A: Podemos mirar acá (señala el recuadro "variedades" de la página 25. Lee el contenido del recuadro con voz) "co-mo-ta-les...." (Al llegar a la palabra abejas se detiene, tapa con sus manos todo menos la palabra abejas): Acá dice abejas. Ésta es de las abejas. (Refiriéndose a las páginas 24 y 25)

Las respuestas que ingresan por abejas y frente al contraejemplo cambian de opinión y van a otra página (AB-) en general han hojeado, han llegado a la página de las abejas $\mathrm{y}$, frente al contraejemplo, cambian de opinión, tal como le ocurre a Alan, de Jardín X. 
Alumno: (Hojea) Acá (ilustración pág. abejas) Porque las abejas sacan miel de adentro de esas flores. Otras flores no tienen miel.

Investigador: ¿En qué otra cosa te fijarías?

A: Acá (señala ilustración de panal). Porque acá tienen sus casas.

I: Pero mirá en esta página (avispas). Un nene me dijo que acá podría decir sobre las abejas.

A: Acá hay una abeja mirando para allá (señalando ilustración de avispas).

I: ¿Entonces en qué hoja tendrías que fijarte si te dijera que en un solo lugar dice?

A: Acá (ilustración de avispas) porque hay más abejas.

I: Además de los dibujos, ¿podrías fijarte en otro lugar?

A: No.

Los niños que eligen inicialmente avispas y el contraejemplo no los hace cambiar de opinión (AV-) en general han hojeado el libro y al encontrar primero la página de las avispas se detienen en ella y persisten en su elección a pesar del contraejemplo. Una alumna de Primer Grado, Micaela de PX, constituye un ejemplo de esta categoría.

Alumna: (Hojea se detiene en la página de avispas): Acá.

Investigador: ¿Cómo te das cuenta?

A: Es porque yo lo busqué y lo encontré.

I: ¿Cómo te das cuenta de que acá hay información sobre abejas?

A: Hay muchas abejas. Acá hay una grande y acá otra (señala ilustración de la página 12 y de la 13).

I: Otro nene me dijo que también acá hay abejas (Muestra página 24 y 25)

A: Sí, eso sí puede ser.

I: Entonces, ¿dónde dirá sobre abejas, acá o acá? (señalando páginas 12-13 y 24-25)

A: Acá (señala ilustraciones página 12). Porque acá está la casa y acá está afuera.

I: Aparte de los dibujos, ¿en qué otro lugar nos podríamos fijar para saber más sobre las abejas?

(A no responde.)

I: Si nos tuviéramos que fijar donde está escrito para saber rápido, ¿dónde te fijarías?

A: No sé, porque no está la 'a' sola. Tiene que estar la ' $a$ '.

I: ¿La 'a'?

A: No, no sé.

I: ¿Dónde dice "abejas"?

A: Ésta (señala la página 12) porque pensando... Porque yo me fijo bien. 
Los cuatro recorridos se distribuyen de manera particular en el total de niños entrevistados. Los analizamos en el siguiente apartado.

\subsubsection{Distribución de los diferentes recorridos transitados por los niños}

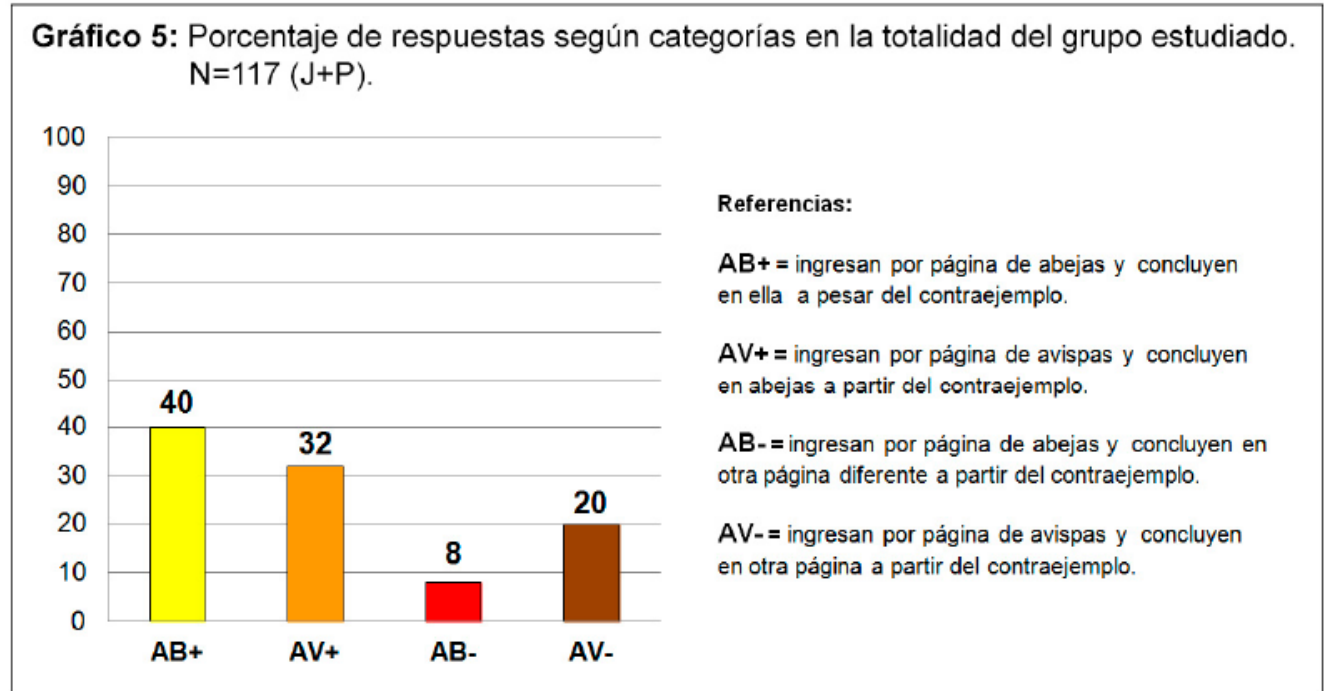

Las dos primeras columnas $(40 \%+32 \%=72 \%)$ corresponden a 84 respuestas que concluyen en la página adecuada de abejas, y se trata de niños que han ingresado a la tarea por avispas (37 respuestas) o por abejas (47 respuestas).

La tercera columna $(8 \%)$ presenta el porcentaje de respuestas de quienes ingresan por la página adecuada -abejas- pero cambian de opinión: son sólo 10 alumnos.

Las 23 respuestas de la cuarta columna (20\%) pertenecen a quienes ingresan por avispas y sostienen su opinión a pesar del contraejemplo del investigador.

Los resultados numéricos expuestos ponen en evidencia que la mayoría de los niños puede localizar la página de la enciclopedia que contiene la información solicitada. Solo el $28 \%$ de los niños no llegan a la página adecuada al finalizar la entrevista.

Este dato es de sumo interés, considerando que no se trata de un material didáctico propio de la tradición escolar controlado en cantidad de grafías y extensión, sino de un material de circulación social al que los niños pueden tener acceso desde muy pequeños.

Si bien el resultado numérico nos permite destacar la posibilidad infantil de arribar a respuestas correctas, nos interesa analizar de manera más pormenorizada los distintos recorridos, correctos o 
incorrectos, a fin de describir e interpretar el sentido de las respuestas y su presencia en Jardín y Primer Grado en los grupos X y Z.

\subsubsection{Distribución de los recorridos según nivel de escolaridad}

En el Gráfico 5 podemos advertir cómo se distribuyen las categorías según el nivel de escolaridad: Jardín y Primer Grado.

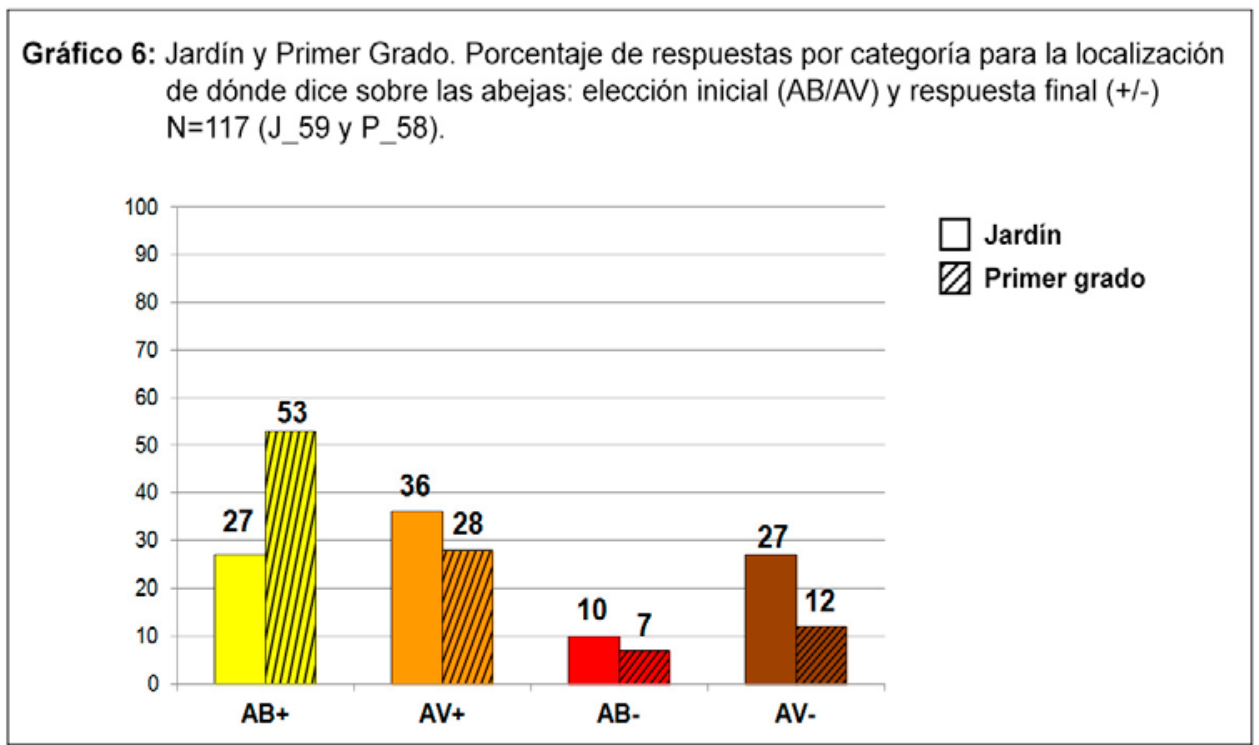

Podemos observar que hay respuestas tanto de Jardín como de Primer Grado en todas las categorías.

El primer par de columnas corresponde al porcentaje de respuestas que arribaron, desde la elección inicial, a la página adecuada. Es evidente que en Primer Grado lo logran en mayor medida.

El segundo par de columnas muestra el porcentaje de las respuestas que ingresaron inicialmente por la página de las avispas y que han culminado satisfactoriamente en la de las abejas; en este caso es mayor el porcentaje en las respuestas de Jardín.

Tomando en consideración los dos primeros pares de columnas, podemos señalar que -como es esperable- es más alto el porcentaje de respuestas que localizan la página de abejas en Primer Grado $(53+28=81 \%)$ que en Jardín $(27 \%+36 \%=63 \%)$.

El tercer par de columnas no muestra mayores diferencias entre los niveles de escolaridad. 
En el último par de columnas, que corresponde a las respuestas que ingresan por la página de avispas y frente al contraejemplo del adulto no logran cambiar de opinión, observamos que es mayor el porcentaje en Jardín.

Otro dato que surge de este análisis cuantitativo, se vincula no ya con los recorridos sino con la elección inicial. En ese caso hay un contraste interesante entre los Jardines y los Primeros Grados. El $63 \%$ de los pequeños de Jardín se detiene en las páginas de las "avispas" como primera elección ( $\mathrm{AV}+=36 \%$ y $\mathrm{AV}-=27 \%$ ). En Primer Grado, ese porcentaje desciende al $40 \%$. Es probable que este dato se relacione con el hecho de que la página de las avispas se encuentra antes en la enciclopedia y al hojear los niños más pequeños tomen indicios algo apresurados sin continuar la búsqueda hasta el contraejemplo dado por el investigador.

\subsubsection{Distribución de los recorridos según el tipo de escuela a la que asisten}

En el Gráfico 6, analizamos los recorridos en función de lo que sucede en los jardines y en los primeros grados. Expondremos, a continuación, en el Gráfico 7, los recorridos de Jardín contemplando el tipo de institución: $X$ y $Z$.

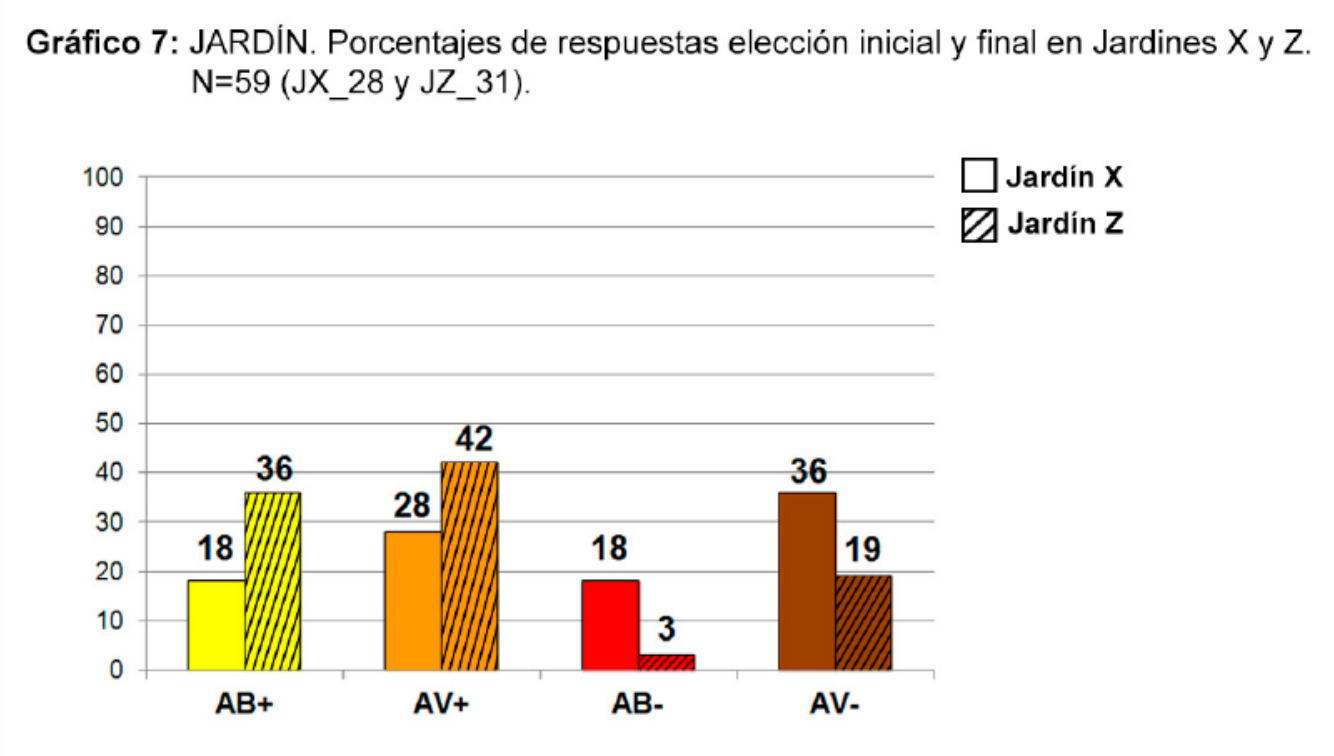

El análisis por tipo de institución aporta resultados de gran interés. En todos los casos, la relación porcentual se presenta a favor de los Jardines $Z$ con respecto a los $X$. 
A partir de los datos consignados en el Gráfico 7, puede advertirse que en los Jardines $Z$ el $78 \%$ llega a la página correcta ( $36 \%$ de $A B+$ y $42 \%$ de $A V+)$. En cambio, en los Jardines $X$, este porcentaje asciende al $46 \%(18 \% A B+Y 28 \% A V+)$. Si consideramos las respuestas que arriban a otras páginas, el $22 \%$ corresponde a los Jardines $Z$ (3\% AB- y $19 \%$ AV-) y un $54 \%$ a los Jardines $\mathrm{X}(18 \%$ AB- y $36 \%$ AV-).

El gráfico 8 refleja los porcentajes correspondientes a Primer Grado de las Escuelas X y Z.

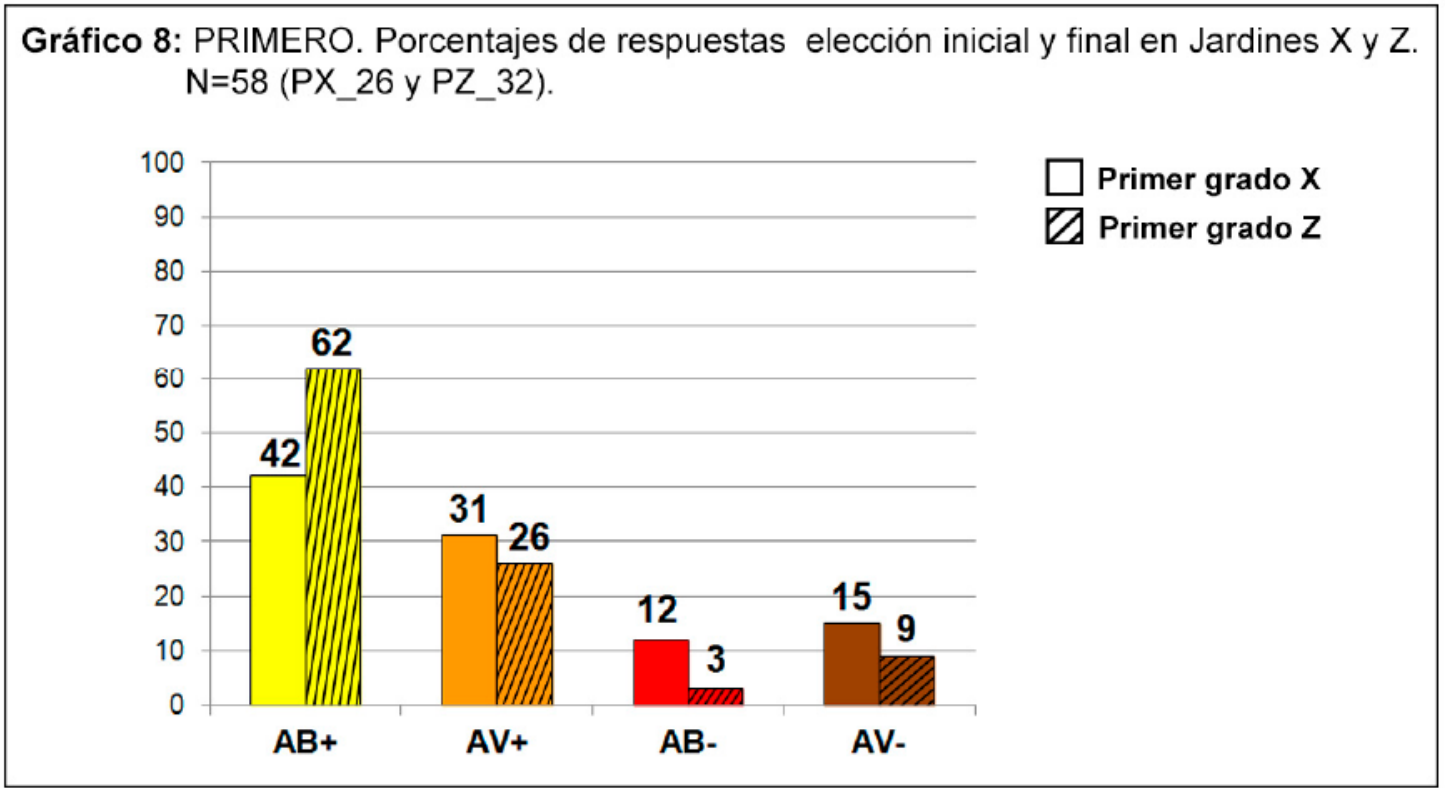

En Primer Grado, el $88 \%$ de las respuestas del grupo $Z$ arriban a la página adecuada $(A B+62 \%$ y $A V+26 \%$ ). En las Escuelas $X$ el porcentaje de este tipo de respuesta suma $73 \%$.

En cuanto a los porcentajes de las respuestas que concluyen en la página incorrecta, en las Escuelas $Z$ alcanza un $12 \%$, mientras que en $X$ asciende a un $27 \%$.

Tanto en Primer Grado como en la sala de 5, los porcentajes de los niños que arriban a la página adecuada son mayores en los grupos $Z$ que en los $X$. 


\subsubsection{Análisis pormenorizado de los recorridos en las Escuelas X y Z}

Hasta aquí hemos puesto de manifiesto que los niños realizan distintos recorridos en su interpretación del material para arribar a una respuesta final y presentamos sus resultados en términos cuantitativos según los grupos de Jardín y Primer Grado en instituciones X y $Z$.

Es necesario analizar qué ocurre al interior de cada categoría, cuál es el proceso que realizan para decidir dónde consideran que "dice sobre abejas", es decir, cómo arriban a las respuestas sean o no correctas- procurando atender a diversas informaciones provistas por el texto, por las imágenes y por el investigador.

Analizaremos, de manera pormenorizada los recorridos: cómo los niños sostienen su elección inicial o cambian de parecer en función de la interacción con el objeto libro y los contraejemplos que propone el adulto; quiénes y qué información toman en cuenta y qué justificaciones proponen para sostener su elección. En los apartados siguientes organizamos la presentación de los resultados de acuerdo con el siguiente orden: en primer término, expondremos de manera más detallada los dos recorridos que culminan en la elección correcta y en segundo término los recorridos que culminan en la elección incorrecta.

4.4.5.1. Recorrido $A B+:$ niños que arriban a la página de las abejas y concluyen en ella a pesar del contraejemplo

Como señalábamos en el Gráfico 5 , un $40 \%$, es decir, $47 / 117$, son aquellos que no han modificado la decisión correcta inicial. Para ello, al hojear el libro han salteado la página de avispas -ubicada doce antes que la de abejas- para llegar y elegir esta última. Es decir, toman el libro y comienzan la búsqueda, se detienen en la página de las abejas y sostienen esa elección a pesar del contraejemplo del adulto.

Recordemos que, de las 47 respuestas, un $27 \%$ pertenece a Jardín y un $53 \%$ a Primer Grado (Grafico 6). En la Tabla 1, que aparece más adelante, puede observarse que el porcentaje de Jardín está integrado por 16 respuestas: 5 de Jardines X (JX) y 11 de Jardines $Z(J Z)$ y el porcentaje de Primer Grado está constituido por 31 respuestas: 11 de Escuelas $X(P X)$ y 20 de Escuelas Z (PZ). 
Los niños que efectúan este recorrido han tomado en cuenta diferentes indicios para efectuar su elección inicial, justificarla y enfrentar las intervenciones del investigador:

a) Seleccionan la imagen de abejas y la utilizan como justificación privilegiada.

b) Seleccionan la imagen de abejas y recurren a lo escrito para dar su justificación.

c) Recurren inicialmente a las escrituras para justificar su elección.

Las respuestas encontradas en el marco de la presente investigación son coincidentes con el tipo de respuestas obtenidas en investigaciones precedentes donde se les propone a los niños situaciones de interpretación de escrituras acompañadas de imagen (Ferreiro y Teberosky, 1979; Ferreiro, 1997). Estas investigaciones pusieron de manifiesto que los niños recorren un camino de coordinaciones progresivas entre la imagen y el texto que la acompaña: en primer término con predominio del peso de la imagen y, posteriormente, tomando en consideración rasgos cuali o cuantitativos del texto para efectuar anticipaciones de significado. En nuestro caso, las respuestas brindadas por los niños de los grupos estudiados transitan un camino similar.

La siguiente Tabla muestra la distribución de las respuestas en Jardín y Primer Grado X y Z.

Tabla 1: Cantidad de respuestas según tipo de procedimientos de los niños que arriban a la abejas y concluyen en ella a pesar del contraejemplo $(\mathrm{AB}+)$. $\mathrm{N}=47$.

\begin{tabular}{|l|c|c|c|c|c|}
\hline & JX & JZ & PX & PZ & TOTAL \\
\hline $\begin{array}{l}\text { a) Seleccionan la imagen de abejas y la } \\
\text { utilizan como justificación privilegiada }\end{array}$ & 3 & 2 & 5 & 2 & 12 \\
\hline $\begin{array}{l}\text { b) Seleccionan la imagen de abejas y } \\
\text { recurren a lo escrito para dar justificación }\end{array}$ & 2 & 2 & 2 & 11 & $\mathbf{1 7}$ \\
\hline $\begin{array}{l}\text { c) Recurren inicialmente a las escrituras } \\
\text { para justificar su elección }\end{array}$ & 0 & 7 & 4 & 7 & $\mathbf{1 8}$ \\
\hline TOTAL & $\mathbf{5}$ & $\mathbf{1 1}$ & $\mathbf{1 1}$ & $\mathbf{2 0}$ & $\mathbf{4 7}$ \\
\hline
\end{tabular}

En las respuestas de los Jardines $X$ y $Z$ se constatan notorias diferencias en las respuestas $c$ ), es decir, las respuestas más avanzadas: solo los niños de jardines $Z$ brindan respuestas de este tipo: 7 de un total de 11. Las respuestas del tipo a) y b) están representadas de forma pareja.

En Primer Grado, considerando cada tipo de escuela, en las respuestas de $\mathrm{X}$ las interpretaciones centradas en la imagen son casi la mitad: 5 de un total de 11. En las Escuelas Z este tipo de 
respuestas tiene escasa presencia, 2 de un total de 20. Tal como puede apreciarse en la Tabla 1, en las Escuelas $X$ predominan las justificaciones que seleccionan la imagen como dato privilegiado para decidir dónde dice sobre las abejas, mientras que en las $Z$ las justificaciones se basan más en la escritura.

Comentaremos y ejemplificaremos cada uno de estos tipos de respuestas.

a) Seleccionan la imagen de abejas y la utilizan como justificación privilegiada

Doce niños de un total de 47 (Tabla 1) seleccionan la página de abejas otorgando a la imagen todo el peso de la justificación: toman el libro, lo hojean haciendo foco en algún o algunos aspectos de la imagen y sostienen la justificación centrada en las ilustraciones aún cuando el adulto sugiere recurrir a lo escrito.

Algunos niños justifican su decisión señalando en la imagen la presencia del insecto: "Hay Abejas", "Porque ahí están", "Están los dibujos". Otros, además, incluyen mayor explicitación entre lo que la ilustración muestra y el conocimiento que tienen sobre estos insectos: "Porque estas dos cosas te enseñan" (señala panal y flores de páginas de abejas), "Porque ellos comen las flores (en página de abejas) y acá (en avispas) no hay flores hay otras cosas". "Porque está buscando miel en las flores y está en el panal"; "Y comen plantas" (señala el dibujo de la colmena), "Acá, porque no tiene como acá (ilustración de flores) pero están también las abejas".

b) Seleccionan la imagen de abejas y recurren a lo escrito para dar justificación

A diferencia de las respuestas anteriores, en este caso 17 niños toman la imagen como la justificación inicial pero apelan a lo escrito para sostener su selección y resistir el contraejemplo. Como podemos observar en la Tabla 1, hay más respuestas que recurren a lo escrito en Primer Grado que en Jardín ( $J=4: P=13)$. Entre los Jardines $X$ y $Z$, el número de respuestas es parejo: 2 en cada uno; en Primer Grado, en cambio, el contraste entre escuelas es notorio, a favor de las Escuelas $Z(P Z=11$ y $P X=2)$. Aquí los niños ponen en juego conocimientos sobre el sistema de escritura, es decir, coordinan información considerando algún dato cualitativo del texto que les permite argumentar y sostener su elección inicial. En todos los casos, cuando el investigador los invita a considerar otra información a través de una pregunta: “¿además de la imagen, en qué otra cosa podés fijarte para estar seguro/a?", este conjunto de niños -a diferencia del anteriorconsidera de inmediato la pregunta del adulto y acude al texto para sostener la decisión inicial. 
Estos alumnos pueden sostener su elección atendiendo a datos de las escrituras constatando la identidad de uno o ambos extremos de ABEJAS/AVISPAS y explorando luego las letras diferentes para justificar su decisión. En algunos casos focalizan y cotejan los titulares de las páginas; en otros, apelan también a algún subtítulo. Inclusive, hay niños que resolvieron utilizar el íNDICE de la enciclopedia a fin de localizar la información buscada. Finalmente, algunos llegan a leer convencionalmente a pesar de haber esgrimido como primera justificación las imágenes.

Veamos algunos ejemplos:

Augusto, de PZ, realiza una centración en las vocales diferentes -E/l - para sostener la elección de la página de abejas y rechazar la de avispas, explorando los titulares.

Alumno: Acá (dibujo pág. 25 de abejas).

Investigador: ¿Para saber rápido dónde dice sobre las abejas dónde te fijas?

A (marca dos subtítulos: DATOS DE INTERÉS y ABEJAS ASESINAS. En datos de interés, el Primero de la pagina 25, abejas asesinas).

I: Un nene me dijo que en esta página (12 y 13) era para saber sobre las abejas. ¿Qué pensás?

A(Duda): Son las mismas letras: ¿Cuáles? (Mira ambas páginas, luego de un rato dice): Acá (AVISPAS), no está la E (Comparando los titulares de la página de AVISPAS y de ABEJAS). Acá es abejas (página de abejas) porque tiene 'e'.

Victoria de JX también identifica ABEJAS por la 'e' y, en la comparación entre títulos ABEJAS y AVISPAS, considera la ' $i$ '.

Investigador: ¿Cómo podés saber dónde dice sobre las abejas?

Alumno: Mirando las hojas (hojea). Acá (ilustración página de abejas) porque veo abejas.

I: ¿Y en qué otra cosa te podés fijar?

A: (No responde).

I: Un nene que vino antes me dijo que en esta otra página (muestra la página de avispas) puede decir sobre las abejas...

A: Sí, porque también hay una abeja (señalando la ilustración de avispas).

I: Y si yo te digo que sólo en una página dice... ¿cuál elegirías?

A: Acá (señala ilustración de abejas), porque está dibujada, este es el panal, y en esta está la flor (ilustración página 25).

I: ¿Sabés qué es esto? (Título ABEJAS)

A: Acá dice abejas (señalando título ABEJAS) porque está la 'be' y la 'a'.

I: En este de acá también están la 've' y la 'a' (señalando AVISPAS).

A: En la otra hoja está la 'e' (E en ABEJAS) y acá está la "i". 
I: ¿Para 'abeja' tiene que estar la 'e'?

A: Sí, dice a/ be/jas (leyendo título)

En las primeras respuestas, la niña justifica su elección por la imagen "porque veo abejas". A partir de la solicitud del investigador "¿Sabés qué es esto?", toma en cuenta las dos vocales mencionadas para diferenciar ambas palabras: la 'e' en "abejas" y la 'i' en "avispas".

Algunos niños llegan a realizar exploraciones más exhaustivas para reforzar su elección. Celina, de PZ, constituye un ejemplo interesante de rastreo.

Alumno: A ver... (Agarra el libro, hojea mirando y deteniéndose en cada página hasta que llega a la de abejas) Sobre las abejas encontré yo acá.

Investigador: ¿Por qué te paraste en esa página?

A: Porque tenía dibujadas tres abejas.

I: ¿Y cómo estás segura que eso es de abejas?

A: Porque las abejas sacan la miel de las flores, entonces acá (señala dibujo pág.25)

I: Claro, pero un nene el otro día me dijo que acá también era de abejas (Página12 de avispas). ¿Qué te parece a vos?

A: Donde dice su nombre: ¿dice el nombre, "abejas"?

I: ¿Y dónde puede decir? Es muy interesante tu pregunta.

A (Toma con una mano la página de las avispas y con la otra en la de las abejas): Ahí me fijo...

I: A ver... ¿ ¿ónde dirá?

A: (Mira y señala en Página 13 el subtítulo LA AVISPA SOLITARIA) En ninguna de todas, porque mirá, no empiezan ni con la 'a', ésta empieza con la de "Laura"( En LA del subtítulo), ésta empieza con la de "Vero" ( $V$ en AVISPA) ésta empieza con la de "Sol"(en SOLITARIA). Tiene que empezar con la 'a'... (pasa a la página de las abejas) Ésta es.

I: ¿Cómo podés saber rápido?

A: Acá. A-be-ja. (ABEJA página 24)

I: ¿Qué es eso?

A: Donde dice abeja. Acá también dice abeja...a-be-jas (en subtítulo ABEJAS ASESINAS). Lo que pasa (vuelve a página de las avispas) ab...¿ésta cuál es? (V en AVISPAS) Acá (señala V) va la de bebé, y acá (vuelve a página 24, marca $B$ ) está la de bebé...

I: ¿Y dirá "abejas" ahí?

A: Abe... abe... be...jas. Dice acá. (En título de pág. 24)

I: ¿Y acá qué dirá? (página 12)

A: ¿A ver? No. No dice 'abejas'.

I: ¿Por qué? 
A: Porque no tiene la de bebé, ni ninguna que lleva. Tiene la 'a', bueno, la 'a' sí tiene, pero después las demás no, no tiene la 'e', no tiene la "jota", no tiene la 'a', bah, la 'a' sí la tiene y justamente no tiene la "jota".

Celina, como los otros niños, toma en cuenta índices del texto para justificar su elección. Identifica varias letras, algunas por su nombre, la 'jota', la 'e', la 'i', la 'a'; otras por su pertenencia a nombres conocidos: "empieza con la de Vero", "empieza con la de Laura", "empieza con la de Sol” y otras por ser palabras de uso frecuente ("va la de bebé").

Es interesante advertir la manera en que va ajustando sus propios argumentos cuando se encuentra con los datos de la escritura hasta definir la elección. Hemos encontrado modalidades exploratorias y justificaciones similares en varios niños de las Escuelas $Z$ y ningún caso en las Escuelas X.

Jenifer, también de PZ, hojea y brinda inicialmente justificaciones a partir de las imágenes. Luego toma en consideración datos de la escritura cuando se le presenta un contraejemplo y necesita justificar su elección pero, a diferencia de los ejemplos anteriores, apela al íNDICE de la enciclopedia.

Alumno: Acá (página chinches) no, acá no... (Se detiene en la página de las avispas): Acá no. (Sigue hojeando llega a página 25) Ésta es de las abejas.

Investigador: ¿Cómo estás tan segura?

A: Me doy cuenta porque hay una abeja bebé y van creciendo y se van poniendo más grandes y se van poniendo enteritas y gorditas y acá dice las palabras. (Señala al azar dibujos en página 25)

I: Otro chico a mí me dijo que era acá donde hablaba de las abejas (Página avispas)

A: No, son hormigas acá (Página avispas). Acá se lo comen los gusanos, la hormiga a los gusanos se los comen.

I: ¿Y éste (Ilustración página 13 avispas) que te parece que es? ¿Será de abejas?

$\mathrm{A}$ : $\mathrm{Si}$, es una abeja. Las avispas son estas. (Señala pagina de abejas)

I: ¿Dónde dice de las abejas?

A: En estas también. (Señala paginas de abejas)

I: En realidad hay dos hojas que hablan de las abejas no más, ¿cómo podemos saber cuál es cuál?, ¿cuál es de las abejas y cuál no? Vos me mostraste muchos dibujos, pero para estar seguros ¿Qué otra cosa podemos mirar?

A: Esta, ésta, que está verde. (Señala un dibujo de hojas en la página de abejas)

I: ¿Qué podemos mirar para estar seguros?

A: El Índice.

I: ¿Dónde estará el Índice? 
A: Es éste. (Lo busca y señala correctamente)

I: ¿Cómo hacés para usar el Índice?

A: Un número,

I: Buscá abejas a ver si está.

A: Abejas. Es éste. (Señala correctamente)

I: ¿Ahí que dice?

A: Abejas. Está bien. ¿no?

I: A mí me parece que puede ser este o puede ser éste. ( señala abejas y avispas)

A: Este porque tiene la jota de Jennifer y el número es ¿éste que número es?

(Va a página abejas y coteja que es el mismo número)

A: Acá, acá dice abejas (señala título principal y lee señalando)

Tal como se advierte en el registro, Jenifer, después de identificar palabras a partir de ciertas letras conocidas, recurre espontáneamente al ÍNDICE del libro. Este dato no es menor, porque pone de manifiesto la inmersión de la niña en un ambiente alfabetizador en el que los libros no solo están a su alcance sino que han sido mediados por un informante acerca de ciertas características que los niños no pueden descubrir por sí mismos. Este tipo de reacción evidencia la participación de Jenifer en prácticas de lectura cotidianas, que tienen lugar en las aulas de las Escuelas Z.

También en los casos de los niños que ya leen de manera más autónoma - aunque todavía con cierta dificultad - la imagen tiene peso y parece ser el primer dato que consideran para decidir dónde dice sobre abejas.

Un interesante ejemplo es el de Camila de PZ, que ingresa por la imagen y su justificación inicial remite a ella. Hojea todo el libro, lo cierra y lo abre, vuelve a hacerlo por segunda vez. Se detiene en la páginas 24 y 25 (abejas) justifica por la imagen y frente a la pregunta ¿Cómo podemos estar seguros? se remite a leer el primer párrafo. En este caso, la niña corrobora su elección leyendo un fragmento del cuerpo del texto.

Alumno (vuelve a hojear, llega a abejas, se detiene, mira los dibujos de la páginas 24 y 25 )es una abejita, para mí es una abejita.

Investigador:¿Cómo podemos estar seguros?

A: Tenemos que leer... a ver que dice..." el hom-bre -lle-va- si-glos- do-mes-ti-can-do..." no, no dice abejas (continúa leyendo)"co-mo- ta-les- po-de-mos- re-se-ñar... si, es abeja.... "el hombre ha aprovechado la cera y la miel de las abejas... si, es ésta.

I: ¿y ésta no puede ser de abejas? (Señala página de avispas) 
A: También puede ser porque hay dibujos de abejas, voy a leer.... lee "el -de-sa-rro-llo deavis-pas-"es avispa

I: Y esto que és? (Señala títulos)

A: Es el Título.

I: ¿Para qué sirve?

A: Para saber y para leer-

I: ¿Y para encontrar nos sirve?

A: Mejor tenés que leer como hice yo.

Lo interesante de este caso es que la niña considera que la información brindada por un humilde título no es suficiente para tener certeza acerca de la pertinencia de una elección: para encontrar "mejor tenés que leer como hice yo".

Podríamos decir que los niños incluidos en el grupo de respuestas del tipo b) muestran cierto grado de autonomía en la búsqueda de justificaciones utilizando el libro. Los procesos que realizan dan cuenta de que han estado en más de una oportunidad con libros de estas características en sus manos. Los comentarios y preguntas del investigador son puntos de partida para explorar el texto, estos niños usan el libro: van y vienen en las páginas y logran procedimientos personales de comparación entre las palabras, coordinando informaciones. Como ya hemos mencionado, un dato a considerar es que los niños que realizan este tipo de justificaciones pertenecen a Escuelas Z. Los cuatro niños de las Escuelas X que dan este tipo de respuestas, apelan solamente a la identificación de ciertas letras que son tomadas como indicios para la identificación de la página de las abejas.

c) Recurren inicialmente a las escrituras para justificar su elección

Los niños que se circunscriben a este tipo de respuesta, a diferencia de los dos anteriores, justifican directamente apelando por sí mismos a las escrituras, no por sugerencia del investigador.

Encontramos dos formas de justificar la elección apelando a las escrituras:

- Recurren al ÍNDICE del libro y localizan la página de abejas.

- Hojean el libro leyendo los títulos de las diferentes páginas.

Como muestra la Tabla 1, son 18 respuestas que se incluyen en este tipo de justificación. Del total, 14 corresponden a las Escuelas $Z$ y 4 a las X. En las Escuelas $Z$, las respuestas se 
distribuyen por partes iguales entre Jardín y Primer Grado, mientras que las 4 de X corresponden a alumnos de Primer Grado.

De esas 18 respuestas, 9 seleccionan la página de abejas buscando en el ÍNDICE y cotejan luego con la página seleccionada. Esto lo realizan los 7 niños de Jardines Z y 2 de Escuelas Z. Las 9 respuestas restantes, todas de Primer Grado -5 de Escuelas $Z$ y 4 de X- leen los títulos principales que están presentes en cada una de las páginas hasta arribar a la de las abejas.

A continuación, expondremos algunos ejemplos de los dos tipos de procedimientos.

Lectura en el ÍNDICE del libro y localización de la página de abejas

Los niños que apelan en primera instancia al ÍNDICE para ubicar la página solicitada, al abrir el libro lo buscan de inmediato y allí la palabra "abejas" en la lista, siguen la línea punteada hasta llegar a los números que indican la página; luego, hojean el libro hasta llegar a la página de las abejas. La mayoría de los niños lo busca en las páginas iniciales.

Transcribiremos algunos de los comentarios que acompañaban estas acciones:

"Tengo que ver el Índice" (abre y busca el Índice)

"En el Índice tendríamos que buscar"

"Te tenés que fijar en esta página" (mostrando el Índice)

"Si no encontrás la página venís acá tenés que leer y después el cosito, como si fuera esto, vos tenés que hacer así como si estuviera en esta página. (Va al Índice)

"Porque tiene números y letras. Para buscar los libros y lo que querés leer. "Pasás la hoja despacito porque si no se rompe"

“En el Índice. Números para saber dónde está. En veinticuatro están las abejas. (Muestra la numeración de página)

Un niño busca el ÍNDICE al final del libro, un procedimiento pertinente ya que en muchos libros así aparece.

“Índice. En la última página (busca) No. (Continúa buscando). En la primera página”.

Tal como hacemos los adultos, una vez que lo localizan, buscan la palabra "abejas" y siguen la línea punteada hasta llegar a los números que indican la página. Es interesante comentar que algunos niños no leen los números convencionalmente y buscan la página a partir de identificar los dígitos que los integran: 
"El número es el dos, cuatro y el dos, cinco".

En cuanto a sus posibilidades lectoras, algunos identifican la primera letra:

"Porque empieza con la a 'a' "Abejas".

Otros reconocen otras letras como la "be":

"Vila 'a', la 'be'".

"Porque está la 'be' y también la 'ese' lleva para mí, pero no se escucha".

"A - bejas por la 'a' y por la 'be' a (A) -be (BE) acá (señalando ABEJAS) porque tiene la a".

Algunos miran los números de las páginas cotejando con el que vieron en el ÍNDICE de la enciclopedia como lo hace Ricardo de un Jardín Z:

(Hojea mirando los números. Se detiene en la página de avispas y duda. Sigue buscando, observa los números de página. Se detiene en la página de las abejas).

A: Acá, este es de las abejas.

I: ¿Y cómo estás seguro?

A: Porque tiene el numerito y también tiene lo mismo que yo leí (Se refiere a la palabra abejas que vio en el Índice. Señala ABEJAS).

I: ¿Y qué dice?

A: a (A)-be (BE)-ja (JA)

Ricardo coordina información entre lo que leyó en el título y lo que lee en la página. Identifica la palabra por la identidad de lo escrito.

Juan Manuel también de un Jardín Z afirma en la página:

"Acá. Porque estoy en la página veinticuatro y veinticinco.

Hojean el libro leyendo los títulos de las diferentes páginas

Otra manera de ingresar a la tarea atendiendo a lo escrito, es hojear y leer los títulos principales que están presentes en las páginas. Como ya hemos mencionado, la información relativa a cada insecto se desarrolla en doble página, el título -nombre del insecto -sustantivo común, sin artículo- ocupa sólo una de ellas, la página de la izquierda. Los títulos son particulares de este tipo de libros, donde la tipografía se caracteriza por la letra de imprenta mayúscula de un color 
diferente (azul) al de los párrafos (negro). Estos niños advierten que los títulos son nombres y que 'abejas' un nombre entre los nombres.

Como figura en la Tabla 1 , nueve niños realizan este tipo de procedimiento, todos de Primer Grado. Cuatro pertenecen al grupo $X$ y los cinco restantes al $Z$.

Transcribiremos tres ejemplos:

(Toma el libro hojea mirando los títulos) "ABEJAS, acá dice "abejas". Porque arriba dice 'Abejas'. [PZ Manuel]

"Acá, acá está. Ves, este título dice a-be-jas" (lee el título principal) "Porque leí el nombre, yo seguí buscando en cada hoja y encontré el título que dice abejas" (...) [PZ María Victoria]

Álvaro de PX toma el libro y lo hojea, mientras pasa las páginas lee los títulos, llega a la página de las avispas y se detiene)

"No, acá no. Acá (dice) a-vis pas. No. (Sigue hojeando) Es- cor-pio-nes. Man-tis. Mos- cas. Abe-jas ¡Acá! Estas son abejas. Porque dice acá" (señala ABEJAS) Frente a la pregunta del entrevistador acerca de cómo le explicaría a otro nene, Álvaro no responde. [PX Álvaro] 


\subsubsection{Recorrido AV+: niños que arriban a la página de las avispas y cambian de opinión} culminando en la página de las abejas

Como señalábamos en el Gráfico 5 , un $32 \%$ del total de las respuestas (37/117) corresponde a niños que han modificado su decisión inicial de la siguiente manera: al hojear el libro eligen la página de avispas que está antes que la de abejas y luego cambian de parecer frente al contraejemplo del adulto.

¿Qué hace que los niños cambien su elección inicial? ¿En qué se apoyan para hacerlo? ¿Qué recursos utilizan para sus justificaciones? ¿Qué informaciones están coordinando?

En esta categoría encontramos tres maneras de responder a los problemas que se les plantean, muy similares a las que encontramos para los $\mathrm{AB}+$.

a) Ingresan por la página de las avispas y terminan en la de las abejas justificando exclusivamente por la imagen.

b) Ingresan por la página de las avispas y terminan en la página de las abejas justificando su cambio de opinión en función de la imagen y de ciertos aspectos de las escrituras.

c) Ingresan por la página de las avispas y terminan en la página de las abejas, identificando elementos paratextuales del libro y utilizando alguno de ellos para dar su justificación. 
La siguiente Tabla muestra la distribución de las respuestas en Jardín y Primer Grado X y Z.

Tabla 2: Cantidad de respuestas según tipo de procedimientos de los niños que arriban a la página de avispas y concluyen en la de abejas (AV+). $\mathrm{N}=37$

\begin{tabular}{|l|c|c|c|c|c|}
\hline & JX & JZ & PX & PZ & TOTAL \\
\hline $\begin{array}{l}\text { a) Ingresan por la página de las avispas y } \\
\text { terminan en la de las abejas justificando } \\
\text { exclusivamente por la imagen. }\end{array}$ & 6 & 0 & 2 & 1 & $\mathbf{9}$ \\
\hline $\begin{array}{l}\text { b) Ingresan por la página de las avispas y } \\
\text { terminan en la página de las abejas recurriendo } \\
\text { a la imagen y a características de las escrituras } \\
\text { para justificar su cambio de opinión. }\end{array}$ & 2 & 8 & 5 & 4 & 19 \\
\hline $\begin{array}{l}\text { c) Ingresan por la página de las avispas y } \\
\text { terminan en la de las abejas, centrándose en } \\
\text { datos de las escrituras para justificar su cambio } \\
\text { de opinión. }\end{array}$ & 0 & 5 & 1 & 3 & $\mathbf{9}$ \\
\hline TOTAL & $\mathbf{8}$ & $\mathbf{1 3}$ & $\mathbf{8}$ & $\mathbf{8}$ & $\mathbf{3 7}$ \\
\hline
\end{tabular}

De las 37 respuestas, 21 corresponden a Jardín y 16 a Primer Grado.

En la Tabla 2 observamos que en los Jardines $X$ hay mayoritariamente respuestas del tipo a), es decir, que utilizan la imagen como justificación. No encontramos ninguna respuesta de este tipo en Jardines Z. Los niños de estos Jardines, si bien utilizan la imagen para justificar su elección, coordinan esa información con datos de las escrituras. Por otra parte en los Jardines $Z$ hay 5 respuestas que toman en consideración datos de las escrituras (respuestas del tipo c), mientras que en los Jardines $X$ ningún niño los toma en cuenta.

A diferencia de Jardín, en Primer Grado hay poco contraste entre las diferentes subcategorías, aunque cabe señalar en los Primeros Grados $Z$ hay tres respuestas del tipo c). Esto ocurre en un solo caso de los Primeros Grados de las Escuelas X.

Comentaremos y ejemplificaremos las diferentes respuestas.

a) Seleccionan la página de las avispas y terminan en la de las abejas justificando exclusivamente por la imagen.

Estas nueve respuestas - ocho de las cuales corresponden a niños de las Escuelas X - cambian de opinión a partir del contraejemplo pero no logran tomar índices del texto para completar su justificación. 
Todos comienzan la tarea hojeando y se encuentran con la página de las avispas antes que con la de abejas. Se centran en algún aspecto de la imagen como podemos advertir en las siguientes frases:

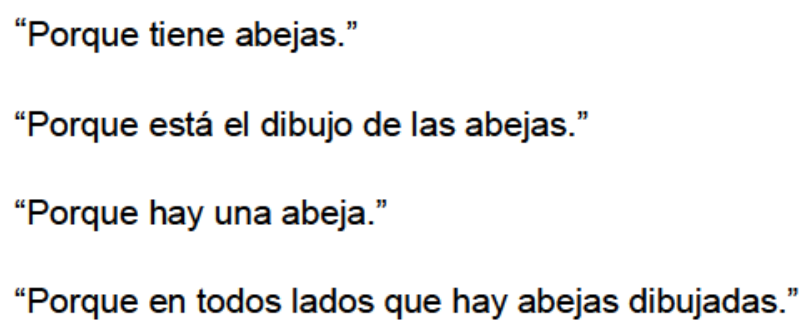

Cuando el adulto presenta el contraejemplo -mostrando la página de las abejas- estos niños cambian de opinión y en sus justificaciones aparecen ciertos intentos de coordinación de información entre lo que saben acerca de estos insectos y las ilustraciones de las páginas:

\footnotetext{
"Está el panal" (Señalando la ilustración de la página 25)

"Sí. Porque están haciendo la miel."

"Sí, porque está sacando la miel de las flores."

"Acá hay una abeja con miel."

"Acá porque está la abeja sacando de las flores miel y porque la abeja siempre toma el juguito de la flor."
}

Ninguno de estos niños logra justificar con algún aspecto del texto a pesar de la sugerencia del investigador: se centran en las imágenes tanto en su elección inicial como en la final. En este caso, no es descartable que el cambio de idea pueda estar influido por el peso de la opinión del adulto.

b) Ingresan por la página de las avispas y terminan en la página de las abejas justificando su cambio de opinión en función de la imagen y de ciertos aspectos de las escrituras.

Los niños de este grupo también ingresan a la tarea hojeando la enciclopedia guiados por las imágenes. Frente al contraejemplo, aceptan la sugerencia del investigador. A diferencia del grupo anterior toman índices cualitativos de los textos para justificar la nueva elección o llegan a leer, tal como hacían los alumnos que daban respuestas del tipo b) de la categoría $A B+$. 
Algunos ingresan por la imagen y luego para justificar hacen un cotejo entre las palabras "avispas" $y$ "abejas" haciendo énfasis en la diferencias entre "V" y "B" como letras diferenciadoras como se puede observar en los ejemplos que siguen.

Candelaria, de un Jardín X, sabe el nombre de la 'be' larga y la señala como diferenciadora entre ambas palabras; también reconoce la 'e' que distingue de la 'i' en "avispas" enfatizando con eso su cambio de elección de página:

Alumna: (Hojea) Acá (se detiene en la página de avispas).

Investigador: ¿Cómo sabes que hay ahí?

A: Porque hay una oveja, una abeja (ilustración Pág. 13: AVISPAS)

I: ¿Dónde más podrías fijarte para estar segura?

A: En otras hojas... encontré una abeja (Pág. 24 y 25 ABEJAS)

I: ¿Entonces, ¿cuál es?

A: Acá hay muchas. Hay muchas cosas de abejas acá.

I: ¿Cuál será la parte que habla sobre abejas?

A: La de adelante y esta (refiriéndose a las páginas de AVISPAS y ABEJAS).

I: Pero si te dijera que solo una habla de abejas..

A: Estas no son abejas (señalando las ilustraciones de la página 24: ABEJAS).

I: ¿Qué me dijiste sobre las abejas?

A: Que posaban de flor en flor y que cuando traían todo la llevaban a la colmena y la ponían en estos cositos (señalando ilustración de la página 25).

I: ¿Entonces en que página habla sobre las abejas?

A: En esta (señala páginas 24 y 25) porque ésta está bien porque acá esto siempre está marrón y esto está verde (refiriéndose a la ilustración del panal).

I: ¿Qué es lo marrón?

A: Son los cositos para que ponga la miel ahí.

I: ¿Y además de los dibujos nos podemos fijar en otra cosa?

A: Acá (ilustración de tapa) en la tapa porque acá están todos los bichos que están en el libro.

I: Pero primero pensamos que era en este sector (Pág. avispas), después en este otro (Pág. abejas), ¿cómo podemos estar seguros?

A: No sé.

I: ¿Esto de acá arriba qué es? (Refiriéndose al título).

Hasta aquí Candelaria centra sus justificaciones en las imágenes y poniendo énfasis en ellas logra cambiar de opinión. A partir de la última pregunta del investigador mira el título:

A: No sé, esto no sé que es... letras. 
I: ¿Qué dirán estas letras?

A: Abejas.

I: ¿Por qué?

A: Porque yo sé que la abeja empieza con la 'a'.

I: Pero la que habíamos encontrado antes también empieza con 'a'.

Identifica la letra inicial y frente al contraejemplo con "avispas" que le brinda el investigador, Candelaria repara en las 'be':

A: Pero acá esta la ve (AVISPAS) y acá está la be larga (ABEJAS) acá está la 'e' (ABEJAS) y acá no está la 'e', está la "i" (AVISPAS).

Gaspar, de un Jardín Z, después de justificar su elección de la página de avispas por la imagen, también recurre a lo escrito señalando un subtítulo e intentando leer "abejas" en "avispas".

A: ¡Si! acá dice abejas (AVISPAS)

I: ¿Cómo te das cuenta?

A: Porque empieza con la 'a' y termina con la "ese".

I: Pero mirá acá (va a una de las páginas de abejas) también empieza con la 'a' y termina con la "ese" (ABEJAS) ¿En dónde dirá abejas acá o acá? (ABEJAS / AVISPAS)

A: A ver dejame leer (se concentra en AVISPAS da vuelta la página y se concentra en ABEJAS. Lee señalando las letras de ABEJAS) Acá dice abejas a-be-jas.

I: ¿Cómo te diste cuenta?

A: Porque tiene la de...

I: ¿Cuál?

A: (marcando cada letra) La 'a' la "be" la 'e' la "jota" la 'a' y la "ese"

I: Por eso estás seguro ¿Y no podría decir "abejas" acá? (señala AVISPAS)

A: A ver... no. A - be, no, porque necesitaría una "jota" acá en el medio (señala SP) y acá una 'e' (señalando la "i"), a ver una de "jota", acá una "a" y una "ese" (compara ambas escrituras: va mirando cuáles están en ABEJAS para ver si están en AVISPAS).

Gaspar hace un cotejo cuidadoso entre las dos palabras y toma la decisión correcta, apoyándose en la información que posee sobre las letras. Esto le permite tener mayor certeza para cambiar de opinión responder adecuadamente a la pregunta final del investigador. 
Rocío de un Jardín Z, logra llegar a la página adecuada, modificando su elección inicial que había justificado por la imagen. Después de señalar la imagen en la página de las avispas, sigue hojeando y, mientras hojea, mira los títulos y dice:

“Abejas termina con la 'ese'. Tiene que empezar con la 'a'. (Mira AVISPAS, se detiene, sigue hojeando y llega a ABEJAS. Vuelve a mirar AVISPAS): "Termina con la 'ese' y tiene la 'a' la 'pe' y la 'ese'".

El investigador vuelve a la página de las abejas y le pregunta si ahí podrá decir "abejas". Rocío mira cuidadosamente $y$, finalmente responde:

"Sí, acá (ABEJAS) dice "abejas" porque tiene la 'be' de Brisa, la 'be' de abejas."

Esta niña toma su decisión final, en virtud de reconocer la letra del nombre de una compañera de la sala, a la que denomina "la 'be' de Brisa".

Veamos otros ejemplos. Algunos encuentran la palabra en el título y les resulta suficiente. Otros, mayoritariamente alumnos de las Escuelas Z, proceden a comparar lo que identifican en el título con alguna otra escritura, a fin de confirmar con mayor certeza si se trata de la página buscada.

Nerina de una Escuela $X$ señala el título de AVISPAS, luego cambia a la página de abejas. No mira otro lugar para asegurarse.

Alumna (hojea y se detienen página 12): Acá.

Investigador: ¿Dónde te fijaste para saber que es de abejas?

A: Porque está en la tapa. (Es la misma imagen)

I: Está en la tapa pero vos me dijiste que en esta página hay sobre las abejas, ¿Cómo te diste cuenta?

A: No sé...

I: ¿Cómo podés saber que ahí es de abejas?

A: Porque acá dice "avispas (página 12)

I: Buscamos para saber sobre las abejas.

A: Acá es de avispas.

I:¿Buscamos si está en otro lado "abejas"?

A: Este es de escorpiones.

I: Sí.

A: Acá. (Página 24,25)

I: ¿Dice "abejas"? 
A: Sí.

I: ¿Dónde dice "abejas" además de ahí dónde me mostraste?

A nuevamente señala el título, sin tomar en cuenta algunos subtítulos que contienen la misma palabra.

I: ¿Hay algún otro lugar donde diga "abejas"?

A no responde.

Marcos de un Jardín $Z$ recurre al subtítulo ABEJAS ASESINAS y luego coteja con el título principal: ABEJAS.

Investigador:¿Dónde tendrías que leer para saber sobre las abejas? ¿Cómo harías?

Alumna: Corriendo las hojas. (Se detiene en página de avispas)

I: ¿Por qué te parece que es ahí?

A: Porque hay abejas.

I: ¿Te podrías fijar en algo más?

A: No (continúa hojeando el libro. Se detiene en la página de abejas). Acá.

I: ¿Entonces dónde dice sobre las abejas?

A: Esta página (avispas) y esta página (abejas).

I: Pero sólo en una página dice sobre las abejas.

A: Esta (abejas) porque tiene un panal.

I: ¿No podrías fijarte en otra cosa además de los dibujos?

A: Esto (refiriéndose al título AVISPAS de página 14). Avis (AVIS)/ pas (PAS). Avispas. (Hojea y llega a la página de abejas) Acá a/be/jas (ABEJAS), Abejas. A/be/jas (en subtítulo ABEJAS ASESINAS en página 25, que está en una posición destacada de la página) ¿asesinas?

I: ¿Por qué leíste ahí?

A: Porque resulta más fácil, porque son más grandes (refiriéndose al tamaño de la tipografía).

I: ¿Y acá qué dice? (ABEJAS)

A: A/be/jas. Es acá.

c) Ingresan por la página de las avispas y terminan en la de las abejas, centrándose en datos de las escrituras para justificar su cambio de opinión.

La diferencia de estos niños con los de la categoría anterior es que mencionan exclusivamente datos de las escrituras para justificar dónde dice "abejas".

Mirta de un Jardín Z mira los títulos, pareciera estar cómoda en el ir y venir de las páginas:

Alumna: (Hojea y se detiene en las páginas de las avispas) Acá, porque hay una abeja y significa que acá (señala mientras lee AVISPAS en el título)...eh...

Investigador I: Vos señalaste acá arriba, ¿que está ahí? 
A: Avispas.

I: Ajá.

A: No. Espera, voy a buscar otra vez y leer todo lo que dice arriba (refiriéndose a los títulos) y buscar hasta el final. (Hojeando el libro leyendo los títulos) Esta es de hormiga, esta es de chinches, esta de cucarachas, esta es de avispas, esta es de escorpiones, esta de cigarras, esta de mantis, langostas, moscas, acá sí abejas.

I: ¿Y cómo estás segura ahora?

A: Porque acá dice abejas (refiriéndose al título).

Sonia de una Escuela $Z$ realiza un proceso interesante apelando a la comparación entre los títulos principales.

Alumna: (toma la enciclopedia y la hojea. Para en la página de avispas. Mira en silencio) Investigador: ¿Por qué paraste ahí?

A: Acá es de abejas.

I: ¿Cómo te diste cuenta que esta es de abejas?

A (Señalando el título AVISPAS): porque acá dice a- (A)-be (VI)-jas (PAS) (Se queda pensando). Ah, no, está la de Victor... (Señalando la ve corta). No, me equivoqué.

I: ¿Por qué?

A: Porque esta letra no está en abejas.

I: Bueno, entonces seguí buscando.

A: (Continúa la búsqueda mirando hoja por hoja. Se detiene en la página de abejas). Es acá.

I: ¿Cómo te diste cuenta?

A: Hay todos dibujos de cosas de abejas.

I: En la otra página que me mostraste también había dibujos de abejas.

A: Sí.

I: ¿Entonces cuál será?

A: (Se la ve pensativa)

I: ¿Qué otra cosa podés mirar para saber cuál es de abejas?

A: Las letras de acá (señala Títulos)

A: Sí, (Mira una y otra página) es esta (señala la de abejas)

I: ¿Cómo sabés?

A: Porque está la 'a' y la otra BE.

Se detiene en la página de avispas, intenta leer "abejas" en el título. A partir de ahí recurre a un nombre que sabe cómo se escribe - Víctor - y advierte que no es "abejas" porque lleva otra 'be'. Al seguir hojeando se detiene en "abejas" y lo justifica: "está la 'A' y la otra BE". 
lara de un Jardín Z también es un ejemplo de reconocimiento de la 'be' para diferenciar las palabras. A diferencia de Sonia, ella se detiene en uno de los subtítulos de la página de las avispas.

Alumna (abre el libro y empieza a hojear hasta avispas): Acá.

Investigador: ¿Y por qué te parece que hay información sobre abejas?

A: tiene esto (subtitulo LA AVISPA SOLITARIA)

I: ¿Qué es esto?

A: Tiene letras grandes. Porque empieza con esta (L)

I: ¿Qué dice acá? (subtítulo)

A: Oveja.

I: ¿Oveja o abeja?

A: Abeja.

I: ¿Dice abejas acá?

A: No, suena la 'a'.

I: ¿Y esta la 'a' acá?

A: No.

I: ¿Y en otro lugar te podes fijar?

A: Acá (señala AVISPAS, lee) a-(A) be- (VI) ja (SPAS)

I: ¿Dice abejas?

A: No, porque no tiene (dice para sí en voz baja señalando las dos primeras de AVISPAS) a(A) -be (VI ) no, porque no está la be.

I: ¿Y entonces?

A: Cambio de hoja (hojea hasta langosta)

I: ¿Y acá hay? ¿Dice sobre abejas?

A: No (sigue hojeando y para en abejas y señala el subtitulo ABEJAS ASESINAS)

I: ¿Ahí puede decir abejas?

A: Si, suena la 'a'.

I: ¿Y está la 'a'?

A: Si (señala la $A$ en ABEJAS de subtítulo)

I: ¿En otro lugar te podes fijar?

A: Si (señala el título y compara con las del subtitulo) porque tiene lo mismo que hay acá (Refiere a la palabra abejas).

I: ¿Dirá abejas acá? (AVISPAS)

A: No, porque ésta (AVISPAS) no tiene la be (señala B en páginas abejas)

lara ingresa por las ilustraciones y va al texto por la pregunta del adulto. Lee "abejas" en "avispas" y advierte que no está la 'be'. Seguramente no se trata de un conocimiento ortográfico sino de una 
referencia centrada en el conocimiento del nombre de la letra que, en la palabra ABEJA, coincide con la sílaba. Cuando hojea y encuentra la página de abejas, advierte rápidamente la 'be' para diferenciar ambas palabras y es eso lo que le hace cambiar su opinión inicial.

Carolina de una Escuela Z realiza un proceso similar a los dos anteriores, hojea el libro mirando los títulos, se detiene en la página de las avispas y considera que allí dice "abejas". Frente al contraejemplo, Carolina trata de leer el comienzo de un párrafo:

\footnotetext{
Alumna (Intenta leer el primer párrafo de la página 24 "El hombre lleva siglos domesticando a las abejas. Inicialmente vivian en cavidades arbóreas, en hornacinas o en cuevas, donde construían sus panales compuestos por celdillas de cera hexagonales..."): El hombre lla-ma si-glos do-mes-ti-can-do a las abe-jas. Inicialmente vivian en ca-vi-da-des arbo-re..boreso $0 . .$.

Investigador: ¿Qué dice?

A: Que el hombre llama a las abejas y viven en (lee) ca/ bi/ da/ des/ ar/ bo/ reas. Acá hay toda información de abejas.
}

Algunos niños llegan, incluso, a consultar el ÍNDICE del libro para ingresar a la búsqueda.

Melina logra coordinar la información del Índice con la búsqueda en las páginas. En cambio, Ciro comienza su búsqueda allí pero luego va a los títulos principales para buscar dónde dice abejas.

Melina de un Jardín Z ingresa por el ÍNDICE del libro. Inicialmente piensa que "avispas" es la palabra que busca y frente al contraejemplo logra justificar el por qué de su decisión.

Investigador: ¿Dónde tendrías que leer para saber más sobre las abejas?

Alumna: Mirando con el Índice (lo localiza rápidamente).

I: ¿Qué hay?

A: Números y para leer dónde querés ir. Vos buscas el número y vas buscando por el número dónde querés ir.

I: Mostrame.

A: Tenés que leer donde dice abejas.

I: Bueno, leé.

A: Acá (Avispas) porque empieza con la 'a' y termina con la "ese". 
I: Esta también empieza con la 'a' y termina con la "ese"... (Abejas)

A: A/be/jjj. La ge. Esta (abejas) porque tiene la "ge" (j).

I: Ahora, ¿dónde te fijás?

A: En el número. El veinticuatro y el veinticinco. (Hojea mirando números). Acá porque tiene los números que yo dije.

I: ¿Podes fijarte en otra cosa?

A: Porque tiene los dibujos.

I: ¿Y en algún otro lugar?

A: Leyendo.

I: ¿Y qué leerías para saber rápido si es sobre las abejas?

A: Esto (título).

I: Se llama titulo. ¿Qué dice?

A: El título dice, eh, dice abejas.

I: ¿Y cómo estás segura?

A: Porque tiene la "be" y también tiene la "jota" y tiene las letras que necesitaríamos para abeja. 


\subsubsection{Recorrido $A B-$ niños que arriban a la página de las abejas y cambian de opinión culminando en otra página}

En el gráfico 5, ya habíamos señalado que un $8 \%$ del total de respuestas (10/117) eligen inicialmente de manera adecuada la página de las abejas y frente al contraejemplo cambian de opinión; al considerar el contraejemplo como válido su elección culmina en la página de avispas.

Si bien las respuestas de esta categoría constituyen un pequeño porcentaje del total, cabe destacar que casi todas (8/10) se ubican en las Escuelas X. Seis respuestas corresponden a Jardín - cinco de ellas pertenecen a Jardines $X$ - mientras que en el grupo de los Jardines $Z$ hay una sola elección final errónea.

En Primer Grado, de las cuatro respuestas erróneas, tres corresponden a Escuelas X y solo una a Escuela Z.

De los diez casos, siete niños apelan a la imagen para justificar sus elecciones y los tres restantes, además, mencionan letras de AVISPAS para indicar que allí está escrito "abejas".

Estos niños hojean el libro y llegan a la página de abejas. Sus justificaciones esgrimen ideas sobre el tema y todas -inicialmente- están ligadas a la imagen: "Porque tienen alas y tienen estas cositas"; "Lo vi, eso que la abeja está con la miel"; "Porque las abejas meten acá la miel y la sacan de la flor"; "Porque las abejas sacan miel de adentro de esas flores. Otras flores no tienen miel"; "Porque acá tienen sus casas"; "Hay cosas de abejas"; "Hay dibujos de cosas de las abejas"; "Porque chupan flores".

Cuando el investigador contraargumenta con la página de avispas, los niños utilizan algunas de esas mismas justificaciones para cambiar su elección: "Sí, hay también abejas"; "Porque tienen alas y tienen estas cositas" (señalando parte de la ilustración); "Porque hay más abejas". Cuando eso ocurre, el adulto les pregunta en qué otro lugar que no sean ilustraciones pueden fijarse para estar seguros del cambio. Ante este pedido, algunos muestran letras sueltas, o bien hacen un señalamiento global marcando partes del texto sin realizar una localización ajustada, datos que podrían ser interpretados como una respuesta de compromiso.

Es probable que el peso de la opinión del adulto al efectuar el contraejemplo haya tenido efecto en el cambio de opinión, pero también consideramos importante señalar que estos pequeños no logran utilizar ningún dato de la escritura para identificar la página correcta. 


\subsubsection{Recorrido AV-: niños que arriban a la página de las avispas y el contraejemplo no los hace cambiar de opinión}

Estos niños ingresan hojeando, encuentran primero la página de avispas y el contraejemplo del investigador no los hace cambiar de opinión. El Gráfico 5 indica que un $20 \%$ del total de las respuestas (23 de 117) corresponde a esta categoría.

De esas 23 respuestas, 16 corresponden a Jardín y 7 a Primer Grado. Si desglosamos las respuestas de Jardín, 10 son de Jardines X y 6 de Jardines $Z$. En Primer Grado, la diferencia es casi nula: $P X=4$ y $P Z=3$.

En cuanto a los elementos considerados en las justificaciones para la toma de decisiones, la mayor parte de estas respuestas apelan a las imágenes, algunos mencionan letras que no llegan a conformarse en Índices cualitativos y dos niños acuden al ÍNDICE del libro para la búsqueda.

Los niños que esgrimen justificaciones vinculadas a las imágenes, mencionan frases similares a las explicitadas en las respuestas de las otras categorías:

\footnotetext{
"Porque tienen alas y tienen estas cositas"

"Es igual a la de la tapa"

"Porque acá está la abeja" (señalando una avispa)

"Porque la vi dibujada"
}

Varios de ellos, frente al contraejemplo, mencionan aspectos de las imágenes de las avispas centrados preponderantemente en el tamaño y la cantidad que aparece en la imagen:

\footnotetext{
"Porque hay tres y es más grande".

"Hay muchas abejas".

“Acá hay una grande y acá otra”.
} 
Frente a la solicitud del adulto de tomar en cuenta otros datos que no sean los dibujos, algunos recurren al señalamiento de letras. La mayoría dice que "abejas" tiene 'a' por lo que señalan esa letra en diversas partes de la página, aunque mencionen otras letras. Como Mateo de JZ:

Alumno: Porque abeja empieza con la 'a'.

Investigador: Acá también (ABEJAS)

A: En esta (señala AVISPAS globalmente) Porque sí. Esta (AVISPAS) tiene la 'e' y la 'i'.

I: ¿Y abeja tiene la 'e' y la 'i'?

A: Tiene la 'a'.

I: ¿Entonces dónde dice?

A: Acá (avispas) porque tiene la 'a' (vuelve a señalar avispas, señala letra adecuada en renglón final de la segunda columna de texto de pág. 12)

Tres niños, Alejandro, Ciro y Juan Cruz de un Jardín Z saben de la existencia de los ÍNDICES en este tipo de libros. Lo buscan, lo encuentran, explican de qué se trata pero no logran encontrar en la lista "abejas" ni llegar a la página adecuada. Ejemplificamos con fragmentos de Juan Cruz.

Alumno: No tiene coso de los números que tiene los nombres de los cuentos...

Investigador: ¿Estas buscando el ÍNDICE? y fijate si en el libro hay un ÍNDICE como en los cuentos.

(Lo busca y lo encuentra)

I: ¿Qué es el ÍNDICE?

A: Estos son los números (señala números de página) y estos los nombres (señala títulos).

I: ¿Dirá abejas? ¿En qué te tendrías que fijar?

A: Con la de mamá, acá hay dos (Mariquitas- Mariposas) y acá también (Mantis)

I: ¿Y en cual dice abejas?

A: Acá hay igualitas (se refiere a que las tres palabras terminan con S)

I: ¿Y entonces en dónde?

A: En todas empiezan con esta (M) y terminan con esta (S)

I: ¿En cuál dirá abejas? Solo en un lado dice, ¿cuál te parece?

A: En la "ce" de casa (cucaracha) empieza con esta abejas (C)

I: Pero no dijiste que era con la de mamá...

A: A- be- jas con la 'e' con "ce" de casa.

I: ¿En dónde dice abejas? 
A: Empieza con esta ('i' de ÍNDICE).

I: Pero acá dice ÍNDICE y en uno de estos (señala los títulos) dice abejas y ¿qué es esto?

A: Los números donde están las abejas

I: Te podes fijar ¿Cómo haces para fijarte?

A: Con este y este (señala 6-7 y empieza a hojear).

I: ¿Te estás fijando?

A: Me estoy fijando en los números.

Juan Cruz, a pesar de no llegar a la página adecuada, muestra conocimientos del objeto libro: sabe que para buscar información en este tipo de material tiene que encontrar el ÍNDICE en el libro, a pesar de no conocer su denominación social. 


\subsection{Re-Capitulando}

A través de las respuestas de los niños se puede advertir la compleja tarea que requiere localizar información específica. Sin embargo, la mayor parte de los alumnos logra hacerlo utilizando variados indicios en los diferentes recorridos que atraviesan: algunos solo apelan a las imágenes, otros coordinan las imágenes con el texto y otros, además, utilizan elementos paratextuales del libro para asegurarse de que lo que han encontrado es lo que buscaban.

El análisis cuantitativo de los datos puso de manifiesto que los niños de las Escuelas Z logran mayor cantidad de elecciones acertadas que los de las Escuelas X. Por otra parte, también se advierte que los niños que han participado de un contexto de enseñanza organizada en torno al trabajo con los libros, con los que los pequeños sostienen un contacto más fluido y sistemático, han mostrado mayor cantidad de respuestas que toman en consideración las características de las escrituras. Varios de ellos, incluso, llegan a utilizar el ÍNDICE de la enciclopedia para encontrar la página que contiene la información buscada a pesar de que todavía no leen de manera fluida.

Los niños de las Escuelas Z - tanto en Jardín como en Primer Grado - despliegan en mayor medida la posibilidad de "ir y venir" por las páginas cotejando semejanzas y diferencias. Otro dato interesante es la capacidad que evidencian para explicitar los procedimientos que utilizan y la manera en que brindan explicaciones al entrevistador, vinculadas a cómo hacer para localizar la información solicitada. La mayoría de los alumnos de estas escuelas manifiestan una seguridad mayor en sus decisiones, lo que les permite sostener su elección cuando la consideran adecuada y muchos de ellos solo la cambian cuando advierten en el texto algún dato que les resulta convincente. 



\section{CONCLUSIONES}

El objetivo central de esta Tesis era -como hemos consignado en el Capítulo II- investigar determinados conocimientos infantiles vinculados con la inclusión de los niños en el mundo letrado. Nos interesaba, básicamente, contrastar las respuestas de niños que finalizaban el año escolar en sala de 5 de Nivel Inicial y en Primer Grado de la escuela primaria en dos contextos de enseñanza diferentes.

Desde esta perspectiva, indagamos qué indicios gráficos o textuales tomaban en cuenta para identificar dos libros de géneros muy diferentes -un cuento y una enciclopedia- en los que aparecía el mismo tipo de insecto, en el primer caso como personaje del relato y en el otro como objeto de estudio, como así también, las estrategias utilizadas por los alumnos para localizar información específica en una enciclopedia.

Hemos organizado estas conclusiones retomando los datos analizados en los dos últimos capítulos y enhebrándolos con los interrogantes que orientaron la presente investigación. Recordemos el primero de ellos:

1. ¿Qué libro escogen los alumnos para "saber más" sobre las abejas y cuáles son los argumentos que esgrimen para justificar su elección? ¿Hay diferencias en las respuestas de los niños en función del nivel de escolaridad y contexto de enseñanza? En caso afirmativo, ¿cuáles son?

El análisis cuantitativo vinculado con la elección del libro para "saber más" sobre las abejas nos permitió advertir que el $71 \%$ de los niños selecciona el libro adecuado. Al desglosar este porcentaje en virtud del nivel de escolaridad y el contexto de enseñanza, se constata que no hay grandes diferencias entre las escuelas X y Z (Gráfico 2, Capítulo III).

Es en el análisis de los argumentos que esgrimen los niños para justificar su elección donde surgen diferencias interesantes entre los alumnos de las escuelas con prácticas de enseñanza contrastantes.

Los diferentes aspectos de los libros que tomaron en cuenta los niños de las Escuelas Z pusieron en evidencia mayor conocimiento de los textos en cuestión. Asimismo, consideramos relevante resaltar la responsabilidad con que asumían la tarea y la manera en que tomaban los libros en sus manos, los observaban y los hojeaban mientras esgrimían sus opiniones. La categorización de las 
respuestas se basó, precisamente, en qué aspectos tomaron en cuenta los niños para justificar su elección:

- Justificaciones que sólo atienden a las ilustraciones.

- Justificaciones que ponderan algunas características materiales de los dos libros.

- Justificaciones que toman en cuenta ciertos rasgos específicos de los textos literarios y/o de los enciclopédicos.

En estas conclusiones comentaremos las justificaciones correspondientes a la última categoría porque es la más vinculada con la inmersión en la cultura letrada. Tal como se señalara en el Capítulo III, estas respuestas podrían estar dando cuenta de un conocimiento que suele provenir de haber participado en prácticas de lectura con enciclopedias y cuentos. Los niños consideran ciertos rasgos específicos vinculados con las funciones y tramas predominantes en ambos textos: en el texto enciclopédico se privilegian la función informativa y la trama descriptiva y/o explicativa; en el cuento la función es, lógicamente, literaria y predomina la trama narrativa.

En Primer Grado, el $45 \%$ de la población de las Escuelas $Z$ accede a utilizar argumentos de esta naturaleza: "es cuento / no es cuento"; "es cuento / es de información"; "este es de verdad / este es de juguete". Esto sucede solo con el 13\% de las Escuelas X. En Jardín el contraste también es interesante: $56 \%$ en las Escuelas Z y $27 \%$ en las $X$.

Todos los Jardines contaban con bibliotecas dentro de las salas. El contraste de nuestros resultados entre $X$ y $Z$ parece indicar que la mera presencia de esas bibliotecas no necesariamente garantiza un contacto fructífero de los pequeños con los libros si no existe una adecuada intervención del docente que les permita participar de reales prácticas de lectura, aun antes de leer de manera convencional. En cuanto a la primaria, cabe recordar que las Escuelas $\mathrm{X}$ no contaban con bibliotecas de aula en Primer Grado, mientras que las Escuelas Z no solo tenían este recurso sino que además el desarrollo de los diversos proyectos incluía cotidianamente el contacto con una multiplicidad de libros de diferentes géneros.

Lo anteriormente expuesto corrobora la primera de nuestras hipótesis, en la que se consideraba probable que la mayoría de los niños -de ambos contextos de enseñanza- pudiera identificar adecuadamente la enciclopedia como el libro que contiene información sobre las abejas, pero que los de las Escuelas Z lograrían justificar su elección a partir de indicadores vinculados con aspectos del lenguaje escrito y/o de los libros como objetos culturales.

Abordaremos a continuación las conclusiones vinculadas con el segundo interrogante. 
2.- ¿Qué página de la enciclopedia seleccionan inicialmente, qué aspectos toman en consideración para localizar una información específica y cuál es la estabilidad de la elección inicial frente a las intervenciones del investigador? ¿Hay diferencias en las respuestas de los niños en función del nivel de escolaridad y contexto de enseñanza? En caso afirmativo, ¿cuáles son?

Localizar información es una tarea compleja que requiere de búsquedas diversas en función de lo que se necesite encontrar; esta tarea se complejiza aún más frente a la variedad de soportes e información en el mundo actual. Localizar información específica es una práctica de lector habitual que implica una lectura que requiere no leer de "punta a punta" desde un inicio sino que posibilita realizar distintas exploraciones hasta acceder a lo que se busca. Al intentar esa búsqueda el lector debe tomar en cuenta la organización de la información - por temas, por orden alfabético o cronológico- acudir al Índice que permite ubicar de manera más económica la informaron que se busca, focalizar en los títulos y/o subtítulos, coordinar información de imágenes con el texto...

Estas estrategias, que están naturalizadas en los lectores expertos, no son transparentes para los pequeños. Sin embargo, hemos comprobado que muchos alumnos, bajo determinadas condiciones didácticas, logran localizar lo que se les solicita utilizando algunas de esas estrategias al finalizar la sala de 5 y/o el Primer Grado de primaria.

Tal como se consignara en el Capítulo IV, la situación experimental consistía en solicitar la localización de la página de información sobre las abejas y luego el entrevistador hacía una contra sugerencia, en función de la cual los niños podían sostener su decisión inicial o cambiarla. Comentaremos a continuación los datos referentes a los diferentes recorridos que efectuaban los niños entre esa elección y la decisión final.

En la elección inicial, la población se divide prácticamente por la mitad entre los que seleccionan la página de las abejas y los que eligen la de las avispas. Los niños que eligen desde el comienzo la página correcta pertenecen mayoritariamente a las Escuelas $Z$ ( $X=40 \%$ y $Z=60 \%$ ); los que, en cambio, seleccionan la de las avispas se distribuye de manera más pareja entre los diferentes grupos de escuelas: $X=52 \%$ y $Z=48 \%$.

Advertimos un cambio significativo en los resultados a partir del diálogo con el investigador. Los guarismos finales lo reflejan: sólo un $28 \%$ termina eligiendo la página inadecuada y el $72 \%$ restante culmina su búsqueda en la página de las abejas. Es probable que la intervención del investigador solicitando justificaciones y proponiendo contraejemplos para que el niño reflexione tal vez más similares en su espíritu a la modalidad con que trabajan los maestros de las escuelas $Z$ - pueda haber tenido un efecto positivo, incluso en niños acostumbrados a un contexto en el que los docentes validan rápidamente sus respuestas. De este modo, muchos alumnos comenzaron a 
tomar en consideración indicios de los textos o precisiones más sutiles de las imágenes a lo largo de la entrevista.

Hemos podido caracterizar cuatro recorridos posibles transitados entre la elección inicial y la final: los que ingresan por la página de las abejas y culminan en ella $(A B+)$, los que ingresan por esa página y cambian de opinión (AB-), los que ingresan por la página de las avispas y culminan en la de las abejas $(\mathrm{AV}+) \mathrm{y}$, finalmente, los que ingresan por la de las avispas y no cambian de opinión $(A V-)$.

Comentaremos a continuación los aspectos cuantitativos de la distribución de los recorridos en los diferentes niveles y contextos de enseñanza.

Si comparamos las respuestas de los niños de Jardín que culminan en la página correcta $(A B+y$ AV+; Gráfico 7 del Capítulo IV), advertimos que los niños que arriban a esa página en los Jardines $X$ constituyen el $46 \%$ ( $18 \%$ que elige inicialmente la página de abejas y resiste el contraejemplo del investigador y un $28 \%$ que inicialmente había escogido la página de avispas). En los Jardines $Z$ el porcentaje de respuestas que arriban a la página correcta asciende al $78 \%$ (36\% que elige inicialmente la página de abejas y un $42 \%$ que realiza una elección inicial inadecuada). Este análisis cuantitativo arroja una diferencia importante entre las respuestas de las diferentes escuelas.

En Primero Z, un 88\% finaliza en la página adecuada (Gráfico 8, Capítulo IV). De este porcentaje, un $62 \%$ había ingresado por esa página y logra sostener su decisión a lo largo de la entrevista; el $26 \%$ restante consigue tomar en cuenta otros elementos y cambia su opinión. Los porcentajes de Primero $X$ se comportan de manera parecida, con una leve diferencia a favor de los $Z$ : el $42 \%$ elige la página adecuada desde el comienzo y el porcentaje asciende al $73 \%$ después de los intercambios con el investigador. Como puede observarse, no hay diferencias cuantitativas relevantes entre ambos grupos.

Más allá de los aspectos cuantitativos, encontramos algunos contrastes que queremos destacar en las estrategias utilizadas en los recorridos realizados por niños de diferente nivel de escolaridad y tipo de escuela:

- Seleccionan inicialmente la imagen de uno de los insectos y siguen utilizándola como justificación privilegiada.

- Seleccionan inicialmente la imagen de no de los insectos y luego recurren a lo escrito para dar su justificación.

- Recurren desde el comienzo a las escrituras para justificar su elección. 
El contraste que surge del análisis de los datos favorece, en todos los casos, a los niños de las Escuelas Z. Comentaremos los recorridos que culminan en la página de las abejas.

En el grupo que inicia y finaliza su recorrido en la página de abejas $(A B+)$, los alumnos de las Escuelas $Z$ toman en consideración en mayor medida que los $X$ aspectos de las escrituras para justificar su elección.

En Jardín, son 16 los niños que transitaron este recorrido: 11 pertenecen a JZ y 5 a JX. De los primeros, 9 toman en consideración las escrituras -7 de ellos incluso lo hacen espontáneamente en la elección inicial - mientras que de los 5 del otro grupo, 3 se guían exclusivamente por la imagen.

En Primer Grado, 31 alumnos transitaron el mismo recorrido: 20 son de PZ y 11 de PX. Casi todos los niños de PZ (18) apelan a datos de las escrituras, estrategia utilizada solo por 6 niños del PX (Tabla 1; Capítulo IV).

Queremos destacar un hecho significativo del recorrido de los 21 niños de Jardín (13 de JZ y 8 de $\mathrm{JX}$ ) que ingresan por la página incorrecta y culminan en la de abejas (AV+). De los 13 de JZ, ninguno toma en consideración solamente la imagen, es decir, la totalidad apela a la confiabilidad de los datos de la escritura para guiar su elección, hecho que se replica solamente en 2 de los niños de JX, mientras que los 6 restantes se basan solamente en la imagen (Tabla 2; Capítulo IV).

En esta Tesis se dedicó un espacio importante para analizar la información que antecede: qué tipo de datos toman en consideración los niños para justificar su elección final, tanto desde la perspectiva de los elementos gráficos (ilustraciones) como de indicadores textuales. Es en este terreno donde hemos registrado diferencias más notorias entre los dos grupos de escuelas, que avalarían la segunda hipótesis formulada: "Frente a la tarea de localizar una página de la enciclopedia para encontrar información específica sobre las abejas, es posible que haya diferencias en las estrategias utilizadas los niños de Escuelas X y los de las Escuelas Z."

Focalizar en los títulos de los diferentes apartados denota un conocimiento particular de ciertos libros de determinado género, es reconocer que ese objeto no tiene las mismas características que otros, quizás más frecuentados por niños, como son los libros de cuentos. Estos últimos suelen tener un título pero no subtítulos en las diferentes páginas. Reconocer los títulos como modo de búsqueda de información específica implica reconocer la presencia de un formato paratextual que se reitera en cada página, que tiene diversas tipografías y tamaños que indican 
cuestiones diferentes. Las puestas en página conservan semejanzas a la vez que se particularizan. Los títulos en los textos de información se destacan por su ubicación espacial, por la distancia que los separa del resto del texto y por otras marcas gráficas como el tipo de letra diferente y más destacada con negrita o subrayado. Tal como se comentaba anteriormente, todo esto, que está naturalizado para los adultos, no es fácilmente perceptible para un niño pequeño.

Como las páginas tienen ese formato reiterado y la disposición de una página puede ser muy similar a la de la otra, hojear es una estrategia que permite advertir las diferencias reflejadas de manera privilegiada en las imágenes y en los títulos. Todos los niños que han ingresado a la tarea mirando los titulares han hojeado. Estos niños advierten que los títulos son nombres y que ‘abejas' es un nombre entre los nombres.

Este tipo de estrategia fue relevada especialmente en niños pertenecientes a Escuelas Z. Los niños hojeaban el libro y al seleccionar la página focalizaban en el titular e incluso lo cotejaban con el de la página que utilizaba como contra ejemplo el investigador (ABEJAS/AVISPAS).

Cabe destacar que varios niños de las escuelas Z, acudían al Índice para localizar la página solicitada. Ingresar a una enciclopedia por el Índice requiere de un conocimiento particular: saber de su existencia y ubicación en el libro, saber para qué sirve y de qué manera se obtiene información. Los niños que apelaban en primera instancia al Índice para ubicar la página solicitada utilizaban las mismas estrategias que los lectores avezados: sabían dónde encontrarlo en el libro, buscaban la palabra "abejas" en la lista, seguían la línea punteada hasta llegar a los números que indicaban la página. Finalmente, hojeaban el libro hasta llegar a la página de las abejas.

Este accionar pone de manifiesto la inmersión de los niños en un ambiente alfabetizador en el que los libros no solo están a su alcance sino que han sido mediados por sus docentes en prácticas reales y sostenidas de lectura que permitieron a los pequeños apropiarse de características de los textos y de los actos lectores que no hubieran podido descubrir sin ese contexto. Pone de manifiesto, en suma, que aprenden a leer leyendo. 


\section{Bibliografía}

- BAUTIER, E. Y D. BUCHETON (1997) LES PRATIQUES SOCIO-LANGAGIERES DANS LA CLASSE DE FRANCAIS? QUELS ENJEUX? QUELLES DÉMARCHES?. REPRES, 15, 11-26. Traducc.: Perelman, F.

- BLANCHE-BENVENISTE,.C. (1982), "La escritura del lenguaje dominguero", en Ferreiro, E.; Gómez Palacio, M. (comp.), Nuevas perspectivas sobre los procesos de lectura y escritura, México, Siglo XXI.

- BlANCHE-BENVENISTE, C. (1998), Estudios lingüísticos sobre la relación entre oralidad y escritura. Barcelona, Gedisa,

- BORZONE, A.M. y GRAMINIA, S. (1984). "La segmentación fonológica y silábica en niños de pre-escolar y primer grado". Lectura y Vida. Año $5, \mathrm{~N}^{\circ}{ }^{0} 1$, marzo, pp.4-14.

- Borzone, A.M., (1994), Leer y escribir a los 5. Buenos Aires. Aique.

- Borzone A.M.; Rosemberg, C. (2007) "iAgua Fría!”, en Leer y escribir en el jardín Conicet. Buenos Aires.

- Borzone A.M.; Rosemberg, C. (2007) "Tortas Fritas", en Leer y escribir en el jardín Conicet. Buenos Aires.

- Borzone A.M.; Rosemberg, C.; SILva, M.L.; Diuk, B. (2007) "En la casa de Oscarcito 2 y 9". Buenos Aires. Care, CIIPME-CONICET, Arcor.

- BRASLAVSKY, B. (2000) "Las nuevas perspectivas de la alfabetización temprana”, Lectura y vida, Año 21. $\mathrm{N}^{\circ} 4$.

- BRASLAVSKY, B. (2004) ¿Primeras letras o primeras lecturas? Una introducción a la Alfabetización temprana, Buenos Aires, Fondo de Cultura Económica.

- BRUNER, J., (1978), "Learning how to do things with words", en Bruner, J. y Garton, Human growth and development, Oxford, Calredo Press.

- Bus, A.; Van IJZENDOORN, M., (1995) "Mother reading to their 3-years-olds: the role of mother child attachment security in becoming literate", Reading Research Quaterly, 30/4.

- CANO MUÑOZ,S. Y y VERNÓN, S. (2008). "Denominación y uso de consonantes en el proceso inicial de alfabetización". Sección ensayos e investigaciones. Lectura y Vida. Año 29, № 2, junio, pp.32-45.

- CASSANY;D. (2004). "De lo analógico a lo digital. el futuro de la enseñanza de la composición". Lectura y Vida. Año 21, № 42, diciembre, pp.6-15.

- CAstedo Mirta, MolinarI Claudia, ToRres Mirta, SIRO, Ana (2001) Propuestas para el aula - Material para docentes - Lengua - Nivel Inicial y EGB 1. Programa Nacional de Innovaciones Educativas Ministerio de Educación de la Nación, Buenos Aires.

- CAstedo, M.; Siro, A. y MolinaRI, M.C. (1999), Enseñar a leer y aprender a leer. Buenos Aires. Ediciones Novedades Educativas.

- CASTEDO, M.; MolinARI, M.C. y otros (2008). "La lectura en la alfabetización inicial”, La Plata, Provincia de Buenos Aires, DGCyE.

- Castedo, M.; Molinari, C.; TorRes, M. y SiRo, A. (2001). "Propuestas para el aula. Material para docentes. Serie I. Lengua Nivel Inicial y Primer ciclo". Buenos Aires, Programa Nacional de Innovaciones Educativas - Ministerio de Educación de la Nación. 
- CAstedo, M. (2010), “Voces sobre la alfabetización inicial en América Latina, 1980-2010”. Revista Lectura y Vida, Año 31, $\mathrm{n}^{\circ}$ 4, 35-68.

- CAstedo, M.y equipo (2009), Prácticas del Lenguaje en contexto de estudio. La diversidad en los animales. $1^{\circ} \mathrm{y} 2^{\circ}$. Material para el docente. Provincia de Buenos Aires. En:http://servicios2.abc.gov.ar/lainstitucion/sistemaeducativo/educprimaria/practicasdellenguaje/defa ult.cfm

- CAstedo, M.; ToRres, M. (2012) “Un panorama de las teorías de la alfabetización en América Latina durante las últimas décadas (1980-2010)", en Historia de la lectura en la Argentina. Cucuzza, H.R. Buenos Aires. Ed. Calderón.

- CAstorinA, J.A. y otros, (1997), Psicología Genética. Aspectos metodológicos e implicancias pedagógicas, Buenos Aires. Miño y Dávila.

- CAzDEn, C., (1982), "La lengua escrita en contextos escolares", en Ferreiro, E.; Gómez Palacio, M. (comp.), Nuevas perspectivas sobre los procesos de lectura y escritura, México, Siglo XXI.

- ChALL, J.; JACOBS, V., (1990), The reading crisis. Why poor children fall behind. Cambridge, Massachussets: Harvard University Press.

- CutTER, M.E.; KUPERMAN, C. (coord.) (2011), "Lengua. Material para docentes. Primer y Segundo Ciclo y Directores", Proyecto Escuelas del Bicentenario (IIPE-UNESCO), Buenos Aires. Argentina.

- CHARTIER, A. M., (2001), "La enseñanza de la lectura: un enfoque histórico". En La Infancia y la cultura escrita. México. Siglo XXI.

- ChARTIER, A. M. (2004), Enseñar a leer y escribir. Una aproximación histórica. Fondo de Cultura Económica.

- Chartier, A. M. y Hebrard, J., (1994), Discursos sobre la lectura. España, Gedisa

- CLAY, M., (1991), Becoming literate. Portsmouth, NH: Heinemann.

- Diseño curricular para La Educación Inicial y Primaria (2000) Buenos Aires: GCBA. Secretaría de Educación. Dirección General de Planeamiento, Dirección de Currícula.

- Diseño Curricular para la Educación Primaria, Primer Ciclo, (2008), D.G.C. y E. de la Provincia de Buenos Aires. La Plata.

- Dubois, M.E. (1991), El proceso de lectura: de la teoría a la práctica. Buenos Aires, Aique.

- FERREIRO, E. (1986). Procesos de alfabetización. La alfabetización en proceso. Buenos Aires: Centro Editor de América Latina.

- FERREIRO, E. (ed.) (1989) Los hijos del analfabetismo. Propuestas para la alfabetización escolar en América Latina. México, Siglo XXI Editores.

- FERREIRO, E. (1990), "La reconstrucción de lo oral en el proceso de adquisición de la escritura", II Coloquio Mauricio Swadesh, Instituto de Investigaciones Antropológicas. UNAM, octubre.

- FERREIRO, E. , "Desarrollo de la alfabetización: psicogénesis" en Y. Goodman (comp.) (1991) Los niños construyen su lectoescritura, Aique, Buenos Aires.

- FerReIRo, E. (1997), Alfabetización. Teoría y práctica, México, Siglo XXI Editores.

- FERREIRO, E. (1999), Cultura escrita y educación. Conversaciones con Emilia Ferreiro. México. FCE.

- FERREIRO, E. (1999), Vigencia de Jean Piaget, México, Siglo XXI.

- FERREIRO, E. (2003), Los niños piensan sobre la escritura, México, Siglo XXI Editores.

- FERreiro, E., (2007), Alfabetización de niños y adultos. Textos Escogidos, México, Paideia Latinoamericana. 
- FerReiro, E. y Teberosky, A. (1979), Los sistemas de escritura en el desarrollo del niño. México, Siglo $\mathrm{XXI}$.

- FERREIRO, E. y Gómez PALACIO, M. (eds.) (1982), Nuevas perspectivas sobre los procesos de lectura y escritura, México, Siglo XXI Editores.

- FERREIRO, E. y Gómez PALACIO, M. (1982), "Análisis de las perturbaciones en el proceso de aprendizaje escolar de la lectura y la escritura". Fascículo 3. México.

- FerReiro, E.; Gómez Palacio, M. (1979), El niño preescolar y su comprensión del sistema de escritura. Monterrey, SEP.

- FERREIRO, E.; PonTECORVo, C. y otros, (1996), Caperucita Roja aprende a escribir. Estudios lingüísticos comparativos en tres lenguas, Barcelona, Gedisa.

- GoOdMAN, K. (1982), "El proceso de escritura: consideraciones a través de las lenguas y del desarrollo". En: FERREIRO, E.; GÓmEZ PALACIO, M. (comp.), Nuevas perspectivas sobre los procesos de lectura y escritura, México, Siglo XXI.

- Goodman, K., (1997), "Learning about a Psicholinguistic Process by analizing oral reading". Harvard Educational Review, 47.

- Goodman, Y. (1990), "Descubriendo la invención de la lengua escrita en los niños”. En: Goodman, Y. (comp.), Los niños construyen su lecto-escritura. Buenos Aires, Aique.

- GoOdMAN, Y. (1982), "El desarrollo de la escritura en niños muy pequeños”. En: FERREIRO, E.; GómEZ PALACIO, M. (comp.), Nuevas perspectivas sobre los procesos de lectura y escritura, México, Siglo XXI.

- GoOdmAn, Y., (1992), "Las raíces de la alfabetización”. Barcelona, Infancia y aprendizaje, 58.

- HARSTE, J.; BuRKe, C. (1982), "Predictibilidad: un universal en lecto-escritura”. En: FerReIRo, E.; GómeZ PALACIO, M. (comp.), Nuevas perspectivas sobre los procesos de lectura y escritura, México, Siglo $X X I$.

- IRWIN, C., (1960) "Infant speech: Effect of sistematic reading of stories". Journal of speech and hearing research, 3.

- KaUfmAn, A. (1988), La lecto-escritura y la escuela, Buenos Aires, Santillana.

- Kaufman, A., M. Castedo, L. Teruggi y C. Molinari (1989), Alfabetización de niños: construcción e intercambio, Buenos Aires, Aique.

- Kaufman, A. (coord), (2007), Leer y escribir: el día a día en las aulas. Buenos Aires, Aique.

- KAUFMAN, A., M.E. RODRÍGUEZ, (1993) La escuela y los textos. Santillana.

- LAHIRE, B. (2004), Sociología de la lectura. Barcelona. Gedisa.

- LERNER, D., (2001), Leer y escribir en la escuela: lo real, lo posible y lo necesario. México, Fondo de Cultura Económica.

- LeRnER, D. (1996), "La enseñanza y el aprendizaje escolar. Alegato contra una falsa oposición”. En, Contribuciones para replantear el debate. Buenos Aires. Paidós, pp. 69-118.

- Lerner, D., H. LeVy, S. Lobello; L. Lotito, E. Lorente y N. NatAli (1996), Actualización Curricular en LENGUA. Documento de trabajo $N^{\circ} 2$, Buenos Aires, Dirección de Curricular, Secretaría de Educación de la Ciudad de Buenos Aires.

- NemiRovSKY, M., (1999), Sobre la enseñanza del lenguaje escrito... y temas aledaños. Buenos Aires, Paidós. 
- NiNIO, A., J. BRUNER (1978), "The achievement and the antecedents of labeling". Journal of Child Language, 5.

- Perelman, F. (2011), "Las lecturas exploratorias como objetos de enseñanza". En: Las TIC en la escuela nuevas herramientas para viejos y nuevos problemas. España. Océano Travesía.

- Piaget, J.; InHeldeR, B.; GaRcía, R.; VoneChe, J. (1981). Epistemología genética y equilibración, España, Ed. Fundamentos.

- ScARDAmaliA, M.; Bereiter, C., (1992), "Dos modelos explicativos de los procesos de composición escrita". Barcelona, Infancia y aprendizaje, 58.

- Smith, F., (1971), Comprender la lectura. México. Trillas.

- SNOW, C., (1983), "Literacy and language: relationships during the preschool years", Harvard Educational Review, 53, 2.

- SolÉ, I; TEBEROSkY, A. (1990), "La enseñanza y el aprendizaje de la alfabetización; una perspectiva psicológica". En, ColL, C.; PALACIOS, J. y MARChESE, A. (comp.), Desarrollo psicológico y educación, Madrid, Alianza.

- SOLÉ, I. (1996), Estrategias de lectura. Barcelona. ICE.

- SPREgelBuRD, R. (2002), “¿Qué se puede leer en la escuela? El control estatal del texto escolar (18801916)". En: CucuzzA, H. y otros: Para una historia de la enseñanza de la lectura y la escritura en Argentina. Bs. As. Miño y Dávila.

- TEAlE, W.; Sulzby, E., (1986), Emergent Literacy. New Yersey, Ablex.

- TEBerosky, A., (1998), "Enseñar a escribir en la edad de la escritura”. España. Textos. Didáctica de la Lengua y la Literatura, 17.

- Teberosky, A., (1992), Aprendiendo a escribir. Barcelona, Horsori.

- Teberosky, A. (1991), "La lengua que escriben los niños pequeños". En: Goodman, Yetta (comp.) Los niños construyen su lecto-escritura. Un enfoque piagetiano. Buenos Aires, Aique.

- Teberosky, A., (1990) “El lenguaje escrito y la alfabetización”, Lectura y Vida. Año 11. № 3, p. 5-15.

- TeBerosky, A.; Colomer, T., (2003), Propuesta constructivista para aprender a leer y escribir". España, Vicens Vives.

- TeBerosky, A. ; TolCHINSKY, L. (1995) Más allá de la alfabetización. Buenos aires, Santillana.

- TOLCHINSKY L., (1993), Aprendizaje del Lenguaje escrito, España, Universidad Pedagógica Nacional y editorial Anthropos.

- TolChINSKY, L., SANDBANK, A., (1990), "Producción y reflexión textual: Procesos evolutivos e influencias educativas", Lectura y Vida, Año 11, № 4, pp. 11-23.

- TORRES, M. (2008), "Leer para aprender historia. El lugar del texto en la reconstrucción de un contenido", Lectura y Vida, Año 29, № 1, pp. 20 -29.

- Vernon, S., (2004), "El constructivismo y otros enfoques didácticos". En: Pellicer, A.; Vernon, S., Aprender y enseñar la lengua escrita en el aula, México, SM.

- VERNON, S., (2001), "Modelos pedagógicos en la enseñanza inicial de la lengua escrita". Psicología y Sociedad, Número especial,

- Wainerman, C.; HerediA, M., (1999) Cien años en los libros de lectura de la escuela primaria, Buenos Aires. Ed. de Belgrano.

- WEISZ, T. (2000), O dialogo o ensino e a aprendizagem, São Paulo, Ática. 


$$
\text { ANEXOS }
$$





\section{ANEXO I- Capítulo II}

\section{Materiales correspondientes a Salas de 5 años de Jardines $X$}

Se presentan algunas actividades extraídas de los cuadernos. En cada caso se transcriben las consignas explicitadas por la maestra.

\section{Material 1}

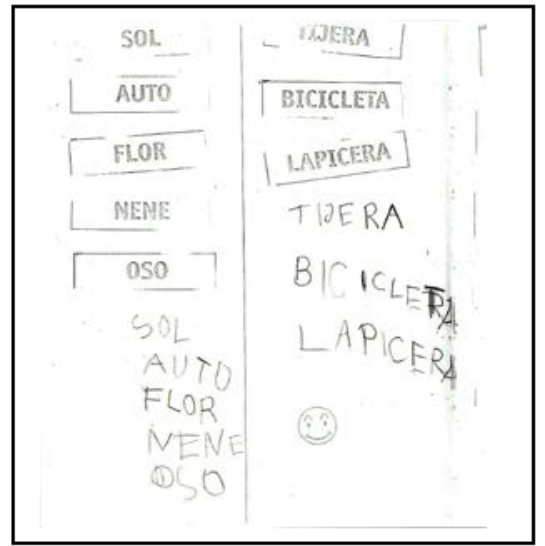

Recorto y pego de un lado palabras largas y del otro palabras cortas y las

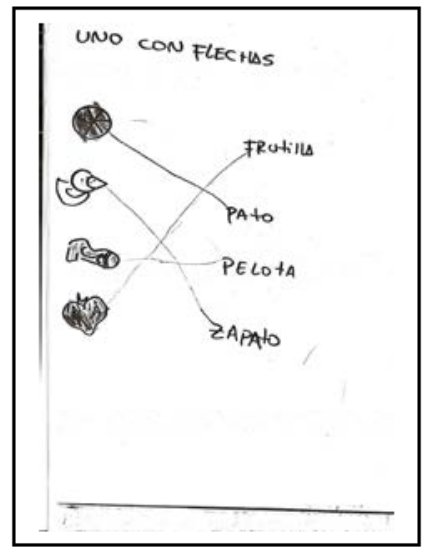

Uno con flechas el dibujo con su palabra.

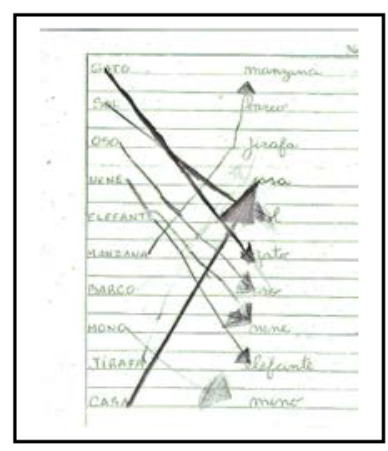

Uno la misma palabra en imprenta y en cursiva.

\section{Material 2}

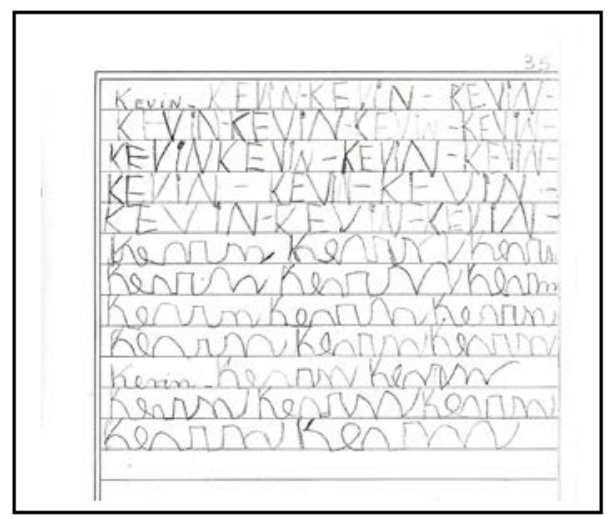

Sobre los renglones escribo $\mathrm{mi}$ nombre en imprenta y en cursiva. 


\section{Material 3}

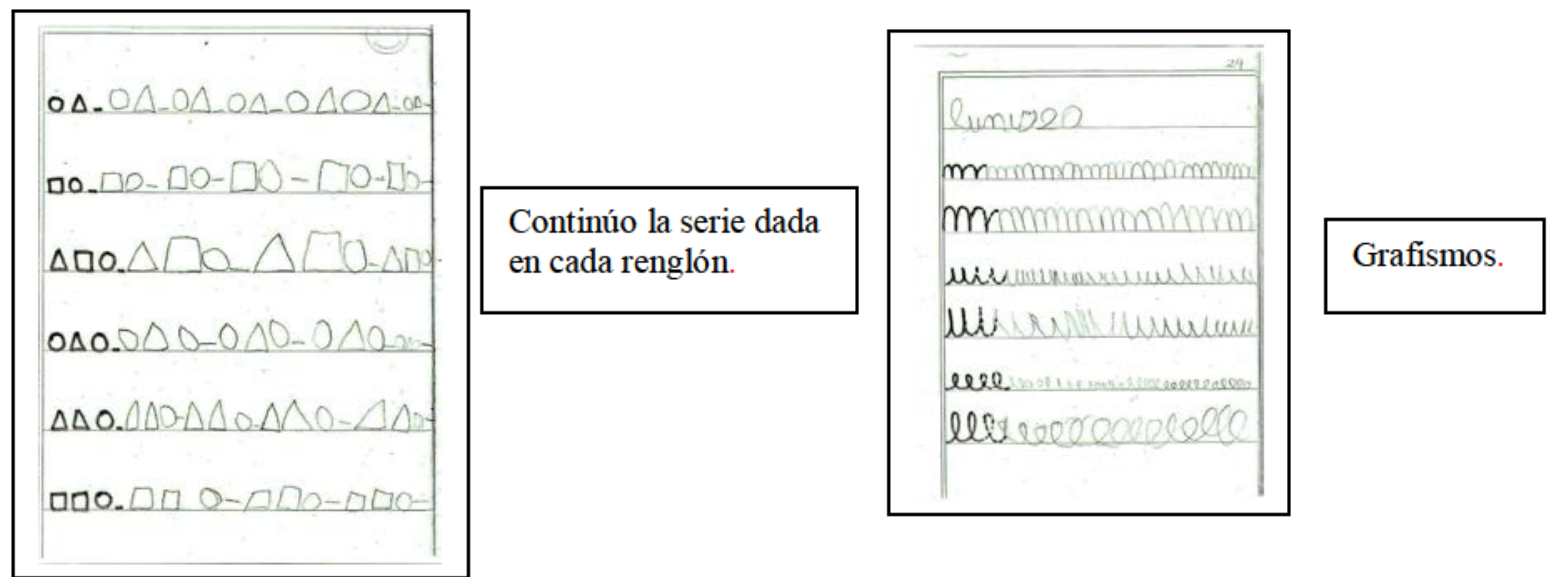

\section{Material 4}

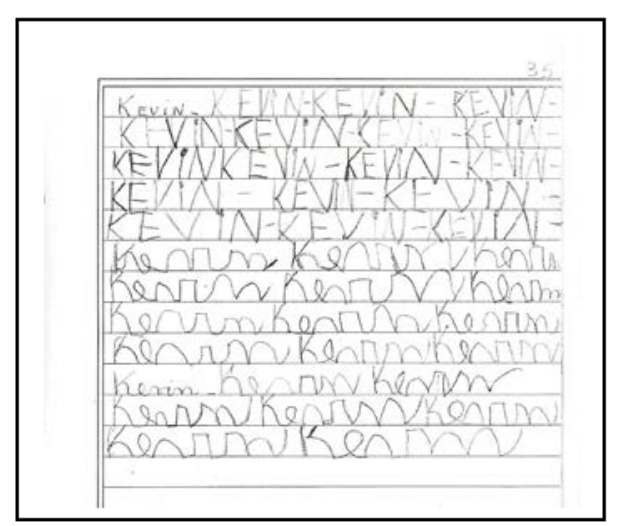

Sobre los renglones escribo mi nombre en imprenta y en cursiva.

\section{Material 5}

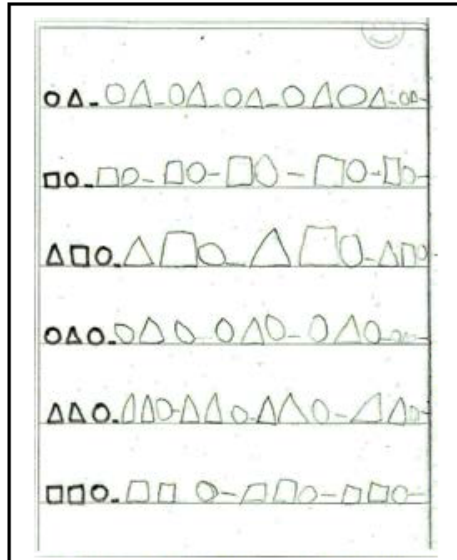

Continúo la serie dada en cada renglón.

Escribo en cursiva la serie dada. 

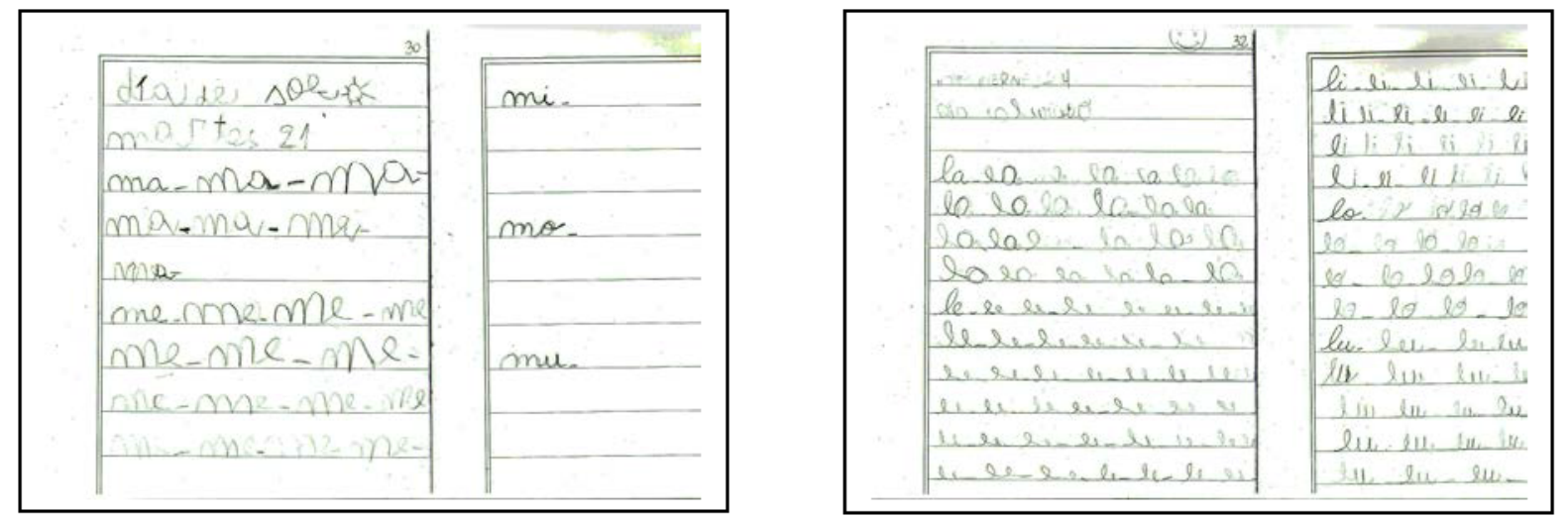

Escribo en cursiva la serie dada.

\section{Material 6}

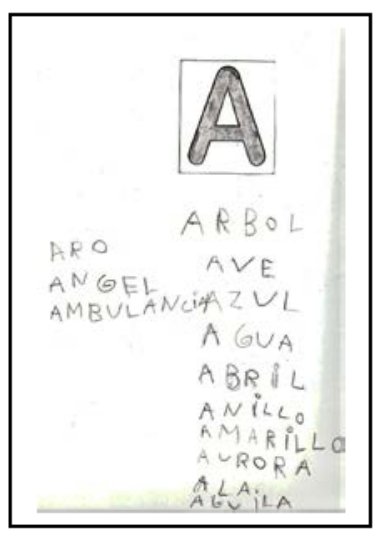

Pienso palabras que empiecen con A y las copio del pizarrón.

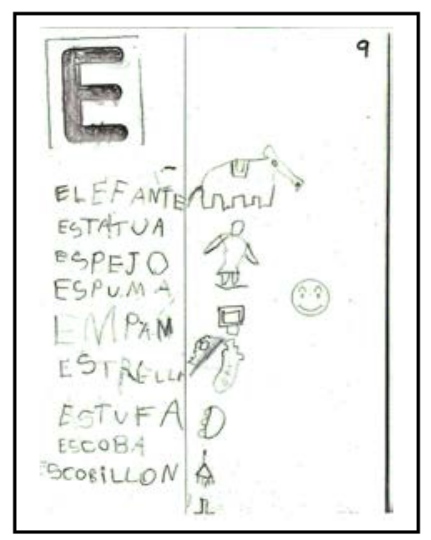

Pienso palabras que empiecen con A, las copio del pizarrón y hago los dibujos de cada palabra.

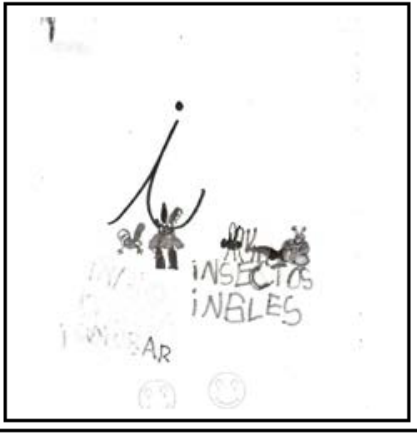

Pienso y copio las palabras que empiecen con I y hago los dibujos respetando el margen.

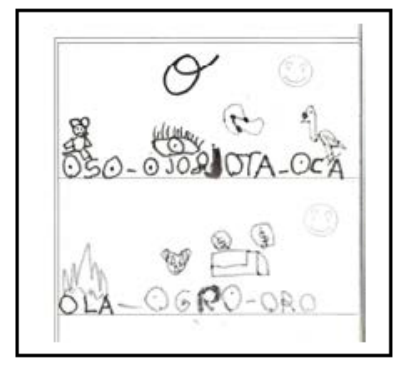

Pienso, copio y escribo palabras que empiecen con $\mathrm{O}$, hago los dibujos. 


\section{Material 7}

Índice -escrito por la maestra- de actividades realizadas que se encontraba al final del cuaderno de los niños.

ÍNDICE DE LAS ACTIVIDADES REALIZADAS

3- Carátula: Hacemos un dibujo libre.

4- El abecedario: coloreo las letras

5- Pienso palabras que empiezan con A y las copio del pizarrón.

6- Dibujo cosas que empiezan con A

7- Mi nombre en imprenta y en cursiva.

8- Arriba de la línea escribo números y abajo letras.

9- Pienso palabras que empiezan con E, las copio del pizarrón y hago los dibujos de cada palabra.

10-Recorto y pego de un lado palabras largas y del otro palabras cortas y las escribo.

11- Recorto, armo y pego la serie numérica de 1 a 5 copio las palabras y dibujo tantas cosas como indica el $\mathrm{N}^{\circ}$

12 -Recorto, armo y pego la serie numérica de 6 a 10 copio las palabras y dibujo tantas cosas como indica el $\mathrm{N}^{\mathrm{O}}$

13- Secuencia: Dibujo que hago en casa cuando me levanto, cuando estoy en el Jardin, cuando vuelvo a casa y antes de ir a dormir.

14- Dibujo tantos elementos como me indica el número.

15- Dibujo solo en el margen.

16-Pienso y copio palabras que empiezan con I y hago los dibujos respetando el margen .

17-Visitamos la granja Los Cipreses, dibujo lo que mas me gustó.

18- Dibujo el principio, parte del desarrollo y el final del cuento "Historia de Ratita".

19-Pienso, copio y escribo palabras que empiezan con $\mathrm{O}$, hago los dibujos. 20- Escribo mi nombre y apellido en cursiva.

21 y 22 - Dictado de cantidades representadas por dibujos (sobre el renglón).

23- Escribo sobre el renglón 4 palabras y hago el dibujito.

24- Pienso, copio y escribo palabras que empiezan con $U$, hago los dibujos.

25-Dictado de una serie de figuras geométricas.

26- Continuio la serie dada en cada renglón.

27- Visitamos la escuela primaria. Dibujo lo que me gusto más.

28- Busco, recorto, armo y pego mi nombre.

29- Grafismos.

30 y 31 - Escribo en cursiva la seria dada. MA, ME, MI, MO, MU.

32 y 33- Escribo en cursiva la seria dada. LA , LE , LI, LO, LU.

34- Pinto los objetos que me protegen del sol.

35 - Sobre los renglones escribo mi nombre en imprenta y en cursiva.

36- Uno la misma palabra en imprenta y en cursiva

37- Una despedida MUY ESPECIAL. 


\section{ANEXO I- Capítulo II}

\section{Materiales correspondientes a Salas de 5 año de Jardines $Z$}

Se presentan algunas actividades extraídas de los cuadernos y de proyectos realizados.

\section{Material 8}

Situaciones de escritura a partir de la lectura de fuentes seguras información.

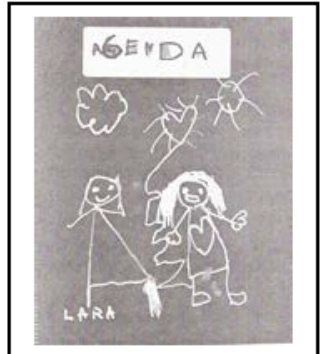

Tapa y hoja correspondiente al mes de diciembre de una de las agendas telefónicas producidas por un alumno.

Día 1 Cumple de Camila. Fiesta en el Jardín.

Día 11 vamos a jugar al carnaval Día 15 fiesta de despedida

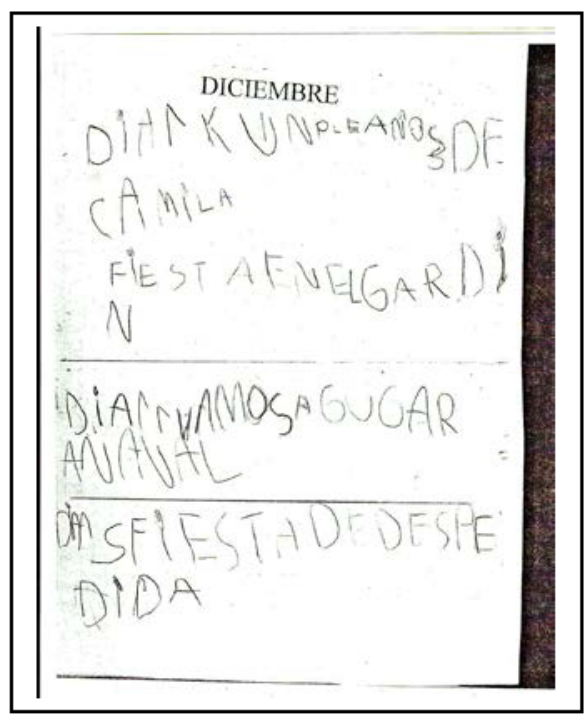

\section{Material 9}

Situaciones de escritura a partir de lo leído.

Tapa y hoja interior del libro producido a partir de la visita de la ilustradora Mónica Weis.
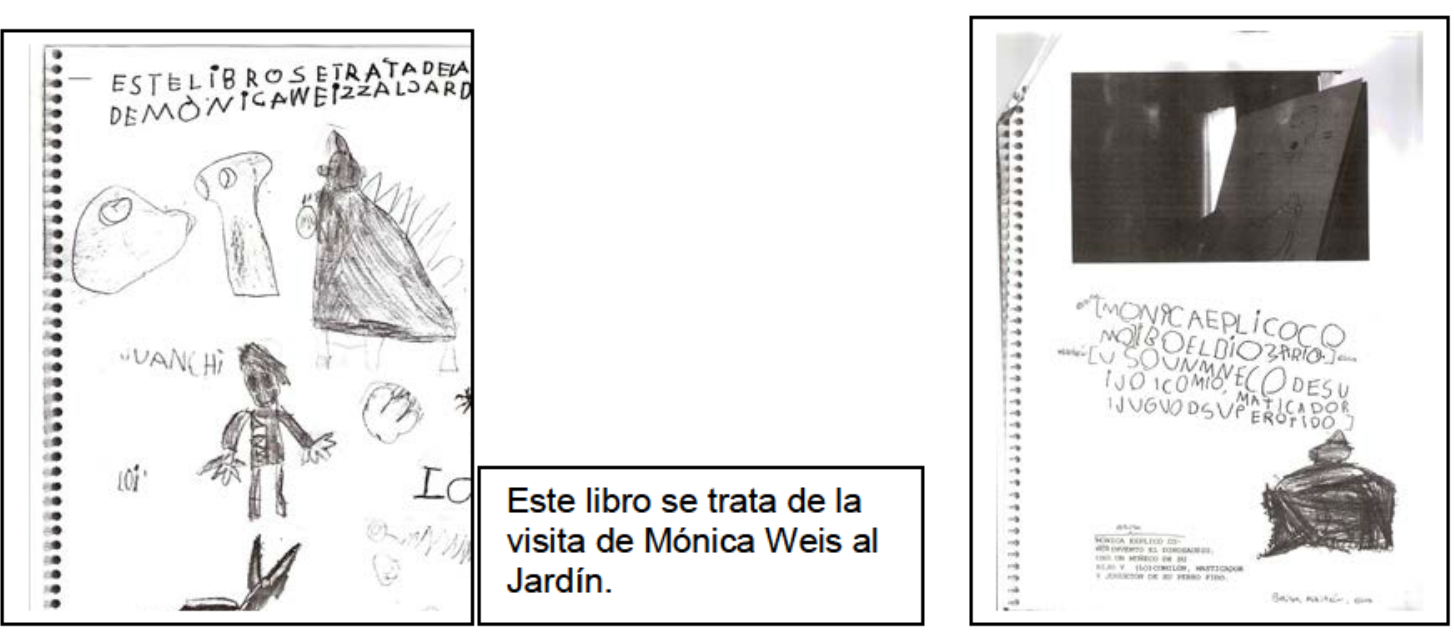

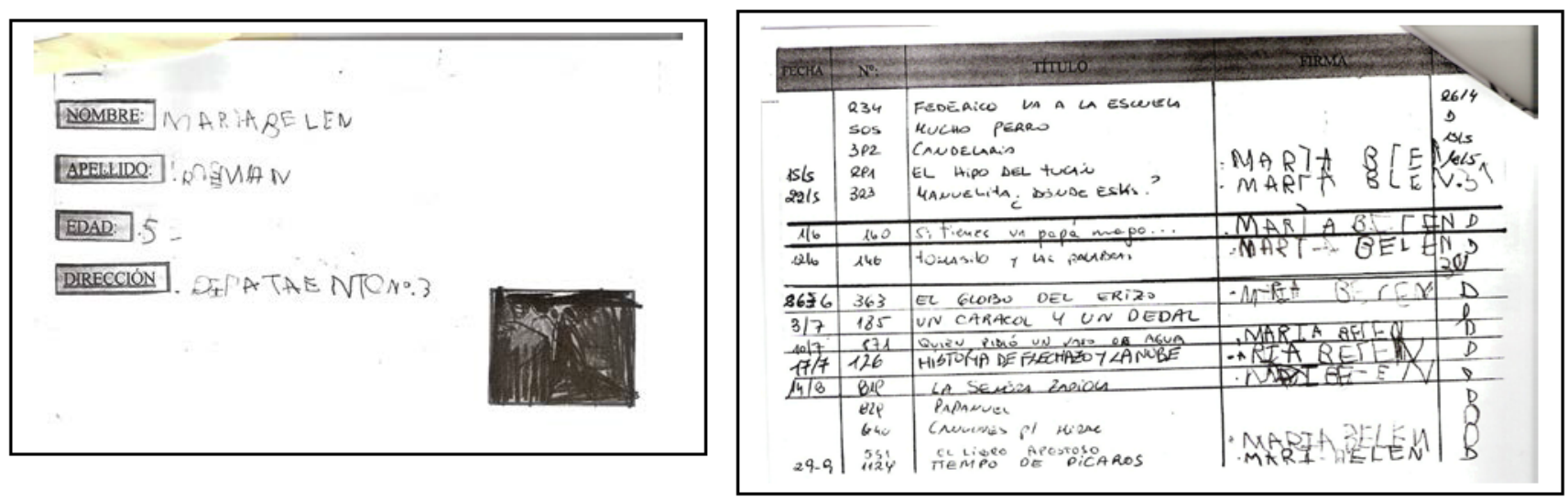

\section{Material 10}

\section{Escrituras en pequeños grupos}

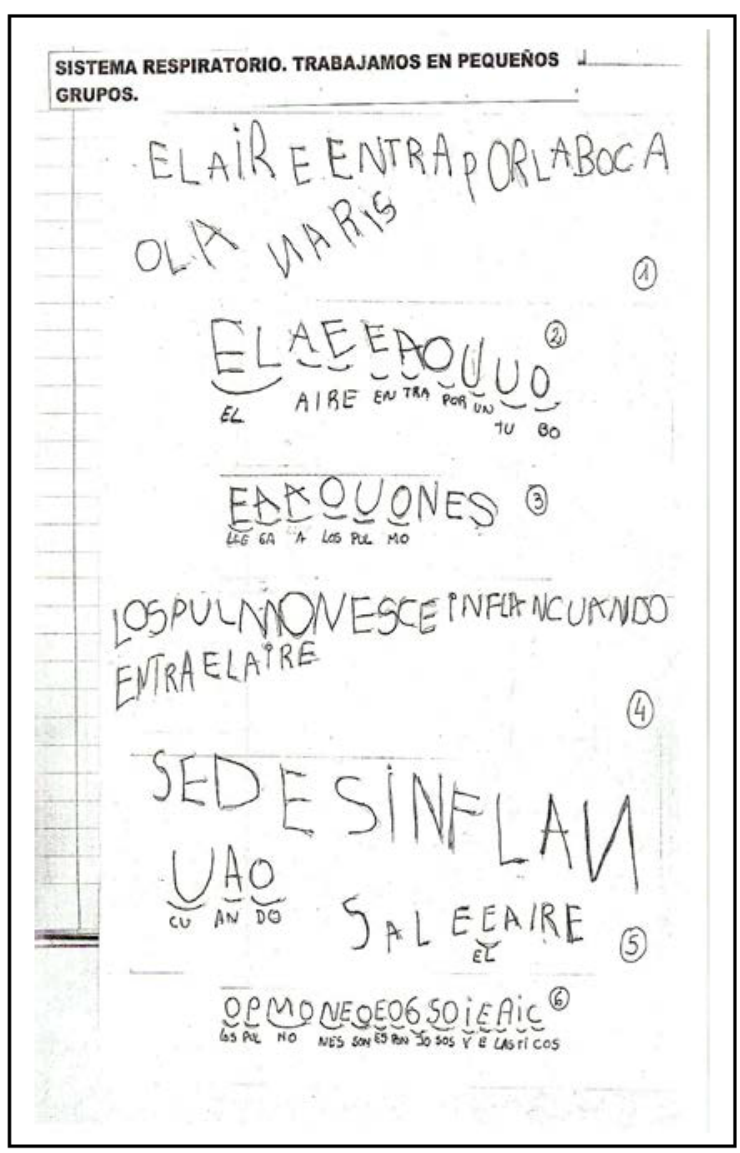

\section{Escrituras en parejas}

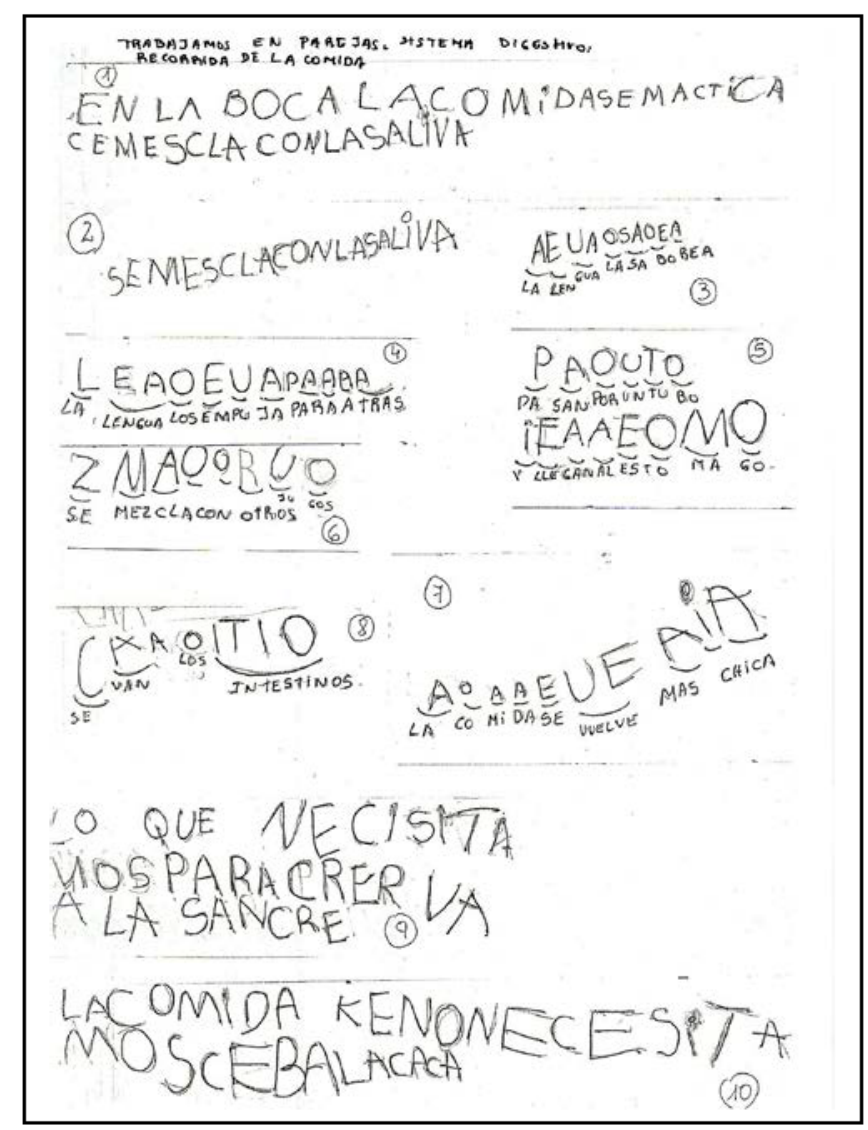




\section{ANEXO I- Capítulo II}

\section{Materiales correspondientes a PRIMER GRADO X}

\section{Material 11}

La maestra entrega a los niños una copia con dibujos que deberán recortar y pegar, para luego escribir al lado el nombre del objeto dibujado. Define como objetivo de la clase " fijar la be larga y la ve corta; que la distingan y las puedan escribir bien"

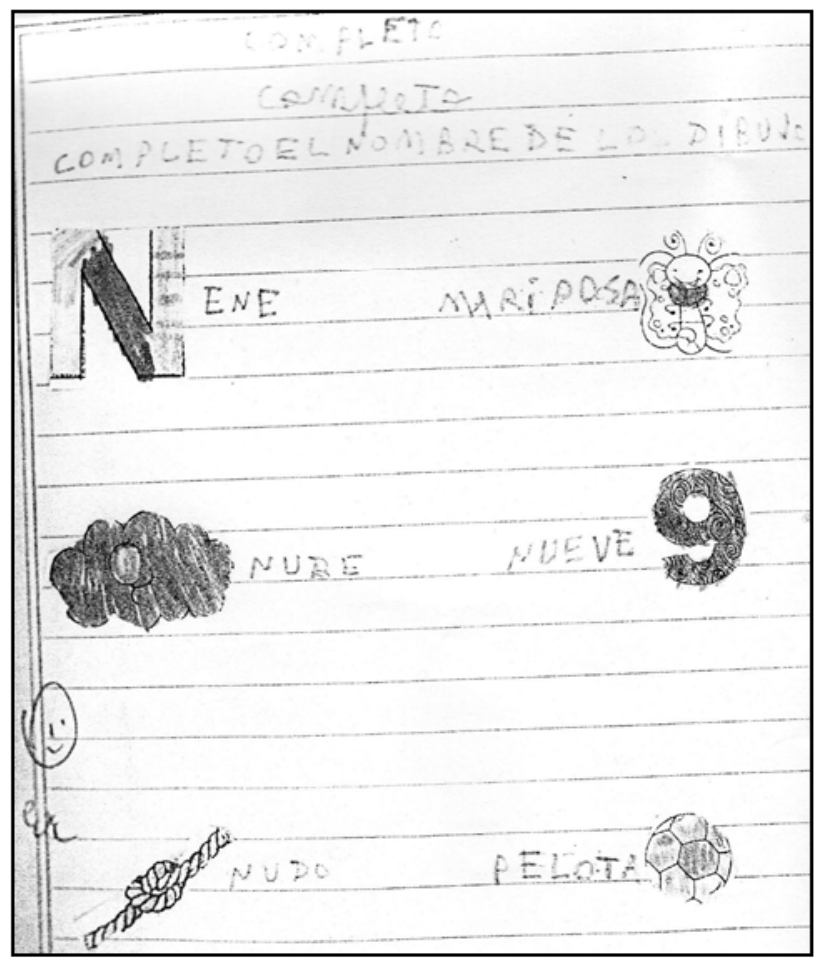

\section{Material 12}

Llenar la letra con papel.

Copiar las palabras del pizarrón.

Dibujar las palabras.

Docente: Yo les doy la copia con dibujitos. Vamos a ir diciendo despacito los nombres de cada cosa dibujada y después ponemos los nombres a ver que palabras hay dibujadas. ¿ dibujo hay?

Alumno: Nube... esto es una nube.... D: La decimos todos juntos: nu- be, nu- be. ¿Va con 'b' o 'v'?

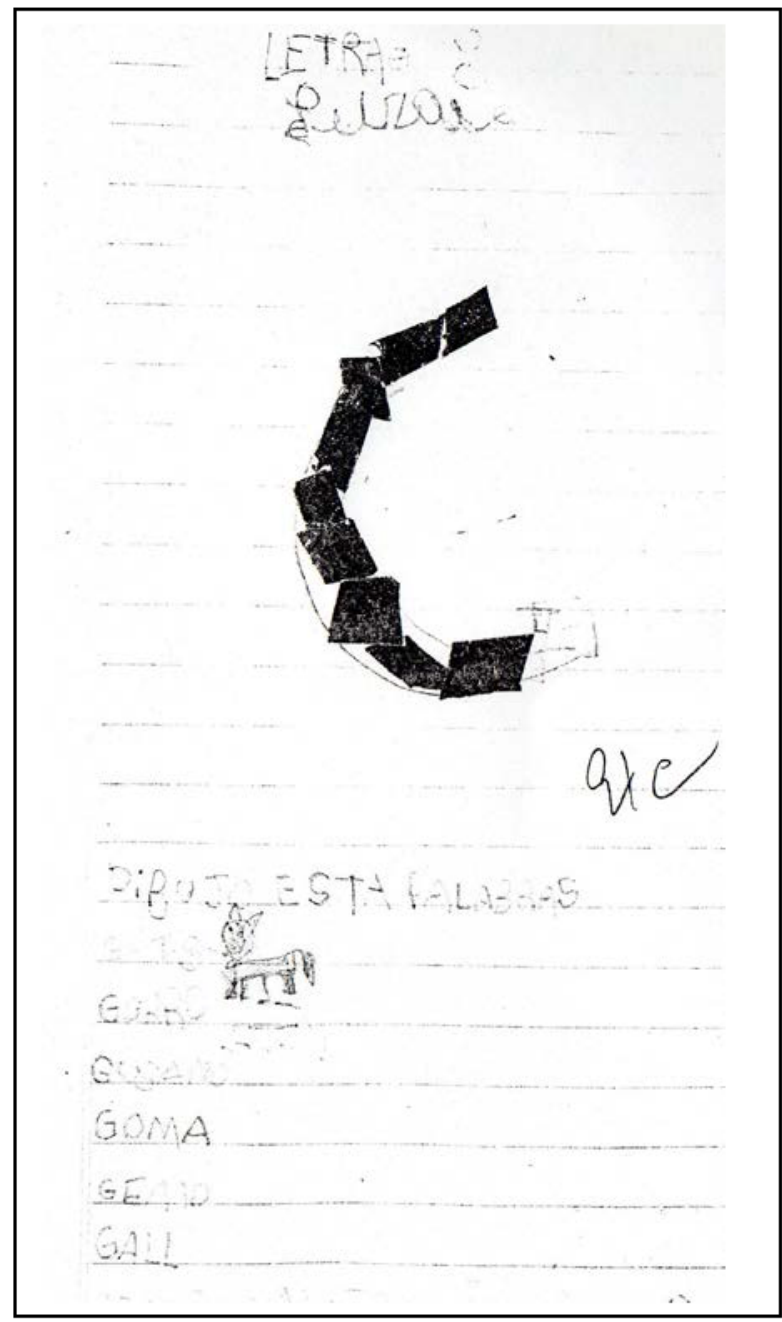




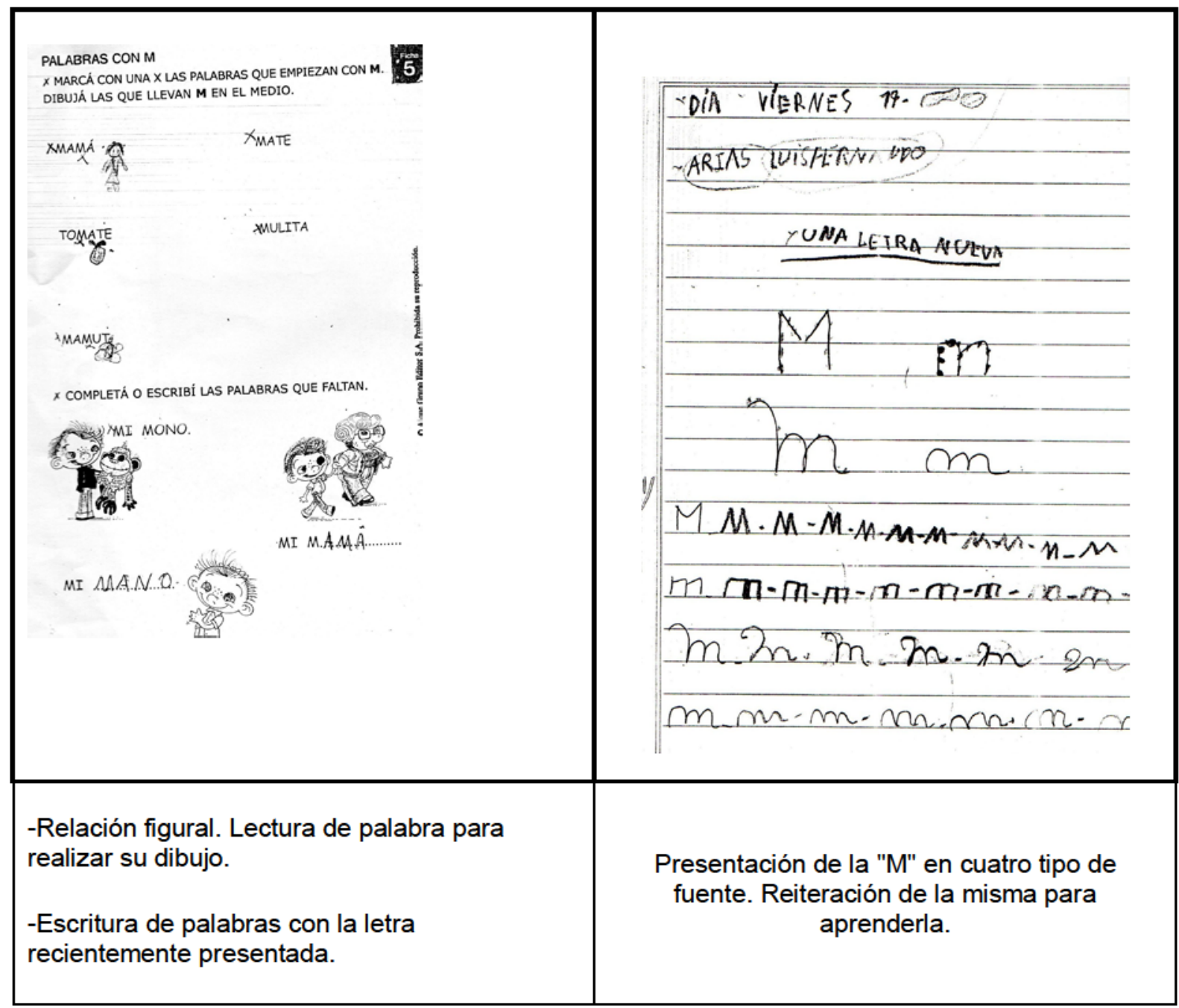




\section{ANEXO I- Capítulo II}

Materiales correspondientes a PRIMER GRADO Z

Material 15

Escritura a través del maestro de una recomendación colectiva acerca del cuento leído a través del maestro: "Pedro de Urdemales y el árbol de plata". ED. Colihue.

Primera versión

ESTE CUENTO DE GUSTAVO ROLDAN ESGORAQ, ESTA BUENÍSIMO LA HISTORIA DE PEDRO URDEMALES Y EL ARBOL DE PLATA, ESTA

BUENISIMO, LO LEIMOS AUCHAS VECES Y ES GRACIOSA.

PEDRO LE MINTIO TUVO UNA IDEA,

PARA VENDER UN ARBOL DE MONEDAS DE PLATA

Y UN CABALLERO PASO POR LA CALLE

SI QUIEREN SABER LO QUE PASO

LEAN ESTE GUSTO CUENTO QUE LES VA A GUSTAR

Segunda versión

TE RECOMENDAMOS EL GUENTODE

LA HISTORIA DE PEDRO UREDEMALES Y EL ARBOL

DE PLATA, LO LEIMOS MUCHAS VECES PORQUE

ESTARE-DIVERTIDO.NOS GUSTO MUCHO.

A PEDRO SE LE OCURRIO UNA IDEA

PARA TENER MAS PLATA, SI QUIEREN SABER LO

QUE PASO CON PEDRO, LEAN ESTE CUENTO,

GUSTAVO ROLQANESELAUTOR QE LAHISTORIA

QUE ESTA EN $1^{\circ}$ A. QUE LES VAA GUSTAR. ESTA COPADO.

GUSTAVO ROLDAN ES EL AUTOR DE LA HISTORIA.

Versión Final

TE RECOMEDAMOS LA HISTORIA

DE PEDRO URDEMALES Y EL

ARBOL DE PLATA, LO LEIMOS

MUCHAS VECES PORQUE NOS

GUSTO MUCHO.

A PEDRO SE LE OCURRIO UNA

IDEA PARA TENER MAS PLATA,

SI QUIEREN SABER LO QUE

PASO CON PEDRO, LEAN ESTE

CUENTO, QUE ESTA EN $1^{\circ} \mathrm{A}$.

ESTA COPADO.

GUSTAVO ROLDAN ES EL AUTOR

DE LA HISTORIA. 


\section{Material 16}

Escritura a través del maestro del resumen de un capítulo de una novela leída.

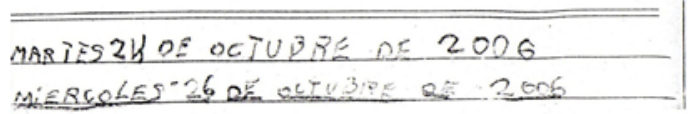

CON CARO.DE ENOENOOYLO DETO

EN PENITENCIA POS MUKAOS DIA

antike

\section{PRODUCCIÓN COLECTIVA DEL CAPÍTULO 10 DE PINOCHO}

- Vino el padRe a buscarlo a salvarlo por Que gritó fuertísimo PINOCHO; POR QUE NO SABİA QUIEN ERA ESE HOMBRE FEO

- El MUNEECO FEo Lo DESTROZÓ POR QUE ENTRÓ AL TEATRO DE TíteRES Y SE ENCONTRÓ CON SUS AMIGOS.

- ESE HOMBRE FUE BUENO Y NO MATÓ A NADIE POR QUE ERA AMIGO DE PINOCHO Y QUERIA ASUSTARLO.

LO ESCONDIERON A PINOCHO LOS HERMANOS DE MADERA DE PINOCHO POR QUE LO CONOCIAN Y SABÍAN QUE ERA BUENO Y LLAMARON AL PAPA PARA Que Lo bUSCARA DESPUÉs

A PINOCHO LO QUEMARON Y SE MURIÓ Y SE HICIERON RICOS CONTANDO ESA HISTORIA PERO PINOCHO SE DESPERTÓ POR QUE SOÑABA.

- El PADRE PEgó A PINOCHO POR QUE VENDió EL LibRo y NO IR A LA escuela y ir al teatro.

- LOS HERMANOS DE PINOCHO LO CONOCÍAN Y EL hOMBRE LOS EMPEZÓ a CORRER POR QUE PINOCHO SE FUE CON SUS AMIGOS A LA ESCUELA Y LO DEJARON SOLO AL HOMBRE MALO.
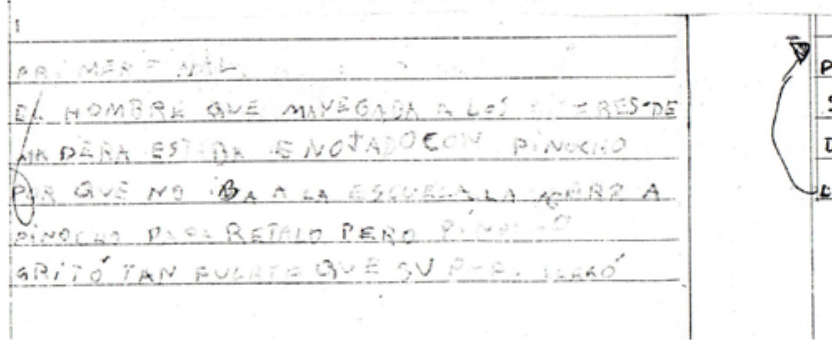

DADO CON CÓMO

TPARAJAST

$A s i$

MER SA PELAV ESI

ENTAYLO

DES PUES

A+ $\cos V_{A}+5 \mathrm{~A}-\mathrm{A}$.

YR LA CARNG

ENTAR

- 0000

7 PRIMERO SE PELTN Y DESPUE

SE SACA EL CORASONY DESPUE SE COR: DESPUES SE METE A LA LI CUADORA CON LíUADO MANSANA AUGA

16 AMOS SOBRE ¿CAMOS LIBRO DE COCINA.

\section{Material 17}

Situaciones del cuaderno de clase que registran lo leído a través del maestro.

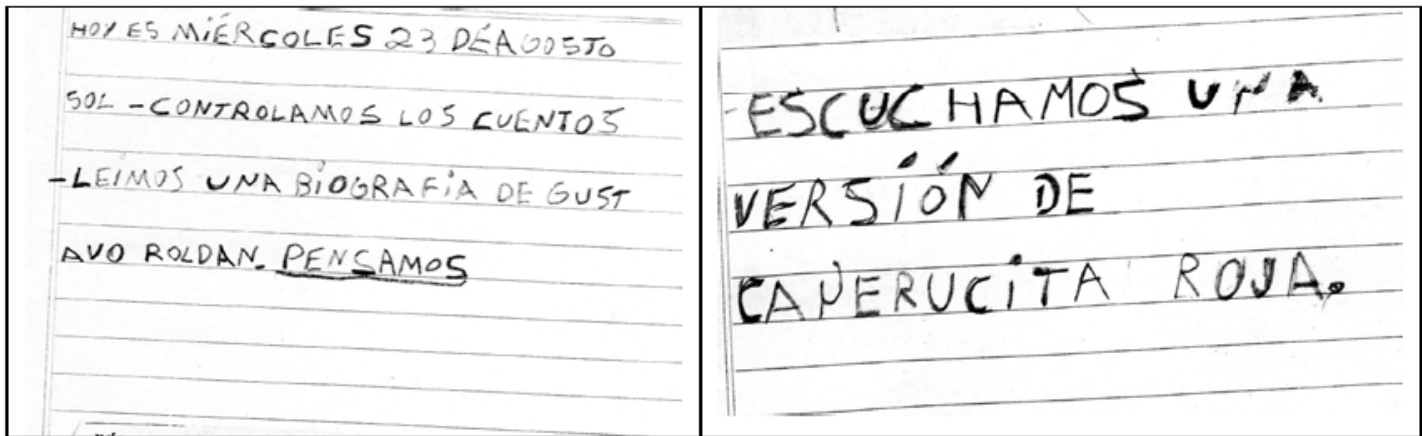

DIA NUEVES TBDE UULIO
MIRAMOS LIBRO DE PIN
$\begin{aligned} & \text { TORES } \text { - VAN GOGH } \\ & \text { - MURILLO } \\ & \text { - REMOIR } \\ & \text {-FRIDA KAHLO } \\ & \text { MIGUE GARAY }\end{aligned}$


Material 18

Situaciones en el cuaderno de clase de escritura a partir de lo leído.

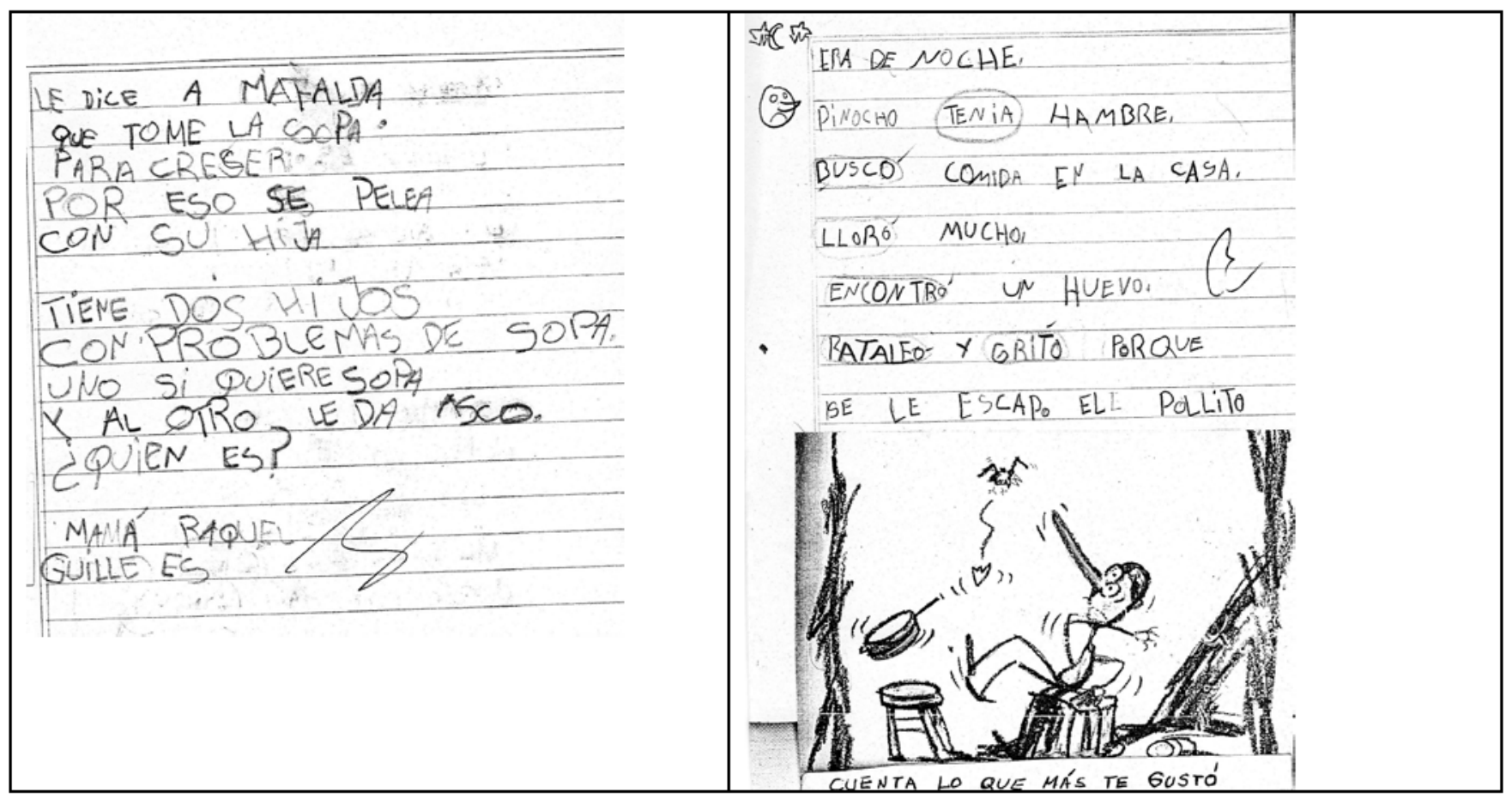

\section{Material 19}

Situaciones en el cuaderno de clase de escritura a partir de lo leído.

Historietas completas de circulación social para leer por sí mismos.

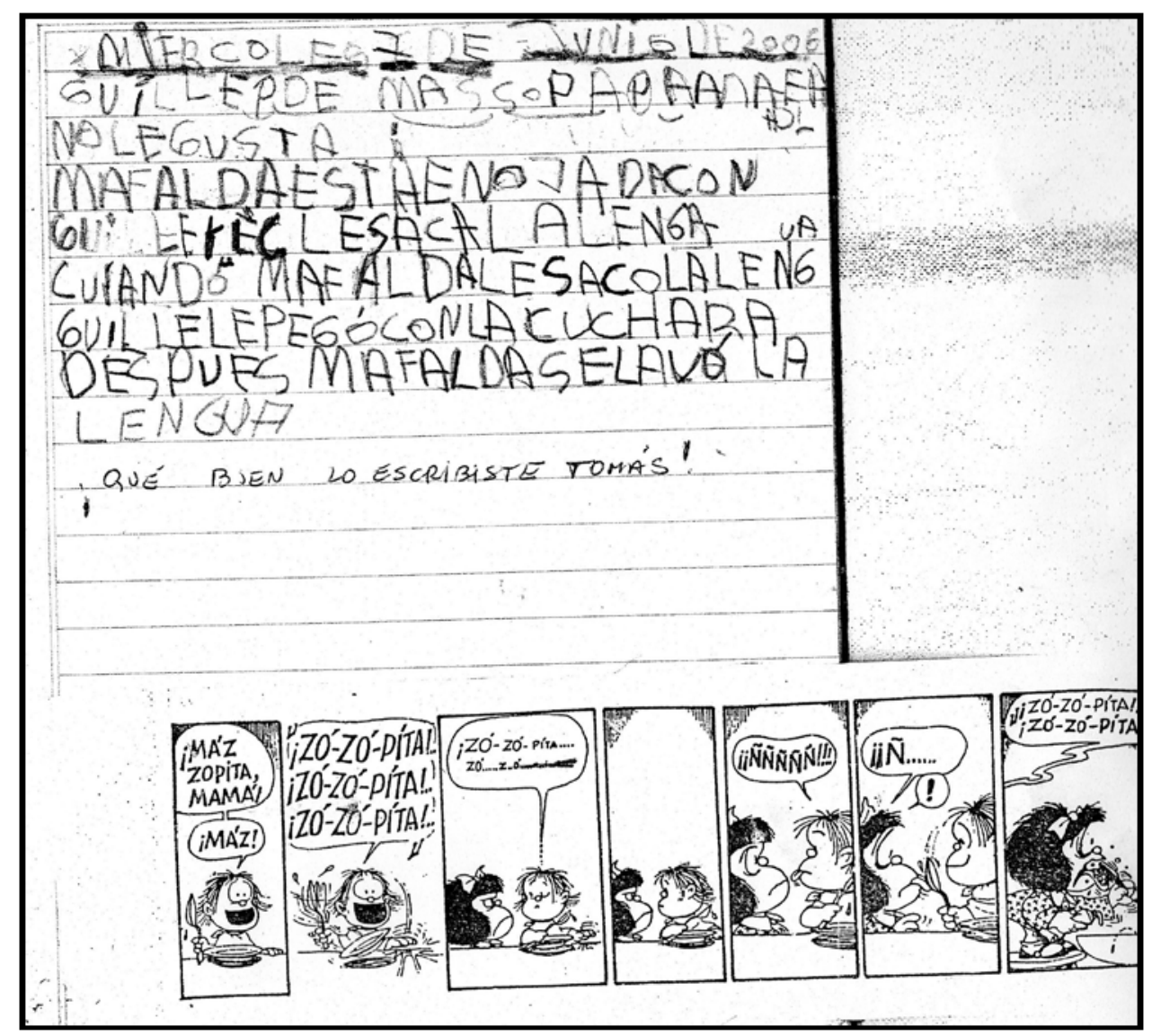





\title{
ANEXO II - Capítulo II
}

\author{
Enciclopedia utilizada \\ El insólito reino de los Insectos \\ Ed. Susaeta
}

La enciclopedia citada se encuentra disponible en la versión impresa de la presente Tesis. 

ANEXO III- Capítulo II

Ejemplos del material utilizado para el registro de la Situación 2
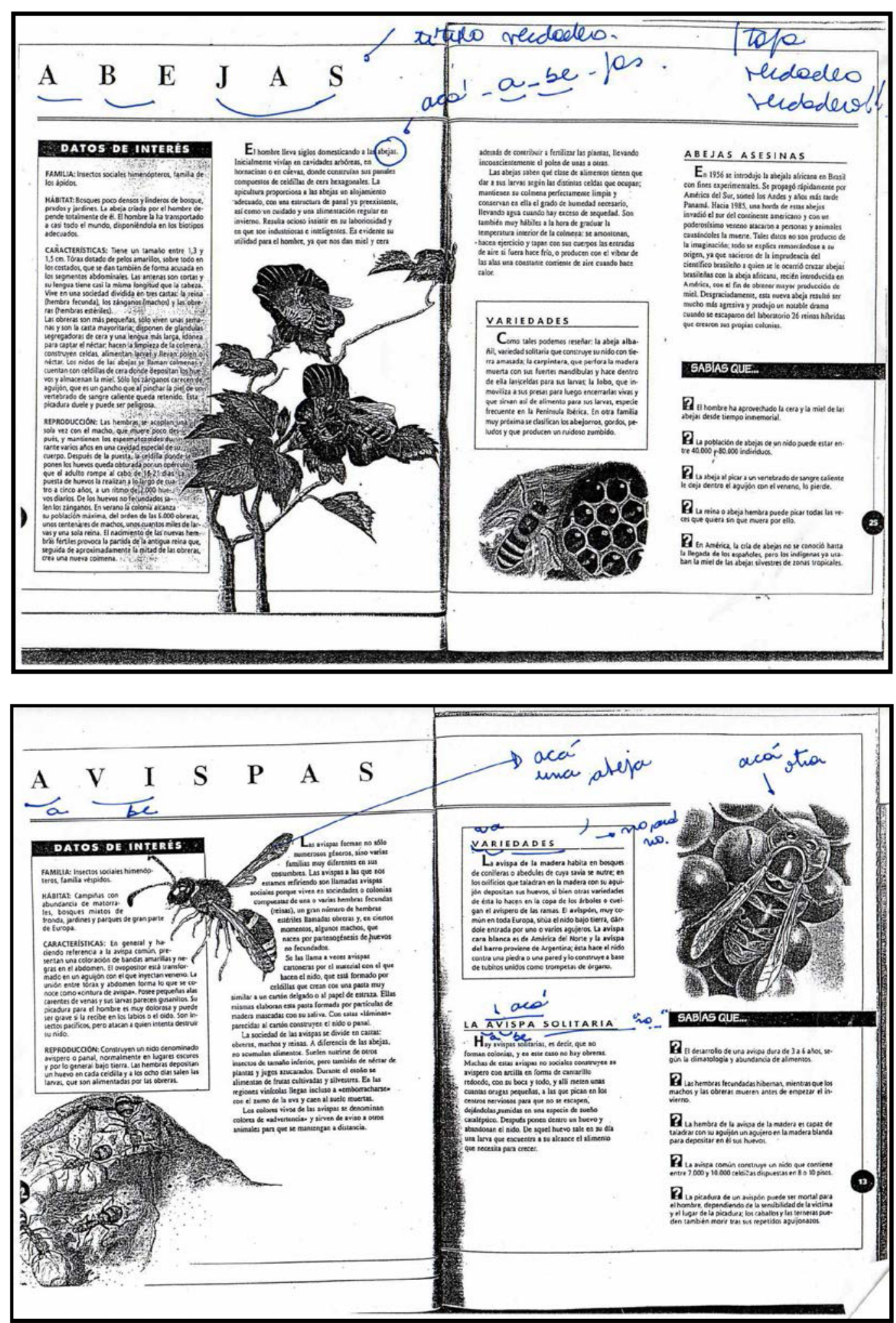